Nevada

Environmental

Restoration

Project

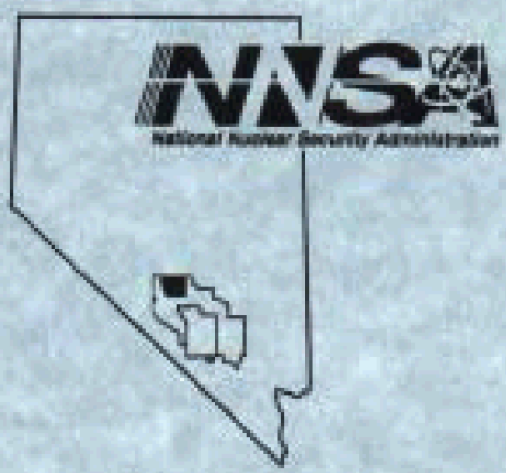

Closure Report for Corrective Action Unit 425: Area 9 Main Lake Construction Debris Disposal Area, Tonopah Test Range, Nevada

Controlled Copy No::

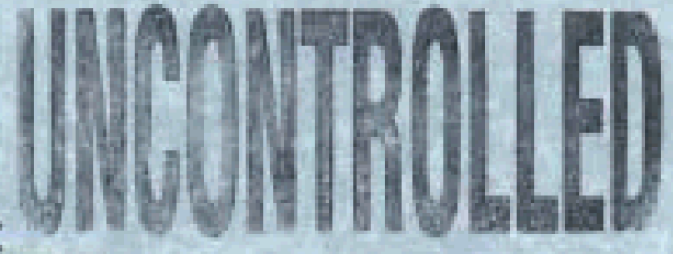

Revision: 0

February 2003

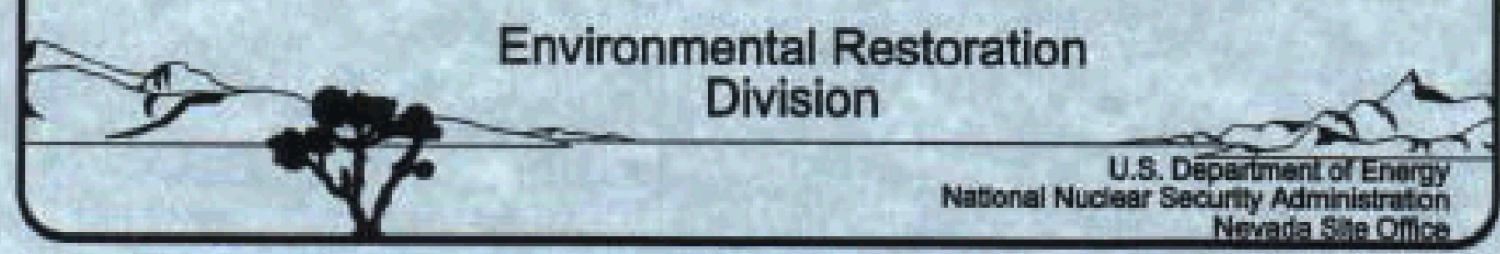




\section{DISCLAIMER STATEMENT}

Reference herein to any specifie commercial product, process, or service by trade name, trademark, manufaeturer, or otherwise, does not necessarily constitute or imply its endorsement, recommendation, or favoring by the U.S. Govemment or any agency thereof or its contractors or subcontraetors.

\section{AVAILABILITY STATEMENT}

Available for sale to the public from-

U.S. Department of Commerce

National Technieal Information Service

5285 Port Royal Road

Springfield, VA 22161-0002

Telephone: $800.553,6847$

Fax: $703,605,6900$

E-mail orders@ntis. fedworld.gov

Online ordering: http:/www ntis,gov/ordering htm

Available electronically at http $/ / w w w . d o e . g o v / b r i d g e$

Available for a processing fee to U.S. Department of Energy and its contractors, in paper, from-

US. Department of Energy

Office of Scientific and Technical Information

P.O. Box 62

Oak Ridge, TN 37831-0062

Telephone: 865.576 .8401

Fax: 865.576 .5728

E-maili reportsioadonis.osti.gov 


\title{
CLOSURE REPORT \\ FOR CORRECTIVE ACTION UNIT 425: \\ AREA 9 MAIN LAKE CONSTRUCTION DEBRIS DISPOSAL AREA, TONOPAH TEST RANGE, NEVADA
}

\author{
Prepared for: \\ U.S. Department of Energy \\ National Nuclear Security Administration \\ Nevada Site Office \\ Work Performed Under Contract No. DE-AC08-96NV11718
}

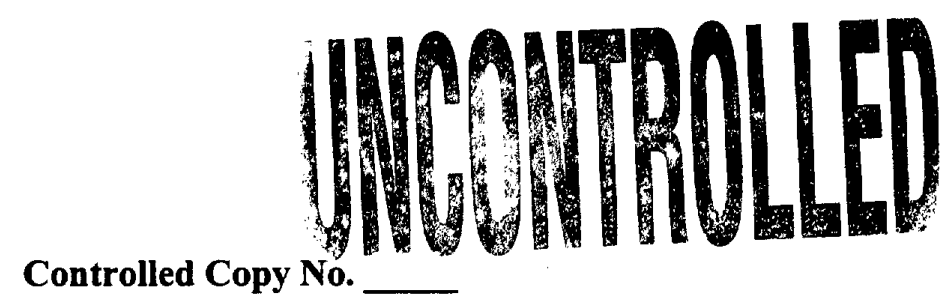

Revision: 0

February 2003 
THIS PAGE INTENTIONALLY LEFT BLANK 


\section{CLOSURE REPORT FOR CORRECTIVE ACTION UNIT 425: AREA 9 MAIN LAKE CONSTRUCTION DEBRIS DISPOSAL AREA, TONOPAH TEST RANGE, NEVADA}

\footnotetext{
Approved by: Temii Cabch $\ldots$

Date: $1.30-03$

Janet Appenzeller-Wing, Project Manager Industrial Sites Project

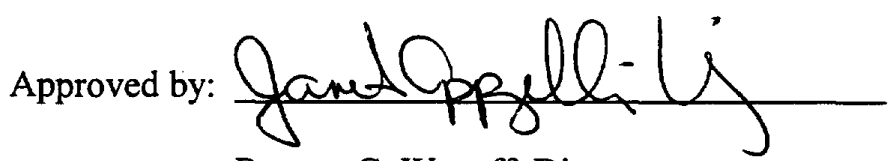

Date: $1 / 30 / 03$ funore C. Wycoff, Director

Environmental Restoration Division
} 
THIS PAGE INTENTIONALLY LEFT BLANK 


\section{TABLE OF CONTENTS}

ACRONYMS AND ABBREVIATIONS $\ldots \ldots \ldots \ldots \ldots \ldots \ldots \ldots \ldots \ldots \ldots$ vii

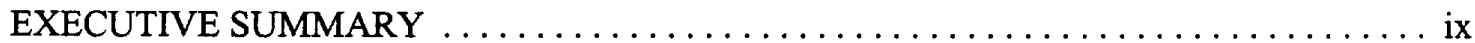

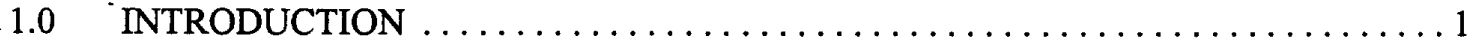

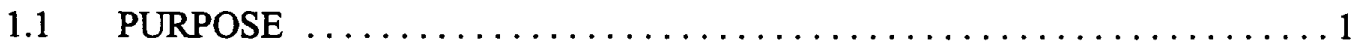

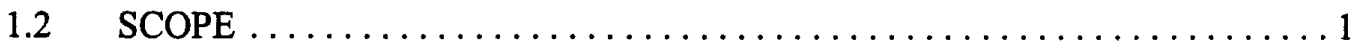

1.3 CLOSURE REPORT CONTENTS $\ldots \ldots \ldots \ldots \ldots \ldots \ldots \ldots \ldots \ldots \ldots$

1.3.1 Data Quality Objectives ......................... 5

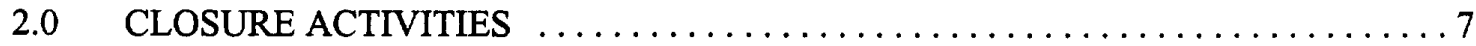

2.1 DESCRIPTION OF CORRECTIVE ACTION ACTIVITIES $\ldots \ldots \ldots \ldots \ldots 7$

2.1.1 Preplanning and Site Preparation ...................

2.1.2 CAS 09-08-001-TA09: Corrective Action Activities $\ldots . \ldots \ldots \ldots .7$

2.2 DEVIATIONS FROM SAFER PLAN AS APPROVED $\ldots \ldots \ldots \ldots \ldots \ldots 8$

2.3 CORRECTIVE ACTION SCHEDULE AS COMPLETED $\ldots \ldots \ldots \ldots \ldots \ldots 9$

$2.4 \quad$ SITE PLAN/SURVEY PLAN . . . . . . . . . . . . . . . . . . . . . 9

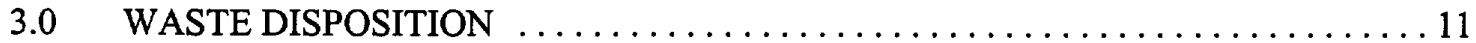

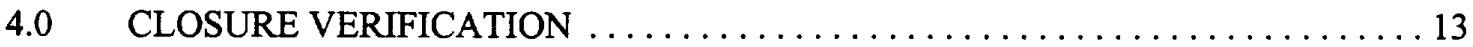

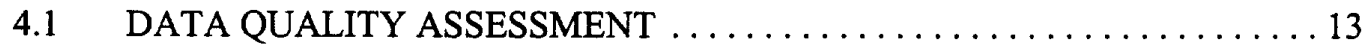

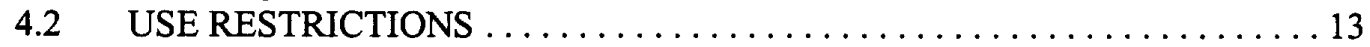

5.0 CONCLUSIONS AND RECOMMENDATIONS $\ldots \ldots \ldots \ldots \ldots \ldots \ldots \ldots \ldots \ldots$

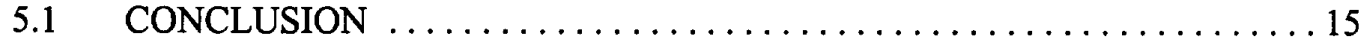

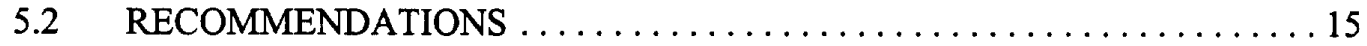

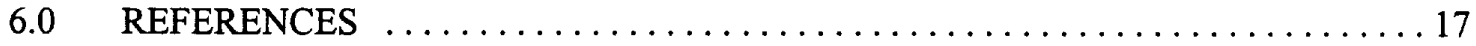

\section{FIGURES}

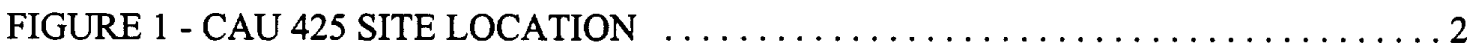

FIGURE 2 - CAS 09-08-001-TA09 SITE LOCATION $\ldots \ldots \ldots \ldots \ldots \ldots \ldots \ldots \ldots$

FIGURE 3 - CAU 425 CLOSURE ACTIVITIES AS COMPLETED $\ldots \ldots \ldots \ldots \ldots \ldots$ 


\section{TABLE OF CONTENTS (continued)}

\section{APPENDICES}

APPENDIX A - DATA QUALITY OBJECTIVES FOR CAU 425

APPENDIX B - WASTE TRACKING FORMS

APPENDIX C - RADIOLOGICAL SURVEY FORMS

APPENDIX D - WASTE DISPOSITION DOCUMENTATION

APPENDIX E - PHOTOGRAPHS OF CLOSURE ACTIVITIES

APPENDIX F - NEVADA DIVISION OF ENVIRONMENTAL PROTECTION DOCUMENT REVIEW SHEET

DISTRIBUTION LIST 


\section{ACRONYMS AND ABBREVIATIONS}

\begin{tabular}{|c|c|}
\hline $\mathrm{BN}$ & Bechtel Nevada \\
\hline CAS & Corrective Action Site \\
\hline $\mathrm{CAU}$ & Corrective Action Unit \\
\hline $\mathrm{COPC}^{-}$ & Contaminant of Potential Concern \\
\hline $\mathrm{CR}$ & Closure Report \\
\hline DOE & U.S. Department of Energy \\
\hline $\mathrm{DOE} / \mathrm{NV}$ & U.S. Department of Energy, Nevada Operations Office \\
\hline DU & Depleted Uranium \\
\hline DQO & Data Quality Objectives \\
\hline $\mathrm{ft}$ & foot(feet) \\
\hline $\mathrm{ft}^{3}$ & cubic feet \\
\hline FFACO & Federal Facility Agreement and Consent Order \\
\hline gal & gallon(s) \\
\hline L & Liter(s) \\
\hline LLW & Low Level Waste \\
\hline $\mathrm{m}$ & meter(s) \\
\hline $\mathrm{m}^{3}$ & cubic meter(s) \\
\hline NDEP & Nevada Division of Environmental Protection \\
\hline NNSA & U.S. Department of Energy, National Nuclear Security Administration \\
\hline NTS & Nevada Test Site \\
\hline RCT & Radiological Control Technician \\
\hline ROTC & Record of Technical Change \\
\hline RMA & Radiological Materials Area \\
\hline RWP & Radiological Work Permit \\
\hline SAFER & Streamlined Approach for Environmental Restoration \\
\hline TL & Technical Lead \\
\hline TTR & Tonopah Test Range \\
\hline USAF & U.S. Air Force \\
\hline $\mathrm{yd}^{3}$ & cubic yard(s) \\
\hline
\end{tabular}


CLOSURE REPORT - CAU 425

Section: Acronyms \& Abbrev.

Revision: 0

Date: February 2003

THIS PAGE INTENTIONALLY LEFT BLANK 


\section{EXECUTIVE SUMMARY}

Corrective Action Unit (CAU) 425 is located on the Tonopah Test Range, approximately 386 kilometers (240 miles) northwest of Las Vegas, Nevada. CAU 425 is listed in the Federal Facility Agreement and Consent Order (FFACO, 1996) and is comprised of one Corrective Action Site (CAS). CAS 09-08-001-TA09 consisted of a large pile of concrete rubble from the original Hard Target and construction debris associated with the Tornado Rocket Sled Tests.

CAU 425 was closed in accordance with the FFACO and the Nevada Division of Environmental Protection-approved Streamlined Approach for Environmental Restoration Plan for CAU 425: Area 9 Main Lake Construction Debris Disposal Area, Tonopah Test Range, Nevada (U.S. Department of Energy, Nevada Operations Office, 2002). CAU 425 was closed by implementing the following corrective actions:

The approved corrective action for this unit was clean closure. Closure activities included:

- Removal of all the debris from the site.

- Weighing each load of debris leaving the job site.

- Transporting the debris to the U.S. Air Force Construction Landfill for disposal.

- Placing the radioactive material in a U.S. Department of Transportation approved container for proper transport and disposal.

- Transporting the radioactive material to the Nevada Test Site for disposal.

- Regrading the job site to its approximate original contours/elevation. 
CLOSURE REPORT - CAU 425

Section: Executive Summary

Revision: 0

Date: February 2003

THIS PAGE INTENTIONALLY LEFT BLANK 


\subsection{INTRODUCTION}

This Closure Report (CR) documents the activities undertaken to close Corrective Action Unit (CAU) 425, Area 9 Main Lake Construction Debris Disposal Area according to the Federal Facility Agreement and Consent Order (FFACO) of 1996. CAU 425 closure was performed according to the Nevada Division of Environmental Protection (NDEP)-approved Streamlined Approach for Environmental Restoration (SAFER) Plan for CAU 425 (U.S. Department of Energy, Nevada Operations Office [DOE/NV], 2002). CAU 425 consists of one Corrective Action Site (CAS), 09-08-001-TA09: Area 9 Main Lake Construction Debris Disposal Area, Tonopah Test Range (TTR), Nevada. The site is located approximately 81 meters (m) (265 feet $[\mathrm{ft}]$ ) north of Edwards Freeway northeast of Main Lake on the TTR (Figure 1).

The Construction Debris Disposal Area was used to collect debris from various projects in and around Area 9. The site was composed of concrete slabs and metal rebar, wooden telephone poles from the early Tornado Rocket Sled Tests, and concrete rubble from the demolition of the Hard Target. It is estimated that the site contained approximately 2,280 cubic meters $\left(\mathrm{m}^{3}\right)$ (3,000 cubic yards $\left.\left[\mathrm{yd}^{3}\right]\right)$ of construction-related debris (Figure 2).

\subsection{PURPOSE}

The Construction Debris Disposal Site is identified as CAU 425 in the FFACO (FFACO, 1996). The purpose of this CR is to document that the closure of CAU 425 complied with all of the closure requirements detailed in the NDEP-approved SAFER Plan (DOE/NV, 2002).

\subsection{SCOPE}

The closure strategy for CAU 425 was specified in the NDEP-approved SAFER Plan for CAU 425 (DOE/NV, 2002). The implemented closure strategy consisted of the following activities.

- Loading all material present at the site into end dumps.

- Screening the material for radiation contamination during removal.

- Segregating Depleted Uranium (DU) fragments and DU-impacted debris/soil from nonimpacted debris/soil.

- Weighing each load of debris at the U.S. Air Force (USAF) TTR truck scales.

- Transporting debris to the USAF TTR Construction Landfill for disposal.

- Placing DU and DU-impacted debris/soil in a U.S. Department of Transportationapproved container for transport and disposal.

- Transporting the containerized DU from TTR to the Nevada Test Site (NTS) for disposal as low-level waste (LLW). 
CLOSURE REPORT - CAU 425

Section: Introduction

Revision: 0

Date: February 2003

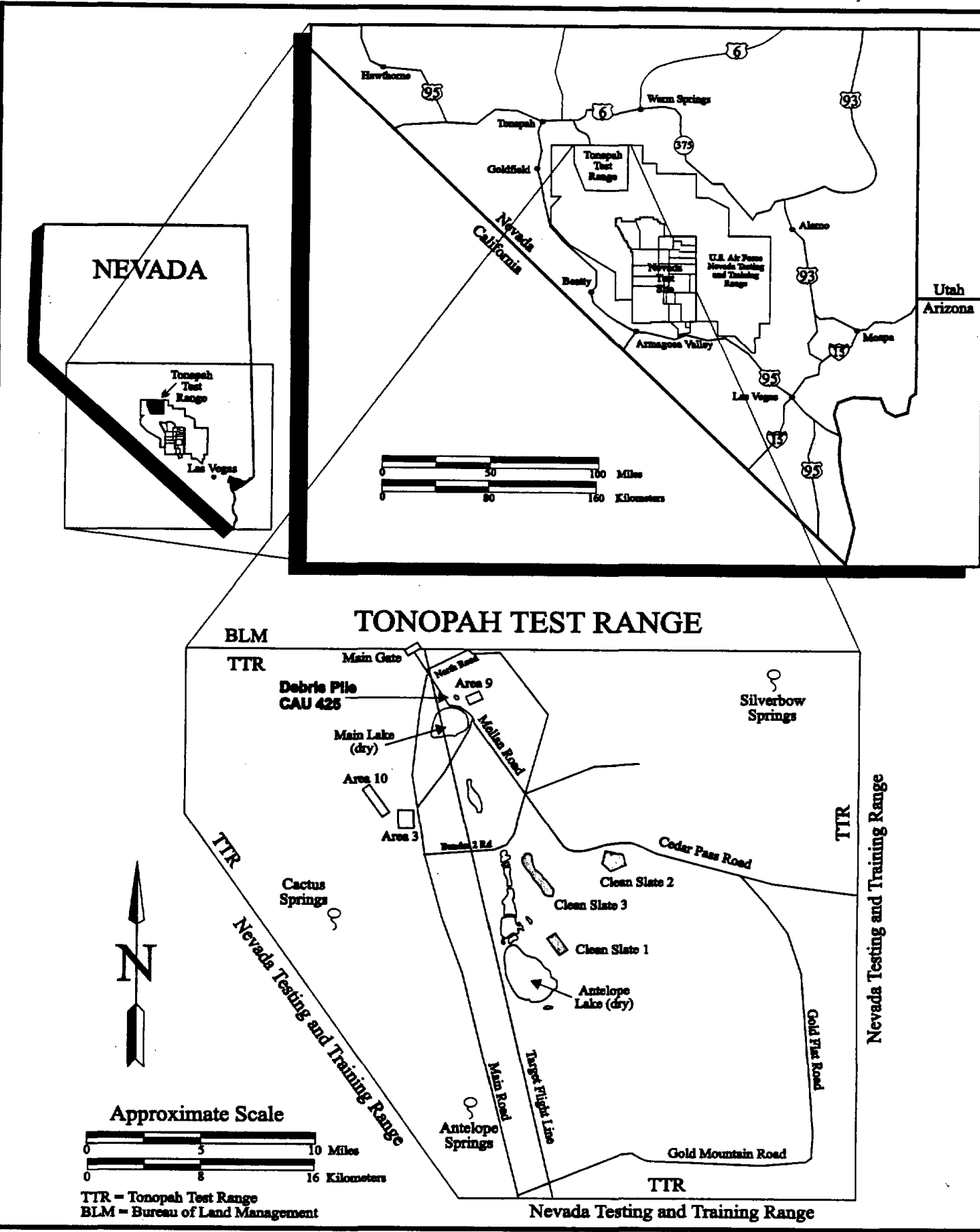

FIGURE 1

CAU 425 SITE LOCATION 


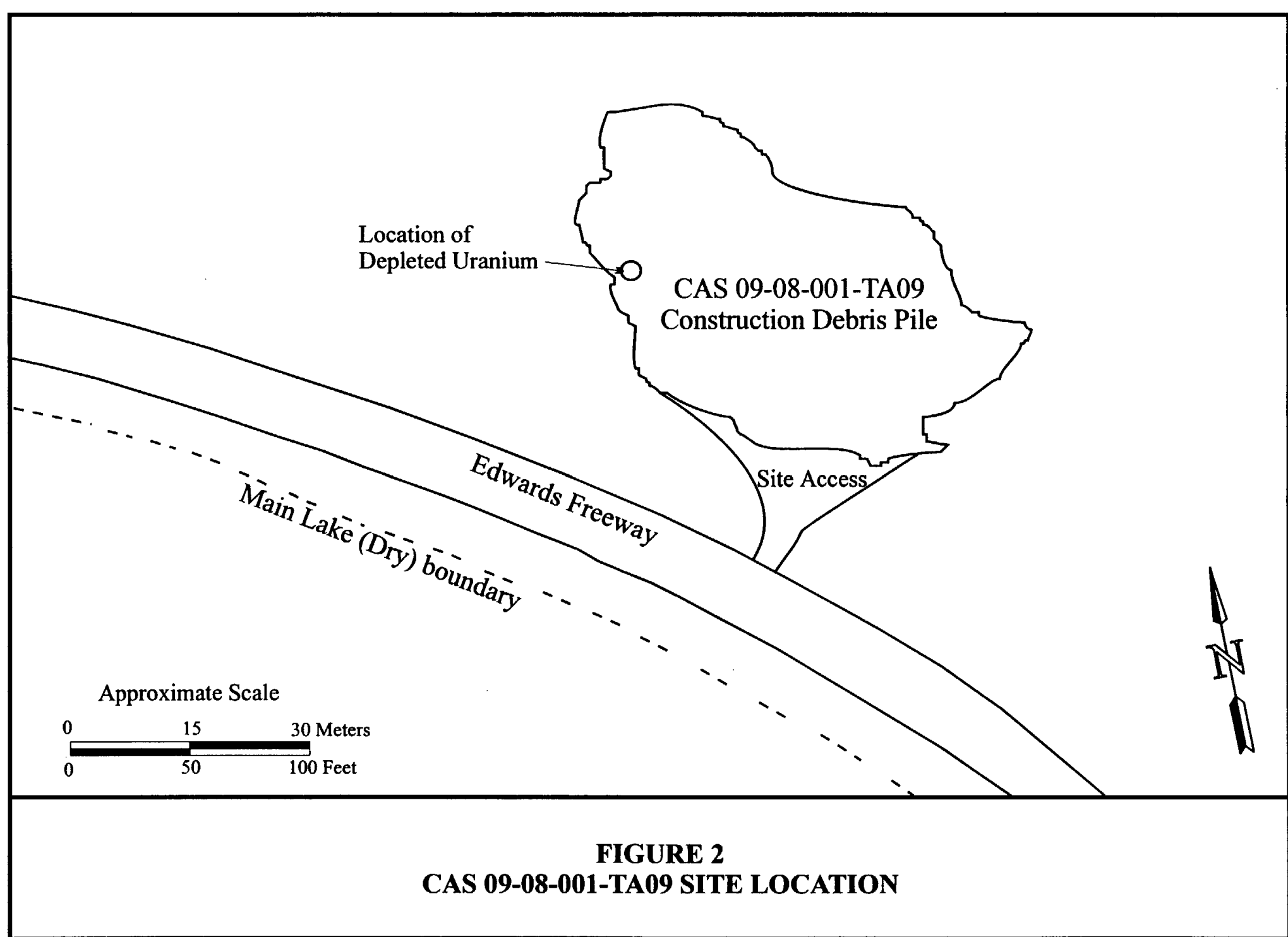




\subsection{CLOSURE REPORT CONTENTS}

This CR is divided into the following sections:

- Section 1.0-Introduction

- Section 2.0-Closure Activities

- Section 3.0-Waste Disposition

- Section 4.0-Closure Verification Results

- Section 5.0-Conclusions and Recommendations

- Section 6.0-References

The appendices included in this document are provided as follows:

- $\quad$ Appendix A-Data Quality Objectives (DQOs)

- Appendix B-Waste Tracking Forms

- $\quad$ Appendix C-Radiological Survey Forms

- Appendix D- Waste Disposition Documentation

- $\quad$ Appendix E-Photographs of Closure Activities

- Appendix F-Nevada Division of Environmental Protection Document Review Sheet

- Distribution List

This report was developed using information and guidance from the following documents:

- $\quad$ Streamlined Approach for Environmental Restoration Plan for Corrective Action Unit 425: Area 9 Main Lake Construction Debris Disposal Area. Tonopah Test Range, Nevada, Rev. 0, DOE/NV-813 (DOE/NV, 2002).

- Field Management Plan for Corrective Action Unit 425: Area 9 Main Lake Construction Debris Disposal Site, Nevada Test Site, Nevada (Bechtel Nevada [BN], 2002a).

- $\quad$ Site Specific Health \& Safety Plan for Corrective Action Unit 425: Area 9 Main Lake Construction Debris Disposal Site. Tonopah Test Range, Nevada (BN, 2002b). 


\subsubsection{Data Quality Objectives}

The data quality objectives (DQOs) used for clean closure of CAU 425 were based on historical data generated from preliminary site assessment activities.

The DQO's primary model, the most probable scenario for the conditions at CAU 425, stated that there are no contaminants of potential concern (COPCs) and no radiation above the freerelease criteria as specified in Table 4-2 of the Nevada Yucca Mountain Project Radiological Control Manual (DOE/NV, 2000). As detailed in Section 4.1, the alternative site conceptual model more closely resembled the actual site conditions since radiation greater than the freerelease level was found onsite during closure activities. 
CLOSURE REPORT - CAU 425

Section: Introduction

Revision: 0

Date: February 2003

THIS PAGE INTENTIONALLY LEFT BLANK 


\subsection{CLOSURE ACTIVITIES}

This section details the specific corrective action activities completed during the closure of CAU 425: Area 9 Main Lake Construction Debris Disposal Area.

\subsection{DESCRIPTION OF CORRECTIVE ACTION ACTIVITIES}

\subsubsection{Preplanning and Site Preparation}

Closure of CAU 425 was completed using the NDEP-approved SAFER Plan (DOE/NV, 2002). Prior to beginning site closure activities, the following pre-field activities were completed:

- Preparation of a National Environmental Policy Act documentation (checklist).

- Preparation of the Field Management Plan for Corrective Action Unit 425: Area 9 Main Lake Construction Debris Disposal Site, Tonopah Test Range, Nevada, (BN, 2002a).

- Preparation of the Site-Specific Health and Safety Plan for Closure Activities at Corrective Action Unit 425: Tonopah Test Range, Nevada, (BN, 2002b).

- Preparation of a U.S. DOE, National Nuclear Security Administration (NNSA)Nevada Operation Office Real Estate/Operations Permit.

- Preparation of BN Excavation and Penetration Permit.

The following is the scope of the closure actions implemented for CAU 425.

\subsubsection{CAS 09-08-001-TA09: Corrective Action Activities}

CAS 09-08-001-TA09 was clean closed by removing all of the construction debris from the site. Removal activities were initiated on the south side of the debris pile. Before each area of the debris was disturbed, a Radiological Control Technician (RCT) conducted a direct frisk of the debris about to be removed. A front-end loader was then used to collect a bucket of construction debris. The first bucket of debris for each end dump was directly frisked using a Ludlum 101 count rate meter with a pancake probe. The purpose of performing a direct frisk of the debris was to detect any elevated levels of radiation within the debris before it was placed into an end dump. The RCT reported the results of his survey to the Technical Lead (TL), who recorded the results on waste tracking forms (Appendix B). After the loader removed a bucket of debris from the pile, the RCT completed a direct frisk on the newly exposed face of the debris. This process was repeated until an end dump was filled with debris.

Once an end dump was full of construction debris, it was sent to the TTR Area 3 truck scale where the end dump was weighed. After the end dump was weighed, it dumped its load at the USAF TTR construction landfill and returned to the job site. Once the end dump arrived back at the job site, the TL recorded the weight of the load dumped, along with the trucking number, and 
time the end dump left, and returned to the job site. This process continued until all the construction debris and concrete rubble were removed from the site.

At the end of each day, the RCT collected swipes from all pieces of heavy equipment used that day. These swipes were surveyed using a Tennelec counter to check for any elevated levels of removable radiation contamination on the heavy equipment. Results of these surveys are included in Appendix C.

After approximately $2,140 \mathrm{~m}^{3}\left(2,800 \mathrm{yd}^{3}\right)$ of debris was removed, clean debris-free soil located on the north side of the site was used to return the site to its original grade and fill divots created during the debris removal process. Once all of the site activities were completed, a final radiological survey was conducted of all of the heavy equipment used, ensuring that they did not possess removable contamination above the free-release criteria. The heavy equipment was released from TTR after all swipes indicated that the equipment met the free-release criteria (DOE/NV, 2000).

On July 17,2002 , during the debris removal process, an area of elevated radiation was detected by the RCT in the southwestern portion of the work area (Figure 2). Results of the radiation survey are included in Appendix C. Upon closer inspection, the source of radiation was determined to be several small pieces of weathered DU. Immediately after the DU was detected, an area of approximately 20.9 square meters ( 25 square yards) was roped off around the DU and the area posted as a radiological materials area (RMA). Immediately, debris removal activities ceased inside the RMA. The RCT made a thorough investigation of the surrounding area for any additional DU. A Record of Technical Change (ROTC) to the SAFER plan and a Radiological Work Permit were prepared to allow the radiological material to be removed from the area and containerized for disposal. Work activities outside the RMA continued in the same manner as described earlier, until all that remained at the site was the roped-off RMA. Once the ROTC and RWP were approved, a long-handled shovel was used to remove any accessible pieces of DU and DU-impacted debris/soil. A rake was used to spread out all of the remaining debris within the RMA so the RCT could locate any remaining radiologically contaminated debris/soil. All of the DU-impacted debris/soil that was placed into the drum was found from within $3 \mathrm{~m}(10 \mathrm{ft})$ of the original piece of DU. A total of approximately $0.011 \mathrm{~m}^{3}$ ( 0.39 cubic feet $\left.\left[\mathrm{f}^{3}\right]\right)$ of DU and DU-impacted debris/soil was placed into a 208 liter [L] (55 gallon [gal]) drum. After site activities were completed, the drum was left at the site inside a roped and posted area for waste management to collect and transport to the NTS for disposal. The drum was removed from the site on September 27, 2002 and transported to the NTS for disposal. The drum was staged at the NTS Area 5 LLW storage pad and disposed of in the Area 5 LLW pits on January 22, 2003.

\subsection{DEVIATIONS FROM SAFER PLAN AS APPROVED}

The following deviation occurred from the approved scope of work as presented in the NDEP-approved SAFER Plan (DOE/NV, 2002).

During the debris removal activities, DU-impacted debris/soil was detected. The original SAFER Plan specified that if any elevated levels of radiation above the free-release criteria were 
discovered then debris removal activities in the immediate area would cease until a resolution had been agreed upon and a Record of Technical Change to the SAFER Plan had been approved by the NNSA Nevada Site Office and NDEP. On July 17, 2002, DU with radiation above the free-release criteria was discovered and debris removal activities in the southwest portion of the debris pile were suspended until a ROTC to the SAFER Plan was completed and approved. The ROTC and a RWP were prepared and approved and provided a safe and effective method for segregating, packaging and disposing of the DU and DU-impacted debris/soil without effecting the site closure work schedule.

\subsection{CORRECTIVE ACTION SCHEDULE AS COMPLETED}

The corrective action field activities began in July 2002 and were completed in August 2002. A corrective action schedule as completed is provided in Figure 3.

\subsection{SITE PLAN/SURVEY PLAN}

Because the CAU 425 was clean closed, verification data were not required for closure. Radiological survey results document the clean closure of DU-impacted debris/soil at the site. As-built drawings are not included in this $\mathrm{CR}$ because engineering construction was not required as part of this site closure. 
CLOSURE REPORT - CAU 425 Section: Closure Activities

Revision: 0

Date: February 2003

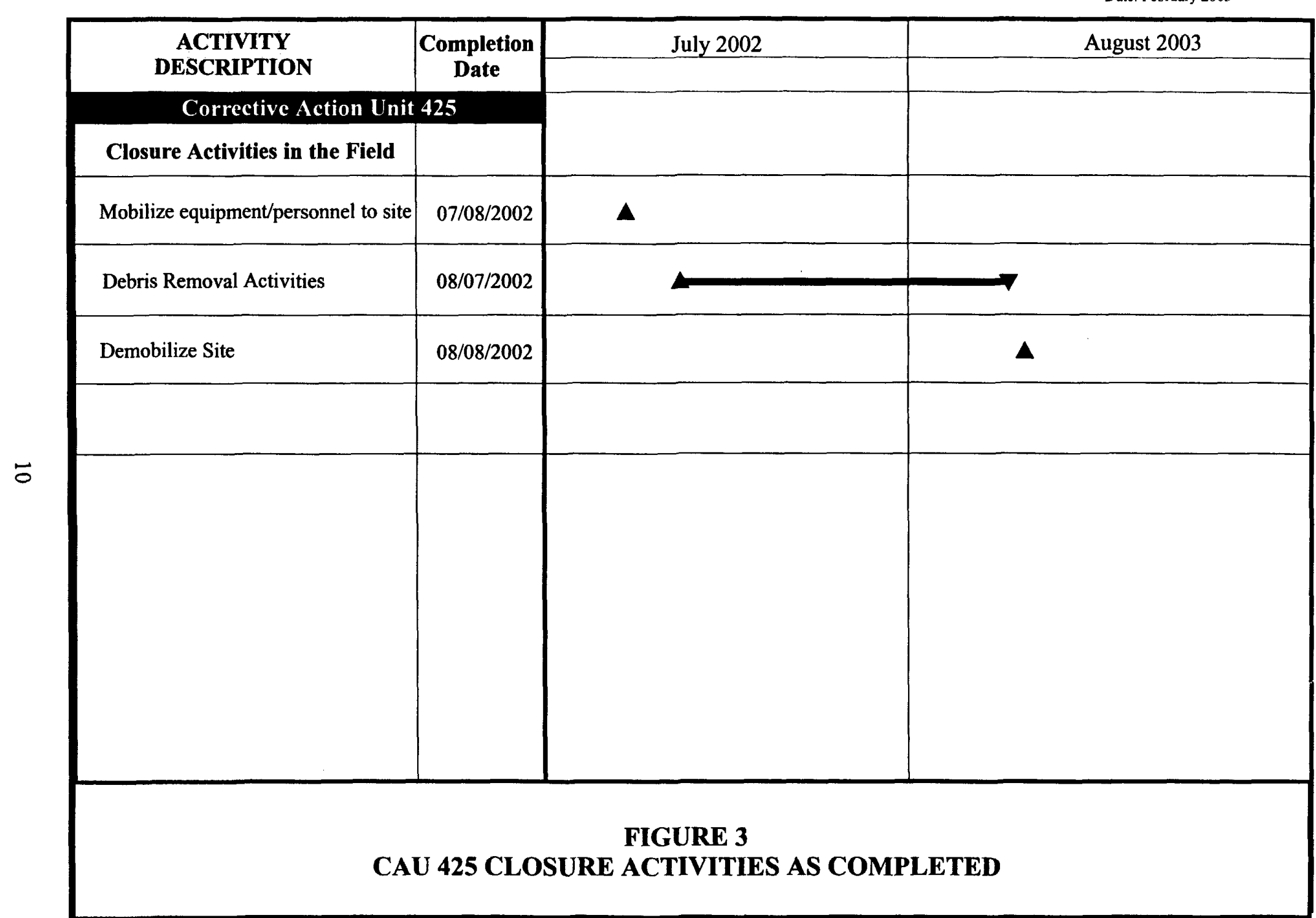




\subsection{WASTE DISPOSITION}

The wastes produced during closure of CAU 425 included sanitary waste (construction debris) and LLW (DU). All wastes were managed according to state and federal regulations, DOE orders, and $\mathrm{BN}$ procedures.

During closure activities at CAU 425 , approximately $2,140 \mathrm{~m}^{3}\left(2,800 \mathrm{yd}^{3}\right)$ of construction related debris was removed from the site and transported to the TTR USAF construction debris landfill. Documentation giving the contents, weight, and radiological survey results for each truck load of debris are provided in Appendices B and C.

During removal of the construction debris, pieces of inert ordnance were discovered within the debris pile. The USAF explosive ordnance disposal team was notified and brought to the site. BN was informed by the USAF verbally that the discovered ordnance was inert and that it could be treated as scrap metal. All of the inert ordnance was removed and disposed of in the TTR USAF construction landfill.

During the debris removal process approximately $0.011 \mathrm{~m}^{3}\left(0.39 \mathrm{ft}^{3}\right)$ of DU and DU-impacted debris/soil was segregated and packaged in a 208-L (55-gal) drum. The drum was transported to the NTS Area 5 LLW storage pad on September 27, 2002, where it is was staged pending disposal as LLW in one of the NTS Area 5 LLW pits. The drum was disposed of as LLW in the NTS Area 5 LLW pits on January 22, 2003. Waste disposition records on the disposal of the DU-impacted debris/soil are provided in Appendix D. 
CLOSURE REPORT - CAU 425

Section: Waste Disposition

Revision: 0

Date: February 2003

THIS PAGE INTENTIONALLY LEFT BLANK 


\subsection{CLOSURE VERIFICATION}

CAU 425 was remediated through clean closure. Site closure was verified visually to confirm that all construction debris was removed from the site. After the debris was removed from the site, clean soil was used to restore the site to the original grade. No samples were collected for closure verification because all the construction debris was removed from the site and there was no evidence of contamination in the underlying soil. Radiological field screening results were used to document clean closure of the DU-impacted debris/soil.

\subsection{DATA QUALITY ASSESSMENT}

CAU 425 closure activities were performed to the criteria specified in the DQOs presented in the NDEP-approved SAFER Plan (DOE/NV, 2002). The DQOs primary conceptual site model was considered the probable scenario for the conditions at CAS 09-08-001-TA09. The primary conceptual model assumed there were no COPCs and no elevated levels of radiation present above the free-release criteria present within the debris pile. Radiological surveys, site inspections, and process knowledge supported this model.

DU-impacted debris/soil was discovered in the debris pile after removing 25 loads of debris from the site. At this point it was clear the site more closely resembled the alternative conceptual site model as specified in the SAFER plan (DOE/NV, 2002). One of the conditions outlined in the alternative conceptual site model included the presence of radiological contamination onsite at screening levels greater than background levels. Since DU-impacted debris/soil with radiological levels above the free-release criteria was detected onsite, the alternative conceptual site model as specified in the DQOs applies. The alternative model was considered less likely than the conditions outlined in the primary model.

\subsection{USE RESTRICTIONS}

CAU 425 was clean closed and the land use is therefore unrestricted. Because CAU 425 has been clean closed, no land use restrictions or post-closure monitoring requirements are applicable. 
CLOSURE REPORT - CAU 425

Section: Closure Verification

Revision: 0

Date: February 2003

THIS PAGE INTENTIONALLY LEFT BLANK 


\subsection{CONCLUSIONS AND RECOMMENDATIONS}

\subsection{CONCLUSION}

CAU 425, Area 9 Main Lake Construction Debris Disposal Area, includes CAS 09-08-001-

TA09. The following closure activities were performed at the site.

- All construction debris was radiologically surveyed, weighed, and transported to the USAF construction debris landfill for disposal.

- DU and DU-impacted debris/soil were identified as LLW by conducting radiological surveys and segregated from sanitary waste.

- The LLW was packaged, transported to the NTS Area 5 LLW storage pad and disposed of on January 22, 2003.

- The site was restored to its approximate original grade upon completing site closure activities.

Clean closure was accomplished according to the NDEP-approved SAFER Plan

(DOE/NV, 2002).

\subsection{RECOMMENDATIONS}

Based on completion of site closure activities as documented by this $\mathrm{CR}$, it is requested that a notice of completion be provided by the NDEP for CAU 425 . Upon closure approval, CAU 425 will be promoted from Appendix III to Appendix IV of the FFACO (1996), "Closed Corrective Action Units." 
CLOSURE REPORT - CAU 425

Section: Conclusions \& Recom.

Revision: 0

Date: February 2003

THIS PAGE INTENTIONALLY LEFT BLANK 


\subsection{REFERENCES}

Bechtel Nevada. 2002a. Field Management Plan for Corrective Action Unit 425: Area 9 Main Lake Construction Debris Disposal Site, Nevada Test Site, Nevada, Las Vegas, NV.

Bechtel Nevada. 2002b. Site Specific Health \& Safety Plan for Corrective Action Unit 425: Area 9 Main Lake Construction Debris Disposal Site, Tonopah Test Range, Nevada Las Vegas, NV.

BN, see Bechtel Nevada.

DOE/NV, see U.S. Department of Energy, Nevada Operations Office.

FFACO, see Federal Facility Agreement and Consent Order.

Federal Facility Agreement and Consent Order. 1996 (as amended). Agreed to by the State of Nevada, U.S. Department of Energy, and U.S. Department of Defense.

U.S. Department of Energy, Nevada Operations Office. 2000. NV/YMP Radiological Control Manual, Rev. 4, DOE/NV/11718-079, Las Vegas, NV.

U.S. Department of Energy, Nevada Operations Office. 2002. Streamlined Approach for Environmental Restoration Plan for Corrective Action Unit 425: Area 9 Main Lake Construction Debris Disposal Area, Tonopah Test Range, Nevada, Rev. 0, DOE/NV--813, Las Vegas, NV. 
CLOSURE REPORT - CAU 425

Section: References

Revision: 0

Date: February 2003

THIS PAGE INTENTIONALLY LEFT BLANK 
CLOSURE REPORT - CAU 425

Section: Appendix A

Revision: 0

Date: February 2003

\section{APPENDIX A \\ DATA QUALITY OBJECTIVES FOR CAU 425*}

\footnotetext{
* As presented in the approved Streamlined Approach for Environmental Restoration Plan for Corrective Action Unit 425: Area 9 Main Lake Construction Debris Disposal Area, Tonopah Test Range, Nevada, April 2002.
} 
CLOSURE REPORT - CAU 425

Section: Appendix A

Revision: 0

Date: February 2003

THIS PAGE INTENTIONALLY LEFT BLANK 


\section{ACRONYMS AND ABBREVIATIONS}

$\begin{array}{ll}\text { BN } & \text { Bechtel Nevada } \\ \text { CAS } & \text { Corrective Action Site } \\ \text { CAU } & \text { Corrective Action Unit } \\ \text { COPC } & \text { Contaminant(s) of potential concern } \\ \text { DOE } & \text { U.S. Department of Energy } \\ \text { DOE } \mathrm{NV} & \text { U.S. Department of Energy, Nevada Operations Office } \\ \text { DQO } & \text { Data Quality Objective(s) } \\ \text { DU } & \text { Depleted uranium } \\ \text { EPA } & \text { U.S. Environmental Protection Agency } \\ \text { FFACO } & \text { Federal Facility Agreement and Consent Order } \\ \mathrm{ft} & \text { foot(feet) } \\ \mathrm{ft}^{2} & \text { square feet } \\ \mathrm{ft}^{3} & \text { cubic feet } \\ \text { IT } & \text { International Technology } \\ \mathrm{m} & \text { meter(s) } \\ \mathrm{m}^{2} & \text { square meters } \\ \mathrm{m}^{3} & \text { cubic meters } \\ \mathrm{NNSANSO} & \text { U.S. Department of Energy, National Nuclear Security Administration Nevada } \\ & \text { Site Office } \\ \mathrm{NDEP} & \text { Nevada Division of Environmental Protection } \\ \mathrm{SAFER} & \text { Streamlined Approach for Environmental Restoration } \\ \mathrm{TTR} & \text { Tonopah Test Range } \\ \mathrm{UXO} & \text { Unexploded ordnance } \\ \end{array}$


CLOSURE REPORT - CAU 425

Section: Appendix A

Revision: 0

Date: February 2003

THIS PAGE INTENTIONALLY LEFT BLANK 


\title{
APPENDIX A \\ DATA QUALITY OBJECTIVES FOR \\ CORRECTIVE ACTION UNIT 425: AREA 9 MAIN LAKE \\ CONSTRUCTION DEBRIS DISPOSAL AREA, TONOPAH TEST RANGE, NEVADA
}

\author{
Presentation of Known Data Related to Corrective Action Unit 425 \\ The information presented in this worksheet is based on historical data generated from \\ preliminary assessment activities for Corrective Action Unit (CAU) 425 at the Tonopah Test \\ Range (TTR). Data quality objective (DQO) worksheets follow the U.S. Environmental \\ Protection Agency (EPA) DQO guidance outline (EPA, 2000). The steps systematically build on \\ the data acquired during preliminary assessment work and background research. Copies of the \\ preliminary assessment work are retained in the project files. \\ Members of the Scoping Team:
}

1. U.S. Department of Energy, National Nuclear Security Agency Nevada Site Office (NNSANSO)

Janet Appenzeller-Wing

Kevin Cabble

2. Bechtel Nevada (BN)

Brad Jackson

Jeff Smith

Michael Kruzic

3. Nevada Division of Environmental Protection (NDEP)

Clem Goewert

4. International Technology (IT) Corporation

Jeff Johnson

Core Decision Team

Janet Appenzeller-Wing (NNSA/NSO)

Kevin Cabble (NNSA/NSO)

Brad Jackson (BN)

Primary Decision Makers

Janet Appenzeller- Wing (NNSANSO)

Kevin Cabble (NNSANSO) 


\subsection{PROBLEM STATEMENT}

\subsection{State the problem.}

CAU 425 is comprised of one Corrective Action Site (CAS): CAS 09-08-001-TA09, Construction Debris Disposal Area, TTR. In order to properly close this site, it must be determined if there is sufficient information to close this site under the Streamlined Approach to Environmental Restoration (SAFER) process.

\subsection{Summarize the problem - combine the relevant background information into a concise description of the problem to be resolved.}

\subsubsection{CAS 09-08-001-TA09, Construction Debris Disposal Area (TTR)}

CAS 09-08-001-TA09, Construction Debris Disposal, is located northeast of Main Lake approximately 81 meters $(\mathrm{m})$ (265 feet [ $\mathrm{ft}]$ ) north of Edwards Freeway on the TTR. Based on information obtained from site investigations, personal interviews and historical documentation, the site was used to collect debris from various projects in and around Area 9. This included concrete from the Hard Target and early Tornado Rocket sled tests from the early 1960s until approximately 1989 (Elliston, 1998; Kluesner, 2001). The Hard Target was a circular target used for weapon air drops. It was 30 centimeters (12 inches) thick and was composed of approximately 2,280 cubic meters $\left(\mathrm{m}^{3}\right)\left(3,000\right.$ cubic yards $\left.\left[\mathrm{yd}^{3}\right]\right)$ of concrete. The Hard Target was rebuilt in the 1970s and the debris from the original was disposed at the waste dump. The Tornado Rocket sled tests were performed in the early to mid 1970s. The tests were designed to simulate flying debris from a tornado. The tests consisted of telephone poles, portions of cars, and other nonhazardous materials, being slammed into concrete (West, 1993). The debris pile covers an area of approximately 2,323 square meters $\left(\mathrm{m}^{2}\right)\left(2,778\right.$ square feet $\left.\left[\mathrm{ft}^{2}\right]\right)$. The surface debris consists primarily of concrete slabs with metal infrastructures and other concrete rubble. Wood scraps, plastic pipes, and other miscellaneous items have also been identified in the debris pile. (IT, 2001; U. S. Department of Energy, Nevada Site Office [DOE/NV], 1996a; Kluesner, 2001). The site was identified on July 14, 1993 by an IT Corporation, Las Vegas Office field crew during a review of aerial photographs. It is unknown if anything of concern is buried within the piles of debris that is not visible at the surface.

Based on historical documents and interviews there may have been depleted uranium (DU) released onto the Hard Target during weapon drops. Process knowledge indicates that any released DU was removed from the pad after tests were completed. A radiological survey of the site was conducted in 2001 since most of the debris originated from the Hard Target. The results of the survey indicated no radiation levels above background (IT, 2001). Historical documentation also indicates that a small pile of inert unexploded ordnance (UXO) was removed from this site in March of 1995. All UXO that was visible appeared in one location of the debris pile and was placed on top of the debris pile or to the side of it. All UXO that was observed at the site was removed. UXO waste included several inert bombs and scrap metal/fragments. All UXO removed was determined to be inert or unfused (IT, 1995). 
CLOSURE REPORT - CAU 425

Section: Appendix A

Revision: 0

Date: February 2003

The CAU 425 site is located in Cactus Flat. Cactus Flat is an intermontane basin, typical of the Basin and Range Physiographic Province, surrounded by the Cactus Range to the southwest, the northern portion of Kawich Range to the east, and the Monitor Range to the north

(DOE/NV, 1994). Cactus Flat is made up of Quaternary-aged alluvium eroded from the surrounding volcanic highlands. The depth of the alluvium is unknown but exploratory drilling discovered the thickness to exceed $300 \mathrm{~m}(1,000 \mathrm{ft})$ (DOE/NV, 1996b). The alluvium layer is underlain by genetically related tuffs and lavas of the Thirsty Canyon Tuff unit, which can have a depth up to $152 \mathrm{~m}(500 \mathrm{ft})$ (DOE/NV, 1994). Beneath the Thirsty Canyon Tuff unit lie the rhyolitic tuffs of the Timber Mountain Tuff unit and the rhyolitic ash-fall and lavas of the Paintbrush Tuff unit. The Paintbrush unit is underlain by various layers of Miocene-aged volcanic lavas and tuffs and limestone and dolomite layers of various ages (U.S. Geological Survey, 1971). The depth to groundwater beneath Area 9 is estimated to be at a depth of $40 \mathrm{~m}$ $(131 \mathrm{ft})$ below the ground surface and the groundwater flow direction is generally to the southwest (DOE/NV, 1996a).

\subsection{DEVELOP/REFINE THE CONCEPTUAL MODEL}

Available information from which the conceptual model is based was derived from site process knowledge, historical background information, site analysis, and personnel interviews relative to the activities related to the debris site.

\subsection{Primary Model for CAS 09-08-001-TA09, Construction Debris Disposal Area (TTR)}

The primary model is considered the most probable scenario for current conditions at the CAU 425 site. The proposed activities are based on the assumption that there are no contaminants of potential concern (COPC) and no elevated levels of radiation present above free release criteria within the debris pile. Radiological surveys, site inspections, and process knowledge support this model. Almost all debris at the site is expected to be from the Hard Target since the approximate volumes at each are nearly identical.

\subsection{Alternate Model}

The conditions under the alternate model are considered less likely than the conditions outlined in the primary model. No information suggests that conditions outside the primary model are present. The alternate conceptual site model for CAS RG-24-001-RD24 is similar to the primary model with one or more of the following exceptions:

- Conditions outside the scope of work are encountered.

- Staining indicating the presence of COPCs on any debris in piles or in soil beneath piles is observed.

- Radiological screening yields results in excess of background.

- Non-construction-related debris is observed. 


\subsection{IDENTIFY THE DECISION (Select the appropriate decision for the current phase of the site assessment process)}

Development of a SAFER Plan will be prepared based on the currently available process knowledge, historical data, and survey data. The most probable closure decisions are identified below.

\subsection{CAS 09-08-001-TA09, Construction Debris Disposal Area (TTR)}

If no staining or other indications of the presence of COPC are visibly detected on any debris or in soil beneath debris piles, and no elevated levels of radioactivity are identified during closure activities, the site can be clean closed by excavation of the debris pile.

If any conditions outside of the scope of work are observed, then work will stop until an appropriate change of scope is identified and approved.

\subsection{IDENTIFY THE INPUTS TO THE DECISION}

\subsection{Identify the information inputs needed and resolve the decision.}

- Are forms of contamination present within the debris pile?

Process knowledge and data generated from previous characterization activities are adequate to verify that the primary model has no forms of contamination present within the debris pile. Constant visual inspection of the site during excavation will also be used to assure that no forms of contamination are present at the debris pile.

- Is depleted uranium present within the debris pile?

Process knowledge and data generated from previous characterization activities are adequate to verify the primary model, that there are no areas of radiation in excess of free release criteria are present within the debris pile. A radiological technician will be on site during the excavation process and will systematically screen, as described within the SAFER Plan, the debris before it is removed from the site to verify that there are no elevated levels of radiation.

- Is UXO present?

Process knowledge and data gathered from previous characterization activities are adequate to verify that all UXO in the primary model has been removed from the debris pile and all was unfused or inert. Constant visual inspection of the site will be conducted to assure that no UXO is present within the debris pile. 


\subsection{List types of contaminants of potential concern and affected media.}

There are no COPC expected to be present at this site.

4.3 Identify potential sampling approaches and appropriate analytical methods.

- Use existing characterization data and process knowledge to confirm or refute the conceptual model for the site.

- As part of DOE's interim action, a pile of inert UXO was removed from the site in 1995.

- There are not expected to be any forms of contamination found within the debris pile. For safety purposes constant visual inspection will be used to detect any forms of contamination during excavation activities.

- A radiological technician will be on-site during the excavation process and will systematically screen, as described in detail within the SAFER Plan, the debris before it is removed from the site to verify that levels of radiation do not exceed free release criteria.

\subsection{DEFINE THE BOUNDARIES OF THE STUDY}

\subsection{Define the geographic areas of the field investigation.}

\subsubsection{Define the geographic area within which all decisions must apply (in some cases} this may be defined by the Corrective Action Unit).

CAU 425 has been defined as the Area 9 Main Lake Construction Debris Disposal Area at the TTR. The study area specifically concerns the entire debris pile. The debris pile has an approximate area of $2,323\left(\mathrm{~m}^{2}\right)\left(2,778 \mathrm{yd}^{2}\right)$ and an approximate volume of $2,280 \mathrm{~m}^{3}\left(3,000 \mathrm{yd}^{3}\right)$. The site trends mostly east to. west, with debris piling to a height of $1.2 \mathrm{~m}(4 \mathrm{ft})$ on the eastern portion of the pile and $1.5 \mathrm{~m}(5 \mathrm{ft})$ on the southwestem portion of the pile.

\subsubsection{Specify the characteristics that define the population of interest.}

The population of interest is the entire construction debris pile and is well defined. The debris has been placed on the ground surface and is defined by the boundary between the concrete debris and the native ground interface.

\subsection{Define the time frame of the decision.}

\subsubsection{Determine the time frame to which the study data apply.}

The study data should be relevant with the length of time allowed for by the SAFER process under the Federal Facility Agreement and Consent Order (FFACO) agreement. 


\subsubsection{Determine when to collect data.}

Field activities (data collection) are scheduled to take place in fiscal year 2002 after approval of the final SAFER Plan. Data will be collected at times that meet the security and safety constraints of the TTR site, and at times when weather conditions that allow adequate site access and safe working conditions.

Radiological screening will be used to detect radiation above free release criteria before the debris is removed off-site. There will be no other data collection, unless staining or other evidence of the presence of COPC or potential environmental impact is visibly detected.

\subsubsection{Define relevant time constraints.}

- The final SAFER Plan is due to the U.S. Department of Energy, National Nuclear Security Agency Nevada Operations Office by April 30, 2002.

- Fieldwork is schęduled for late summer of 2002.

\subsection{Identify any practical constraints on data collection.}

1. Approval of the SAFER Plan and the DQO process by the NDEP.

2 Equipment access and mobility at the TTR.

3. Meteorological events that may impact fieldwork activities.

4. Health and safety of workers.

5. Operational/Security issues at the TTR.

\subsection{DEVELOP A DECISION RULE - DEFINE A LOGICAL BASIS FOR CHOOSING AMONG ALTERNATIVE ACTIONS}

\subsection{Specify the action level or preliminary action level for the decision.}

Sufficient process knowledge and site surveys exist to support the conceptual model. No forms of contamination are expected at this site. There will be continuous visual inspection of the site to ensure site safety. If any conditions outside the scope of work are observed, then work will stop until an appropriate change of scope is completed.

The site will be clean closed through the removal of all construction debris. Debris will be screened, loaded onto trucks, and transported to the U.S. Air Force TTR Construction Debris Landfill near Area 10. Each load will be weighed to document volume of debris removed. 


\subsection{OPTIMIZE THE DESIGN - OUTLINE A SAMPLING DESIGN, SPECIFYING THE OPERATIONAL DETAILS OF THE SAMPLING PLAN WHICH FALLS WITHIN THE PROJECTS CONSTRAINTS}

\subsection{Develop general sampling and analysis design alternatives.}

Material removed from the site will be screened for radioactivity above free release criteria. The work area will be continuously visually inspected for staining indicating the presence of COPCs and/or areas of environmental impact.

\subsection{Select the most resource-effective design that satisfies all of the DQOs.}

Excavate the debris in a manner that allows for constant visual inspection and radiation field screening of the debris pile in a systematic method, as described in detail within the SAFER Plan.

\subsection{Document the operational details and theoretical assumptions of the selected design in} the sampling and analysis plan.

There will be no sampling activities conducted at this site since no forms of contamination are expected. The radiological screening process for this site will be discussed in detail within the SAFER Plan. 
CLOSURE REPORT - CAU 425

Section: Appendix A

Revision: 0

Date: February 2003

THIS PAGE INTENTIONALLY LEFT BLANK

A-8 


\section{REFERENCES}

DOE/NV, see U.S. Department of Energy, Nevada Operations Office.

Elliston, J., Westinghouse. 1998. Record of interview with E. Dille' concerning Environmental Restoration sites at the Tonopah Test Range, 3 March. IT, Las Vegas, NV.

IT, see IT Corporation.

IT Corporation. 1995. "Record of Technical Change for Unexploded Ordnance Removal," 17 March. Las Vegas, NV.

IT Corporation. 2001. Radiological Survey Form. 21 February. Prepared by S. Wyler, IT, Las Vegas, NV.

Kluesner, B., Sandia National Laboratories. 2001. Record of interview with J. Markowsky regarding Tonopah Test Range sites, 20 February. IT, Las Vegas, NV.

U.S. Department of Energy, Nevada Operations Office. 1994. Resource Conservation Recovery Act Facility Investigation Work Plan, Volume 1, UC-70, May. Las Vegas, NV.

U.S. Department of Energy, Nevada Operations Office. 1996a. Corrective Action Unit Work Plan, July. Las Vegas, NV.

U.S. Department of Energy. Nevada Operations Office. 1996b. Final Environmental Impact Statement for the Nevada Test Site and Off-Site Locations in the State of Nevada, DOE/EIS 0243. Las Vegas, NV.

U.S. Geological Survey. 1971. Geology of Northern Nellis Air Force Base Bombing and Gunnery Range, Nye County, Nevada. Prepared by Ekren E.B., R.E. Anderson, C.L. Rogers, and D.C. Noble, for the U.S. Atomic Energy Commission. USGS Professional Paper 651, Government Printing Office, Washington, D.C.

U.S. Environmental Protection Agency. 2000. Guidance for the Data Quality Objective Process, EPA QA/G-4, Washington, D.C.

West, G., Sandia National Laboratories. 1993. Record of interview with P. Karas and R. Dubiskas regarding environmental restoration sites at Tonopah Test Range, 8 June. IT Las Vegas, NV. 
CLOSURE REPORT - CAU 425

Section: Appendix A

Revision: 0

Date: February 2003

THIS PAGE INTENTIONALLY LEFT BLANK 
CLOSURE REPORT - CAU 425

Section: Appendix B

Revision: 0

Date: February 2003

\section{APPENDIX B}

\section{WASTE TRACKING FORMS}


CLOSURE REPORT - CAU 425

Section: Appendix B

Revision: 0

Date: February 2003

THIS PAGE INTENTIONALLY LEFT BLANK 


\section{Bachtol Novada}

Environmental Restoration

\section{CAU 425 Waste Tracking Form}

\begin{tabular}{|c|c|c|c|c|c|c|c|c|}
\hline Date & $\begin{array}{c}\text { Truck } \\
\text { Number }\end{array}$ & $\begin{array}{c}\text { Truck } \\
\text { Arrival } \\
\text { Time } \\
\end{array}$ & $\begin{array}{l}\text { Site Grid } \\
\text { Location } \\
\end{array}$ & $\begin{array}{c}\text { Waste } \\
\text { Description }\end{array}$ & $\begin{array}{l}\text { Rad Screening } \\
\text { Results (unit?) }\end{array}$ & Observations & Waste Weight & $\begin{array}{l}\text { Departure } \\
\text { Time }\end{array}$ \\
\hline $7-11-02$ & $1-1$ & $16: 47$ & $A-4$ & $\begin{array}{l}\text { Concrete } \\
\text { Rubble }\end{array}$ & $\begin{array}{l}10-15 \mathrm{MR} / \mathrm{hr} \\
120-150 \mathrm{cpm}\end{array}$ & None & $51,716 \mathrm{lbs}$ & $15: 29$ \\
\hline $\begin{array}{r}7-11.02 \\
+7-15.02 \\
\end{array}$ & $2-2$ & $\begin{array}{l}13: 00 \\
7-15 \cdot 02\end{array}$ & $B-4$ & $\begin{array}{l}\text { Concrere } \\
\text { Rubble }\end{array}$ & $\begin{array}{l}10-15 \mathrm{MR} / \mathrm{hr} \\
120-150 \mathrm{cPm}\end{array}$ & None & 64,880165 & $\begin{array}{l}10: 55 \\
7-15-02\end{array}$ \\
\hline $\begin{array}{r}7-11-02 \\
+\quad 7-15-02 \\
\end{array}$ & $3-3$ & $\begin{array}{l}13: 00 \\
7-15-02\end{array}$ & $B-4$ & $\begin{array}{l}\text { Concrete } \\
\text { Rubble }\end{array}$ & $\begin{array}{l}10-15 \mathrm{mR} / \mathrm{hr} \\
120-150 \mathrm{cPm}\end{array}$ & None & $50,460 \mathrm{lss}$ & $\begin{array}{r}10: 55 \\
7-15.02\end{array}$ \\
\hline $7-15-02$ & $3-4$ & $14: 30$ & $\begin{array}{l}B-4 \\
A-3\end{array}$ & $\begin{array}{l}\text { Concretc Rubble } \\
\text { Concrete slabs } \\
\text { w/rebar }\end{array}$ & $\begin{array}{l}10-15 \mu \mathrm{r} / \mathrm{hr} \\
120-150 \mathrm{cpm}\end{array}$ & None & $24,46016 s$ & $13: 30$ \\
\hline $7-15-02$ & $2-5$ & $14: 55$ & $\begin{array}{c}B-4 \\
A-3\end{array}$ & $\begin{array}{l}\text { Concrete Rubble } \\
\text { Concrete Slabs } \\
\text { w/rebar }\end{array}$ & $\begin{array}{l}10-15 \mathrm{MR} / \mathrm{hr} \\
120-150 \mathrm{cpm}\end{array}$ & None & 29,100165 & $13: 45$ \\
\hline $7-15-02$ & $3-6$ & $15: 40$ & $\begin{array}{c}B-4 \\
+ \\
A-3\end{array}$ & $\begin{array}{l}\text { Concrete Rublle } \\
\text { Concrete Slabs } \\
\text { w/rebar }\end{array}$ & $\begin{array}{l}10-15 \mathrm{MR} / \mathrm{hs} \\
120-150 \mathrm{cpm}\end{array}$ & None & $34,780 \mathrm{ks}$ & $14: 47$ \\
\hline $7-15-02$ & $2-7$ & $16: 08$ & $\begin{array}{c}A-5 \\
+ \\
A-3 \\
\end{array}$ & $\begin{array}{l}\text { Concrete Rublle } \\
\text { Concrete slabs } \\
\text { w/ rebar }\end{array}$ & $\begin{array}{l}10-15 \mathrm{MR} / \mathrm{hr} \\
120-150 \mathrm{cpm}\end{array}$ & $\begin{array}{l}\text { Some rusted } \\
\text { metal pieces } \\
\text {-remeved }\end{array}$ & $39,3801 \mathrm{bs}$ & $15: 10$ \\
\hline $\begin{array}{c}7-15-02 \\
+ \\
7-16-02 \\
\end{array}$ & $3-8$ & $9: 50$ & $\begin{array}{l}A-5 \\
A-3 \\
B-5 \\
\end{array}$ & $\begin{array}{c}\text { Concrere Rublle } \\
\text { Concrete Siabs } \\
\text { w/rebar }\end{array}$ & $\begin{array}{l}10-15 \mathrm{mR} / \mathrm{hr} \\
120-150 \mathrm{~cm}\end{array}$ & No.ne & 36,560165 & $\begin{array}{c}8: 35 \\
7-16-02 \\
\end{array}$ \\
\hline $\begin{array}{c}7-15-02 \\
+ \\
7-16-02\end{array}$ & $2-9$ & $9: 40$ & $A-3$ & $\begin{array}{c}\text { Cancrete slabs } \\
w / r e b a r\end{array}$ & $\begin{array}{l}10-15 \mathrm{MR} / \mathrm{hr} \\
120-150 \mathrm{cPm}\end{array}$ & $\begin{array}{l}\text { ioose pieces } \\
\text { of rebar } \\
\text { - remoued }\end{array}$ & $39.960 \mathrm{l} / \mathrm{ss}$ & $\begin{array}{c}8: 40 \\
7-16-02 \\
\end{array}$ \\
\hline
\end{tabular}

Name: Michael R. Krazic Date: $7-16-0 z$

Signature: 


\section{Bachtal Movada}

Environmental Restoration

CAU 425 Waste Tracking Form

\begin{tabular}{|c|c|c|c|c|c|c|c|c|}
\hline Date & $\begin{array}{c}\text { Truck } \\
\text { Number }\end{array}$ & $\begin{array}{c}\text { Truck } \\
\text { Arrival } \\
\text { Time }\end{array}$ & $\begin{array}{l}\text { Site Grid } \\
\text { Location }\end{array}$ & $\begin{array}{c}\text { Waste } \\
\text { Description }\end{array}$ & $\begin{array}{l}\text { Rad Screening } \\
\text { Results (unit?) }\end{array}$ & Observations & Waste Weight & $\begin{array}{l}\text { Departure } \\
\text { Time }\end{array}$ \\
\hline $7-16-02$ & $3-10$ & $11: 27$ & $\begin{array}{l}A-3 \\
A-5 \\
B-5\end{array}$ & $\begin{array}{l}\text { Concrete Rubble } \\
\text { concrete slabs } \\
\text { w/rebar }\end{array}$ & $\begin{array}{l}10-15 \mathrm{~m} / \mathrm{L}_{\mathrm{Ir}} \\
120-150 \mathrm{cpm}\end{array}$ & $\begin{array}{l}\text { woose metal } \\
\text { w/in debris } \\
\text { - remoued }\end{array}$ & 39,520165 & $10: 32$ \\
\hline $7-16-0.2$ & $2-11$ & $11: 17$ & $\begin{array}{l}A-3 \\
A-5 \\
B-5\end{array}$ & $\begin{array}{l}\text { Concrete Rubble } \\
\text { Concrete slabs } \\
\text { W/rebar }\end{array}$ & $\begin{array}{l}10-15 \mu r / h r \\
120-150 \mathrm{cPm}\end{array}$ & $\begin{array}{l}\text { Loose metal } \\
\text { wlin debris } \\
\text {-removed }\end{array}$ & $.58,36016 \mathrm{~s}$ & $10: 15$ \\
\hline $7-16-02$ & $2-12$ & $13: 30$ & $\begin{array}{l}A-3 \\
A-5 \\
B-5\end{array}$ & $\begin{array}{l}\text { Concrete Rubble } \\
\text { Concrete slabs } \\
\text { w/reber }\end{array}$ & $\begin{array}{l}10-15 \mathrm{mR} / \mathrm{hr} \\
120-150 \mathrm{cpm}\end{array}$ & $\begin{array}{l}\text { Loose metal } \\
\text { wlin deloris } \\
\text { - remoued }\end{array}$ & $45,840 \mathrm{lbs}$ & $\begin{array}{l}11: 45 \\
w / 10 n c h\end{array}$ \\
\hline $7-16-0 z$ & $3-13$ & $13: 37$ & $\begin{array}{l}A-2 \\
B-5\end{array}$ & $\begin{array}{l}\text { Concrete Rubble } \\
\text { Some soil }\end{array}$ & $\begin{array}{l}10-15 \mathrm{MR} / \mathrm{hr} \\
120-150 \mathrm{cpin}\end{array}$ & None & $48,82016 \mathrm{~s}$ & $\begin{array}{r}11: 45 \\
\text { w/ lonch } \\
\end{array}$ \\
\hline $7-16-02$ & $2-14$ & $14: 45$ & $\begin{array}{l}A-2 \\
B-5\end{array}$ & $\begin{array}{l}\text { Conctete Rubble } \\
\text { some s.: }\end{array}$ & $\begin{array}{l}10-15 \mathrm{MR} / \mathrm{hr} \\
120-150 \mathrm{cpm}\end{array}$ & Norte & $46,58816 \mathrm{~s}$ & $13: 45$ \\
\hline $7-16-02$ & $3-15$ & $14: 55$ & $\begin{array}{l}A-3 \\
B-5\end{array}$ & $\begin{array}{l}\text { Concrete Rubble } \\
\text { Concrete Slabs } \\
\text { w/ rebar }\end{array}$ & $\begin{array}{l}10-15 \mathrm{MR} / \mathrm{hr} \\
120-150 \mathrm{cpms}\end{array}$ & $\begin{array}{l}\text { Loose metal } \\
\text { wlin debris. } \\
\text { - remoued }\end{array}$ & $43,960 \mathrm{lbs}$ & $14: 14$ \\
\hline $7 \cdot 16-02$ & $1-16$ & $15: 47$ & $\begin{array}{l}B-4 \\
B-5\end{array}$ & Concrete Rubble & $\begin{array}{l}10-15 \mathrm{MR} / \mathrm{hr} \\
120-150 \mathrm{cpm}\end{array}$ & None & 26,22016 & $14: 43$ \\
\hline $7-16-02$ & $2-1 ?$ & $16: 32$ & $\begin{array}{l}A-2 \\
B-5\end{array}$ & $\begin{array}{c}\text { Concrete Rublle } \\
\text { Concrete slabs } \\
\text { w/rebar }\end{array}$ & $\begin{array}{l}10-15 \mathrm{mR} / \mathrm{hr} \\
120-150 \mathrm{cfm}\end{array}$ & $\begin{array}{l}\text { scrap metal } \\
\text { wlin dabris } \\
\text { - remoued }\end{array}$ & $53,19016 \mathrm{~s}$ & $\begin{array}{r}\text { J } 5: 00 \\
\text { w/gis Fill }\end{array}$ \\
\hline $7-16-02$ & $3-18$ & $16: 30$ & $\begin{array}{l}A-2 \\
B-3\end{array}$ & $\begin{array}{l}\text { Concrete Rublle } \\
\text { Koncrete slabs } \\
\text { w/rebar }\end{array}$ & $\begin{array}{l}10-15 \mathrm{MR} / \mathrm{h}- \\
120-150<\mathrm{pm}\end{array}$ & $\begin{array}{l}\text { scrap metal } \\
\text { w/in debris } \\
\text {-remoued }\end{array}$ & $44,320 \mathrm{lbs}$ & $\begin{array}{l}15: 15 \\
\text { w/gas } F: 11\end{array}$ \\
\hline
\end{tabular}

Name:

Date: $7 \div 16-02$

Signature:

hatel kíruzic 


\section{Bechtel Novada}

Environmental Restoration

\section{CAU 425 Waste Tracking Form}

\begin{tabular}{|c|c|c|c|c|c|c|c|c|}
\hline Date & $\begin{array}{c}\text { Truck } \\
\text { Number }\end{array}$ & $\begin{array}{c}\text { Truck } \\
\text { Arrival } \\
\text { Time } \\
\end{array}$ & $\begin{array}{l}\text { Site Grid } \\
\text { Location } \\
\end{array}$ & $\begin{array}{c}\text { Waste } \\
\text { Description }\end{array}$ & $\begin{array}{l}\text { Rad Screening } \\
\text { Results (unit?) }\end{array}$ & Observations & Waste Weight & $\begin{array}{l}\text { Departure } \\
\text { i Time }\end{array}$ \\
\hline $7-16-02$ & $1-19$ & $17: 00$ & $A-2$ & $\begin{array}{l}\text { Concrete Rubble } \\
\text { Concrete slabs } \\
\text { w/re har } \\
\text { woud telephare pole }\end{array}$ & $\begin{array}{l}10-15 \mathrm{MR} / \mathrm{hr} \\
120-150 \mathrm{cps}\end{array}$ & $\begin{array}{l}\text { Contained } \\
\text { wood and } \\
\text { soine re mounble } \\
\text { metal }\end{array}$ & $38,930 \mathrm{ltbs}$ & $16: 00$ \\
\hline $7-17-02$ & $3-20$ & $8: 45$ & $\begin{array}{l}A-2 \\
B-5\end{array}$ & $\begin{array}{l}\text { Concrete Rubble } \\
\text { Concrete Slabs } \\
\text { wirebar }\end{array}$ & $\begin{array}{l}10-15 \mathrm{MR} / \mathrm{hr} \\
120-150 \mathrm{cmm}\end{array}$ & $\begin{array}{l}\text { some loose } \\
\text { metal-remoued }\end{array}$ & $41.78016 \mathrm{~s}$ & $7: 52$ \\
\hline $7-17-02$ & $1-22$ & $9: 3.2$ & $\begin{array}{l}A-2 \\
B-5 \\
B-6\end{array}$ & $\begin{array}{c}\text { Concrete Rubble } \\
\text { Concrete Slabs } \\
\text { w/ rebar }\end{array}$ & $\begin{array}{l}10-15 \mathrm{mR} / \mathrm{hr} \\
120-150 \mathrm{cmm}\end{array}$ & $\begin{array}{l}\text { some loose } \\
\text { metal } \\
\text { - removed }\end{array}$ & $43,02016 \mathrm{~s}$ & $8: 35$ \\
\hline $7-17-02$ & $3-23$ & $10: 00$ & $\begin{array}{l}A-2 \\
B-5 \\
B-6\end{array}$ & $\begin{array}{l}\text { Concrete Rublle } \\
\text { Concrete slabs } \\
\text { wrrebar } \\
\text { largecencrete pylon } \\
\text { soine weod }\end{array}$ & $\begin{array}{l}10-15 \mu R / \mathrm{hr} \\
120-150 \mathrm{crm}\end{array}$ & $\begin{array}{l}\text { Some loose } \\
\text { matal } \\
\text { - remoued }\end{array}$ & $40.88016 \mathrm{~s}$ & $9: 06$ \\
\hline $7-17-02$ & $1-25$ & $10: 44$ & $\begin{array}{l}A-2 \\
B-5\end{array}$ & $\begin{array}{l}\text { Concrete Rubble } \\
\text { Concrere Slabs } \\
\text { w/retar } \\
\text { Concrete Filled twbe }\end{array}$ & $\begin{array}{l}10-15 \mathrm{MR} / \mathrm{hr} \\
120-150 \mathrm{cpin}\end{array}$ & $\begin{array}{l}\text { some loose } \\
\text { metal } \\
\text { - removed }\end{array}$ & $42,1001 \mathrm{ls}$ & $4: 50$ \\
\hline $7-17-02$ & $3-26$ & $11: 08$ & $B-5$ & Concrete Rubble & $\begin{array}{l}10-15 \mathrm{\mu R} / \mathrm{hr} \\
130-150 \mathrm{cpm}\end{array}$ & None. & $46,080^{\circ} \mathrm{lbs}$ & $10: 14$ \\
\hline $7-12-02$ & $2-27$ & $11: 30$ & $\begin{array}{l}B-4 \\
B-5\end{array}$ & Concrete Rublle & $\begin{array}{l}10-15 \mu \mathrm{R} / \mathrm{hr} \\
120-150 \mathrm{cPm}\end{array}$ & None & $43,260 \mathrm{lbs}$ & $10: 40$ \\
\hline
\end{tabular}

Name: Nichael R. Kruzic

Date: $2-12-02$

Signature 


\section{Bechtel Nevada}

Environmental Restoration

\section{CAU 425 Waste Tracking Form}

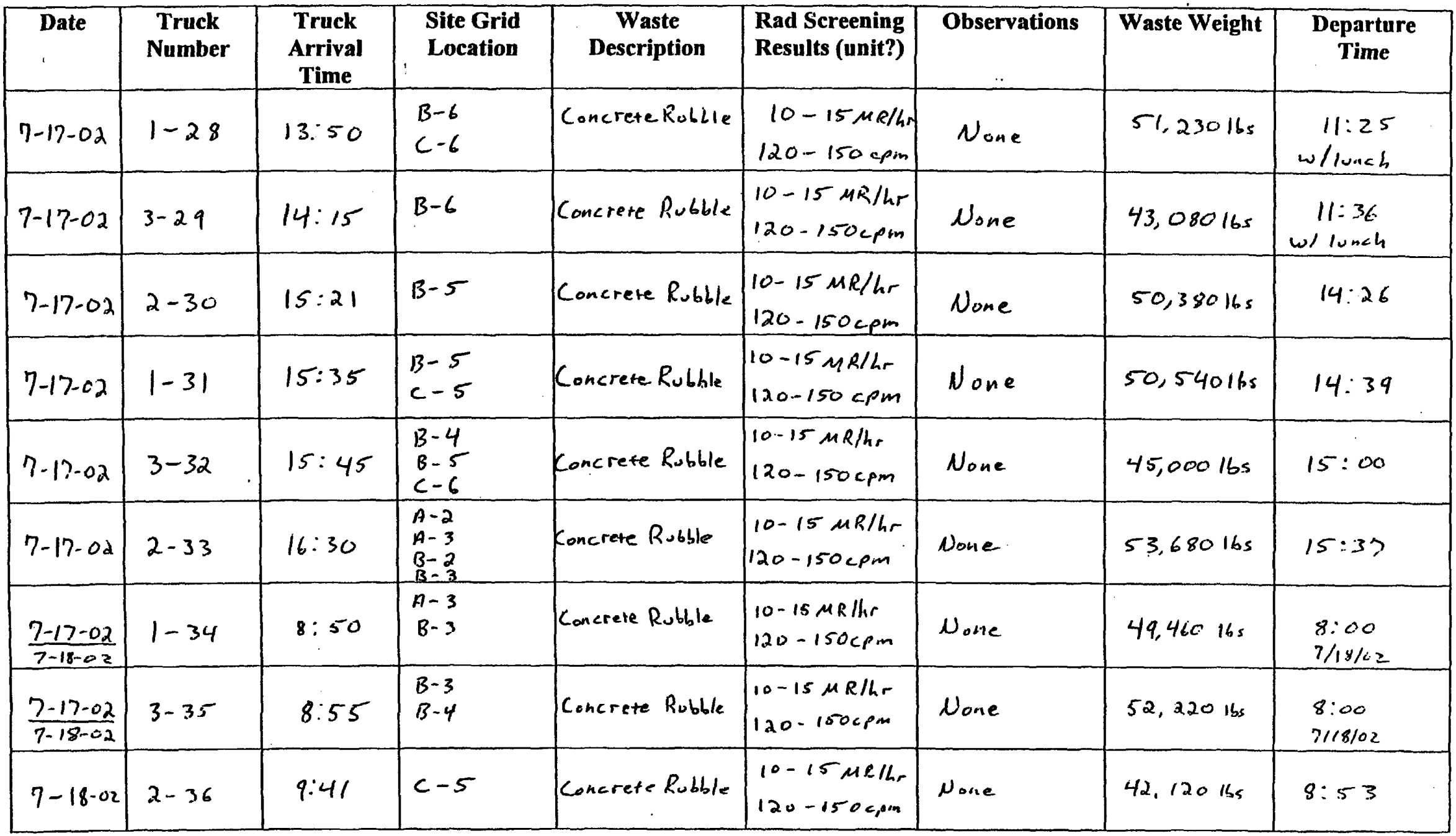

Name: Michael R.Krezic

Date: $7-18-02$

Signature: 


\section{Bechtal Novada}

Environmental Restoration

\section{CAU 425 Waste Tracking Form}

\begin{tabular}{|c|c|c|c|c|c|c|c|c|}
\hline Date & $\begin{array}{c}\text { Truck } \\
\text { Number }\end{array}$ & $\begin{array}{c}\text { Truck } \\
\text { Arrival } \\
\text { Time }\end{array}$ & $\begin{array}{l}\text { Site Grid } \\
\text { Location } \\
\end{array}$ & $\begin{array}{c}\text { Waste } \\
\text { Description }\end{array}$ & $\begin{array}{l}\text { Rad Screening } \\
\text { Results (unit?) }\end{array}$ & Observations & Waste Weight & $\begin{array}{l}\text { Departure } \\
\text { Time }\end{array}$ \\
\hline $7-18-02$ & $1-37$ & $10: 14$ & $\begin{array}{l}B-5 \\
C-5\end{array}$ & Concrete Rubble & $\begin{array}{l}10-15 \mu R / h r \\
120-150 \mathrm{cpm}\end{array}$ & None & $51,7 / 6 \mathrm{lbs}$ & $\begin{array}{l}9: 08 \\
\text { w/gas Fill }\end{array}$ \\
\hline $7-18-02$ & $3-38$ & $10: 17$ & $\begin{array}{l}B-4 \\
C-6\end{array}$ & Concrefe Rubble. & $\begin{array}{l}10-15 \mathrm{MR} / \mathrm{hr} \\
120-150 \mathrm{cpm}\end{array}$ & None & $46,64016 \mathrm{~s}$ & $\begin{array}{l}9: 15 \\
\text { wijas fill }\end{array}$ \\
\hline $7-18-02$ & $2-39$ & $11: 18$ & $c-6$ & Concrete Rubble & $\begin{array}{l}10-15 \mathrm{MR} / \mathrm{hr} \\
120-150 \mathrm{cpm}\end{array}$ & None & $43,34016 \mathrm{~s}$ & $\begin{array}{l}9: 58 \\
\text { wigas fill }\end{array}$ \\
\hline $7-18-02$ & $1-40$ & $11: 22$ & $c-6$ & Concrete Rubble & $\begin{array}{l}10-15 \mu \mathrm{R} / \mathrm{hr} \\
120-150 \mathrm{cmm}\end{array}$ & None & $46,46016 \mathrm{~s}$ & $10: 28$ \\
\hline $7-18-0 x$ & $3-4 i$ & $11: 41$ & $\begin{array}{l}c-5 \\
c-6\end{array}$ & Concrete Rabble & $\begin{array}{l}10-15 \mu \mathrm{k} / \mathrm{hr} \\
120-150 \mathrm{cmm}\end{array}$ & None & 43,360165 & $10: 56$ \\
\hline $7-18-02$ & $2-42$ & $13: 30$ & $c-6$ & Concrete Rubble & $\begin{array}{l}10-15 \mathrm{MR} / \mathrm{hr} \\
120-150 \mathrm{cpin}\end{array}$ & None & 44,820165 & $\begin{array}{l}11: 30 \\
\text { w/lonch }\end{array}$ \\
\hline $7-18-02$ & $1-43$ & $14: 10$ & $\begin{array}{l}c-5 \\
c-6 \\
\end{array}$ & Concrete Rublle & $\begin{array}{l}10-15 \mu \mathrm{R} / \mathrm{hr} \\
120-150 \mathrm{cPm}\end{array}$ & None & $45.180 \mathrm{lbs}$ & $\begin{array}{l}11: 45 \\
\text { w/1unch }\end{array}$ \\
\hline $7-18-02$ & $3-4.4$ & $14: 25$ & $B-4$ & Concrete Rubble & $\begin{array}{l}10-15 \mathrm{MR} / \mathrm{hr} \\
120-150 \mathrm{cpm}\end{array}$ & None & $42,580 \mathrm{lhs}$ & $13: 40$ \\
\hline $7-18-02$ & $2-45$ & $14: 50$ & $B-4$ & Concrete Rubble & $\begin{array}{l}10-15 \mathrm{mR} / \mathrm{hr} \\
120.150 \mathrm{cpom}\end{array}$ & None & $50,580 \mathrm{lhs}$ & $14: 00$ \\
\hline
\end{tabular}

Name:

Date:

$7 / 18 / 02$

Signature: 


\section{Beghtal Nevada}

Environmental Restoration

\section{CAU 425 Waste Tracking Form}

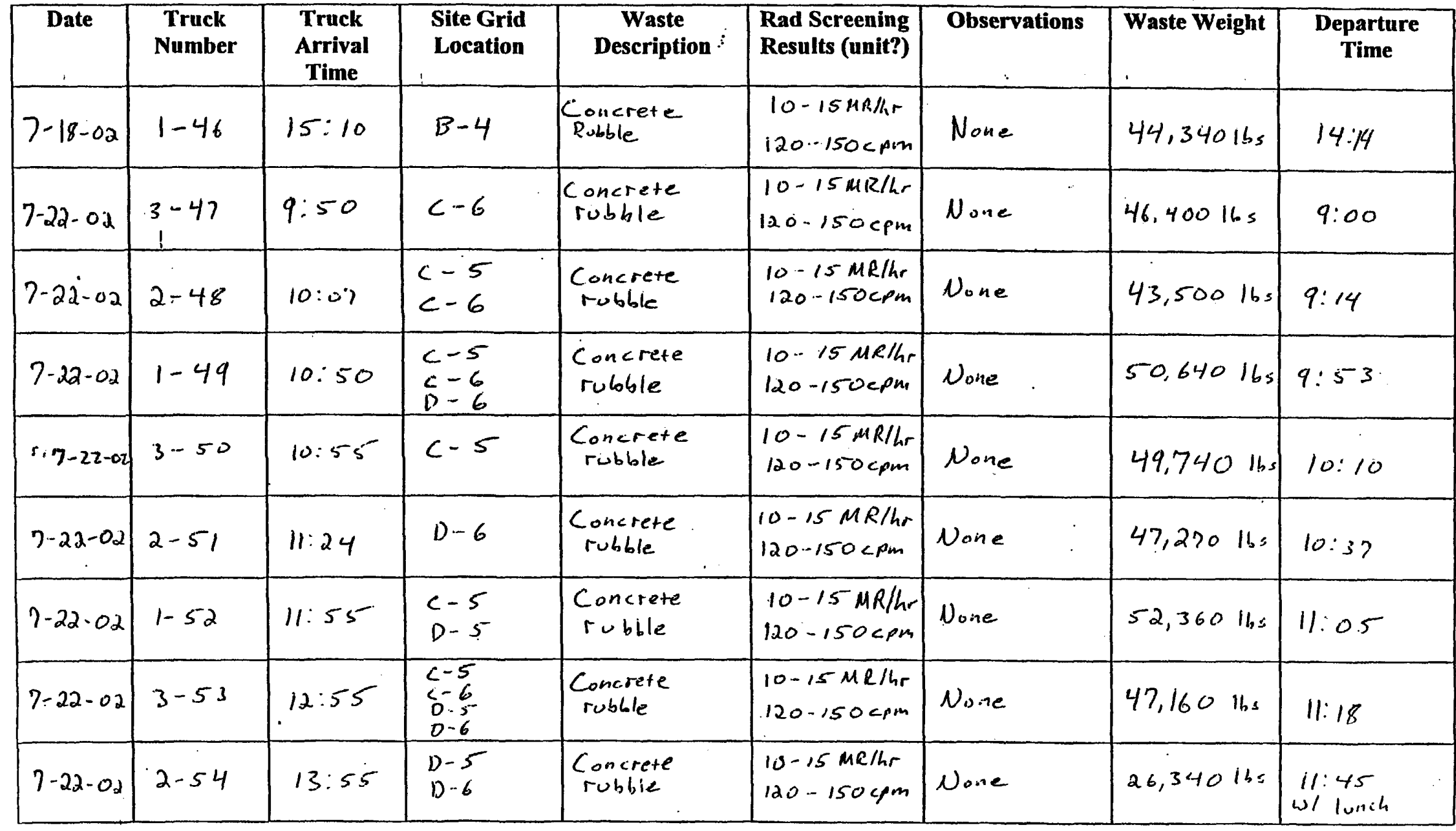

Name: Michael R. K'ruzic Date: $7-22-02$ 


\section{Bechtal Nevada}

\section{Environmental Restoration}

\section{CAU 425 Waste Tracking Form}

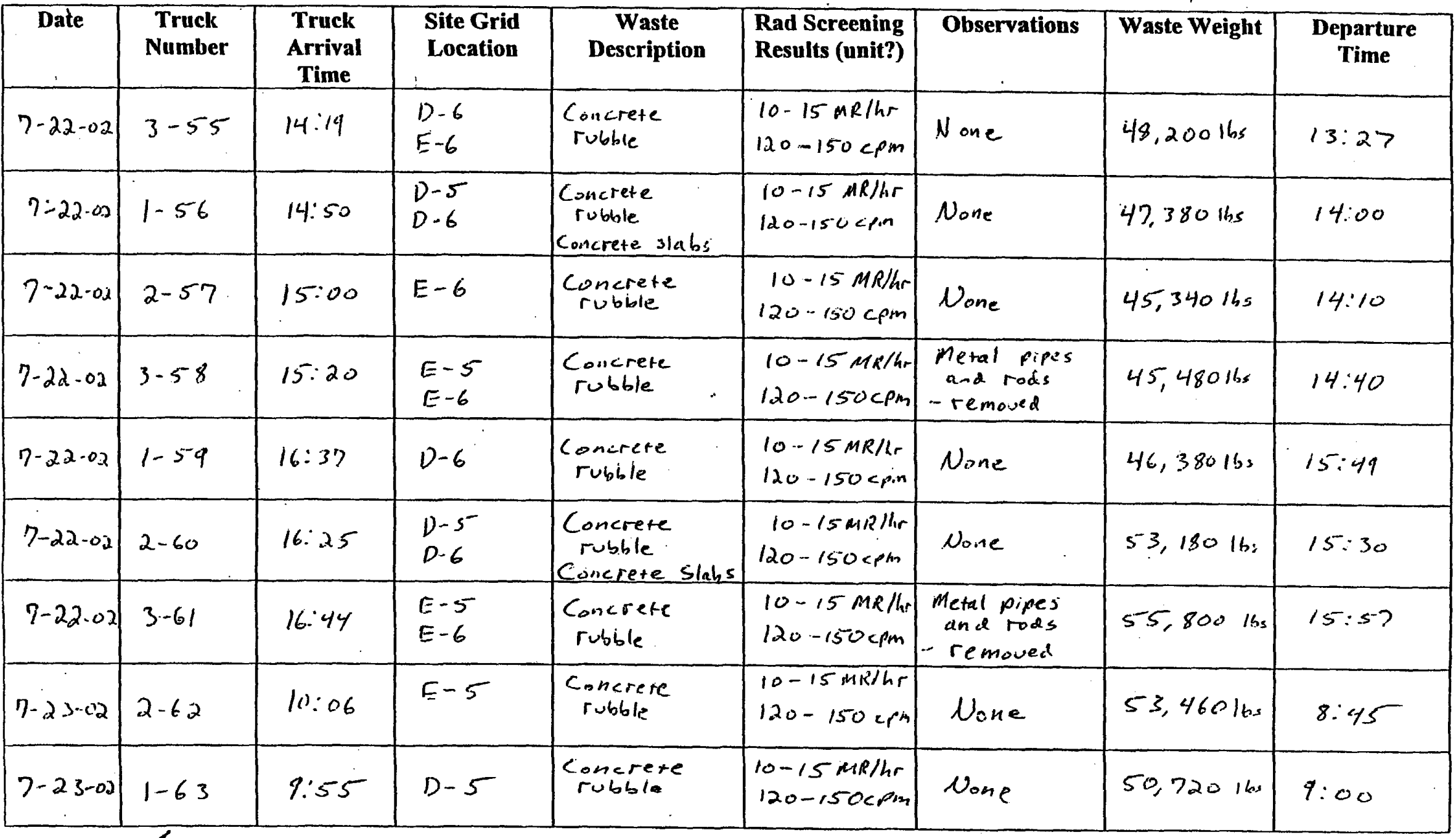

Name:

Date: $2-23-02$

Signature: 


\section{Bechtel Nevada}

Environmental Restoration

CAU 425 Waste Tracking Form

\begin{tabular}{|c|c|c|c|c|c|c|c|c|}
\hline Date & $\begin{array}{l}\text { Truck } \\
\text { Number }\end{array}$ & $\begin{array}{l}\text { Truck } \\
\text { Arrival } \\
\text { Time } \\
\end{array}$ & $\begin{array}{l}\text { Site Grid } \\
\text { Location } \\
\end{array}$ & $\begin{array}{c}\text { Waste } \\
\text { Description }\end{array}$ & $\begin{array}{l}\text { Rad Screening } \\
\text { Results (unit?) }\end{array}$ & $\begin{array}{c}\text { Observations } \\
\end{array}$ & Waste Weight & $\begin{array}{c}\text { Departure } \\
\text { Time }\end{array}$ \\
\hline $7-23-02$ & $3-64$ & $10: 13$ & $D-5$ & $\begin{array}{l}\text { Concrete } \\
\text { rubble }\end{array}$ & $\begin{array}{l}10-15 \mathrm{MR} / \mathrm{hr} \\
120-150 \mathrm{cfm}\end{array}$ & None & 50,360 lbs & $9: 20$ \\
\hline $7-23-02$ & 1.65 & $11: 04$ & $\begin{array}{l}D-5 \\
E-5\end{array}$ & $\begin{array}{c}\text { Concrete } \\
\text { rubble }\end{array}$ & $\begin{array}{l}10-15 \mathrm{MR} / \mathrm{hr} \\
120-150 \mathrm{cfm}\end{array}$ & None & $52,88013.5$ & $10: 14$ \\
\hline $7-.23-02$ & $2-66$ & $11: 07$ & $D-5^{-}$ & $\begin{array}{c}\text { Concrete } \\
\text { rubile }\end{array}$ & $\begin{array}{l}10-15 \mathrm{MR} / \mathrm{hs} \\
120-150 \mathrm{cpm}\end{array}$ & None & 51,640165 & $10: 29$ \\
\hline $7-23-02$ & $3-67$ & $11: 32$ & $\begin{array}{l}D-4 \\
D-5\end{array}$ & $\begin{array}{l}\text { Concrete } \\
\text { rubble }\end{array}$ & $\begin{array}{l}10-15 \mu R / \mathrm{hr} \\
120-150 \mathrm{csm}\end{array}$ & $\begin{array}{l}\text { Metul pipes. } \\
\text { - removed }\end{array}$ & 49,740 ibs & $10: 43$ \\
\hline $7-23.02$ & $1-68$ & $14: 35$ & $\begin{array}{l}D-4 \\
D-5\end{array}$ & $\begin{array}{l}\text { Concrete } \\
\text { rubble }\end{array}$ & $\begin{array}{l}10-15 \mathrm{MR} / \mathrm{hr} \\
120-150 \mathrm{cpm}\end{array}$ & None & $50,400 i 6 x$ & $\begin{array}{c}13: 41 \\
\text { w/ water F:II }\end{array}$ \\
\hline 223.02 & $2-69$ & $13: 44$ & $D=4$ & $\begin{array}{l}\text { Concrete } \\
\text { rubble }\end{array}$ & $\begin{array}{l}10-15-M R G r \\
120-150 \mathrm{cpm}\end{array}$ & None & $36,360 \mathrm{lbs}$ & $\begin{array}{c}11: 39 \\
\text { wl Iuncl }\end{array}$ \\
\hline $7-23-02$ & $3-70$ & $13: 46$ & $\begin{array}{l}D-4 \\
D-5\end{array}$ & $\begin{array}{c}\text { Concrete } \\
\text { rubble }\end{array}$ & $\begin{array}{l}10-15 \mathrm{Me} / \mathrm{hr} \\
120-150 \mathrm{cpm}\end{array}$ & None & 51,140165 & $\begin{array}{c}11: 50 \\
\text { wilunch }\end{array}$ \\
\hline $7-23-02$ & $2-71$ & $14: 19$ & $\begin{array}{l}D-4 \\
D-5 \\
C-4 \\
C=5\end{array}$ & $\begin{array}{l}\text { Concrexe } \\
\text { rubble }\end{array}$ & $\begin{array}{l}10-15 \mathrm{me} / \mathrm{hr} \\
120-150 \mathrm{cpm}\end{array}$ & None & $49,400 \mathrm{lbs}$ & $13: 1-1$ \\
\hline $7-23-2$ & $3-72$ & $15: 05$ & $\begin{array}{c}c-4 \\
c-5\end{array}$ & $\begin{array}{l}\text { Concrete } \\
\text { rubble }\end{array}$ & $\begin{array}{l}10-15 \mathrm{MR} / 4 \mathrm{r} \\
120-150 \mathrm{cmm}\end{array}$ & None & $48,500 / 155$ & $14: 19$ \\
\hline
\end{tabular}

Name: Nirehael Kruziz

Date: $7-23-02$

Signature:

Motanc Lnan 


\section{Béchtel Nevada}

Environmental Restoration

CAU 425 Waste Tracking Form

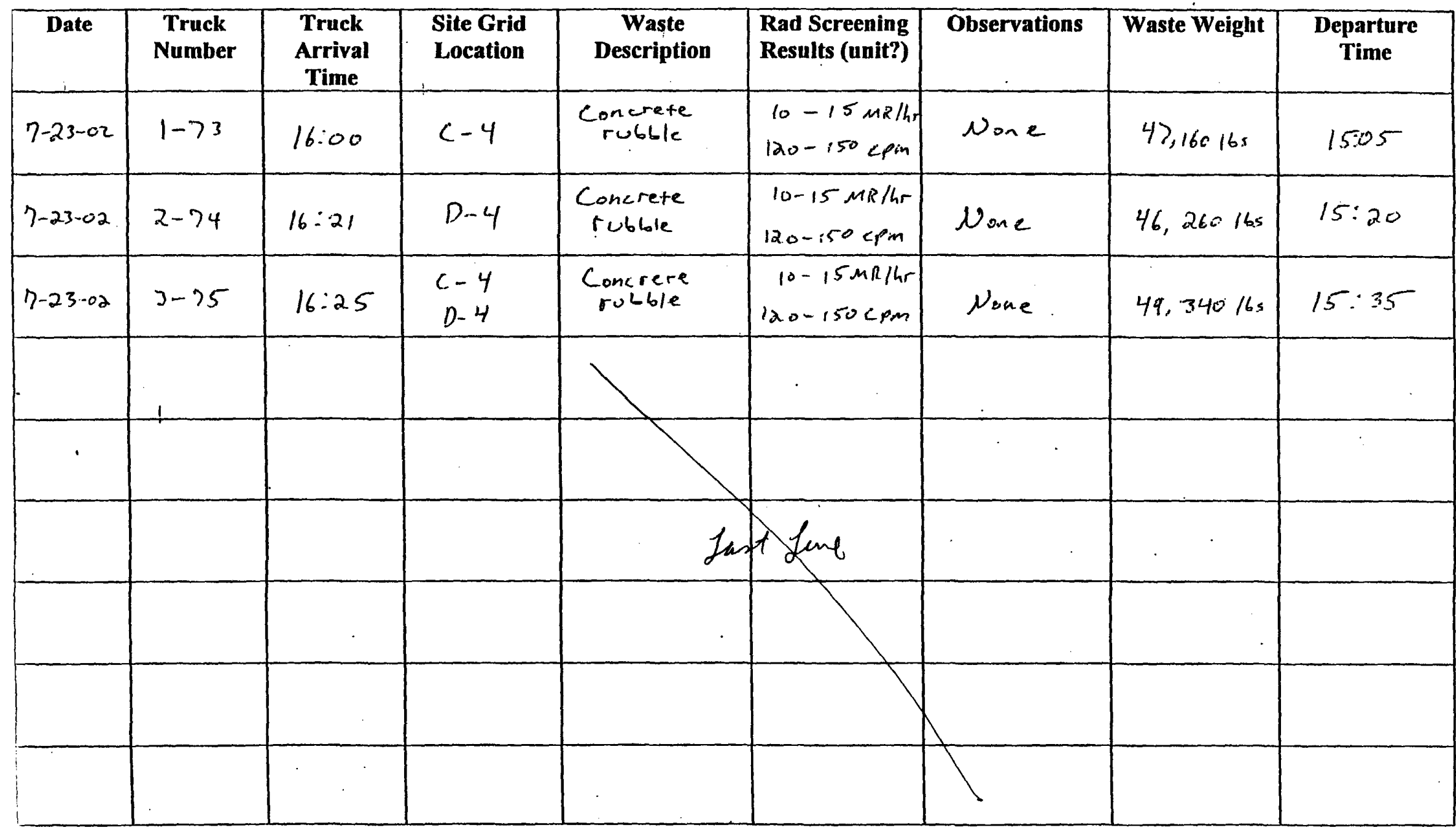

Name:

Date: $7-23-02$

Signature: 


\section{Bechiel Novada}

Environmental Restoration

CAU 425 Waste Tracking Form

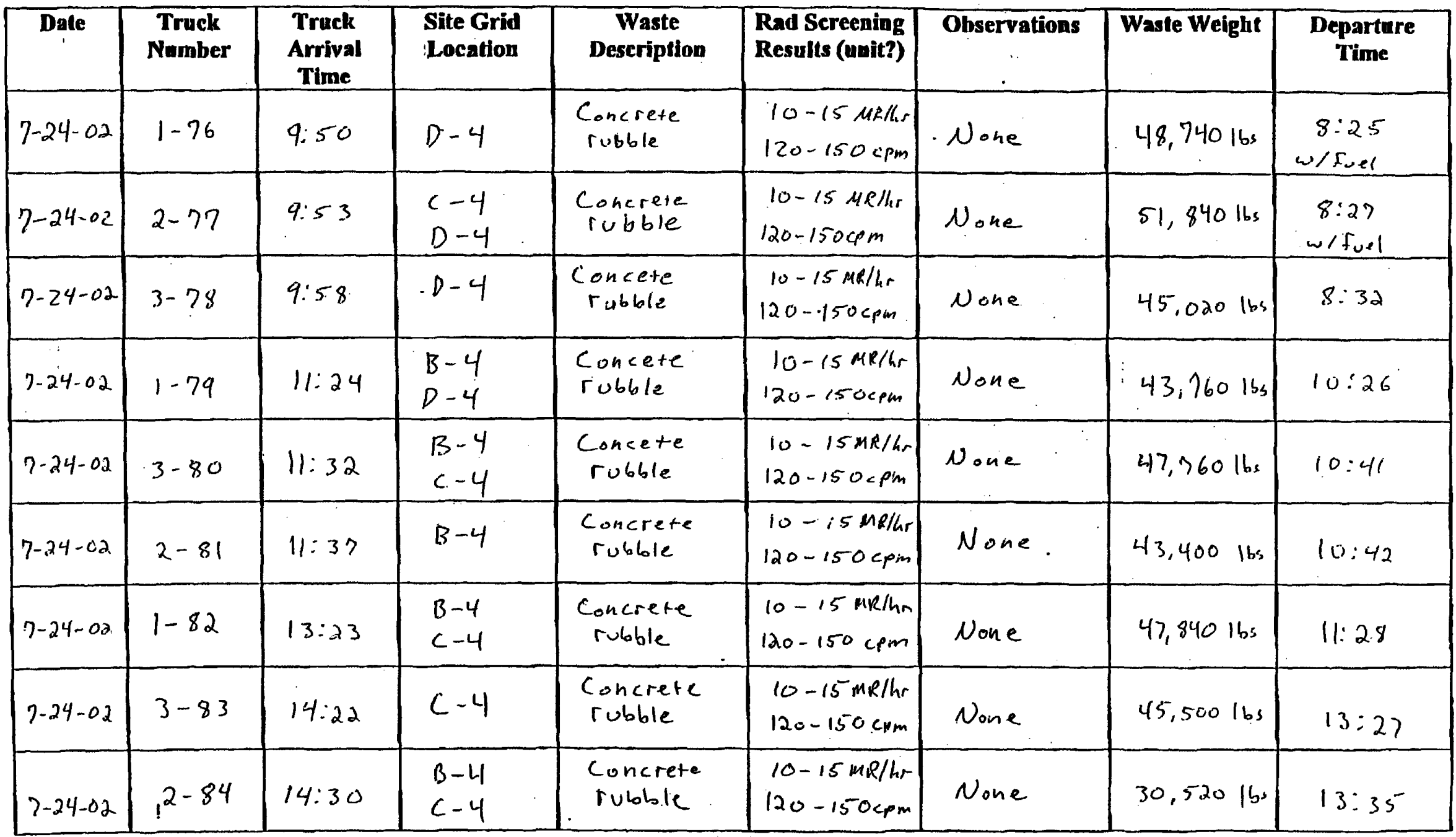

Name: Michael R. Kruzz

Date: $1-24-02$

Nimplur:,$+1 / 2$ 


\section{Bechiel Yovada}

\section{Environmental Restoration}

\section{CAU 425 Waste Tracking Form}

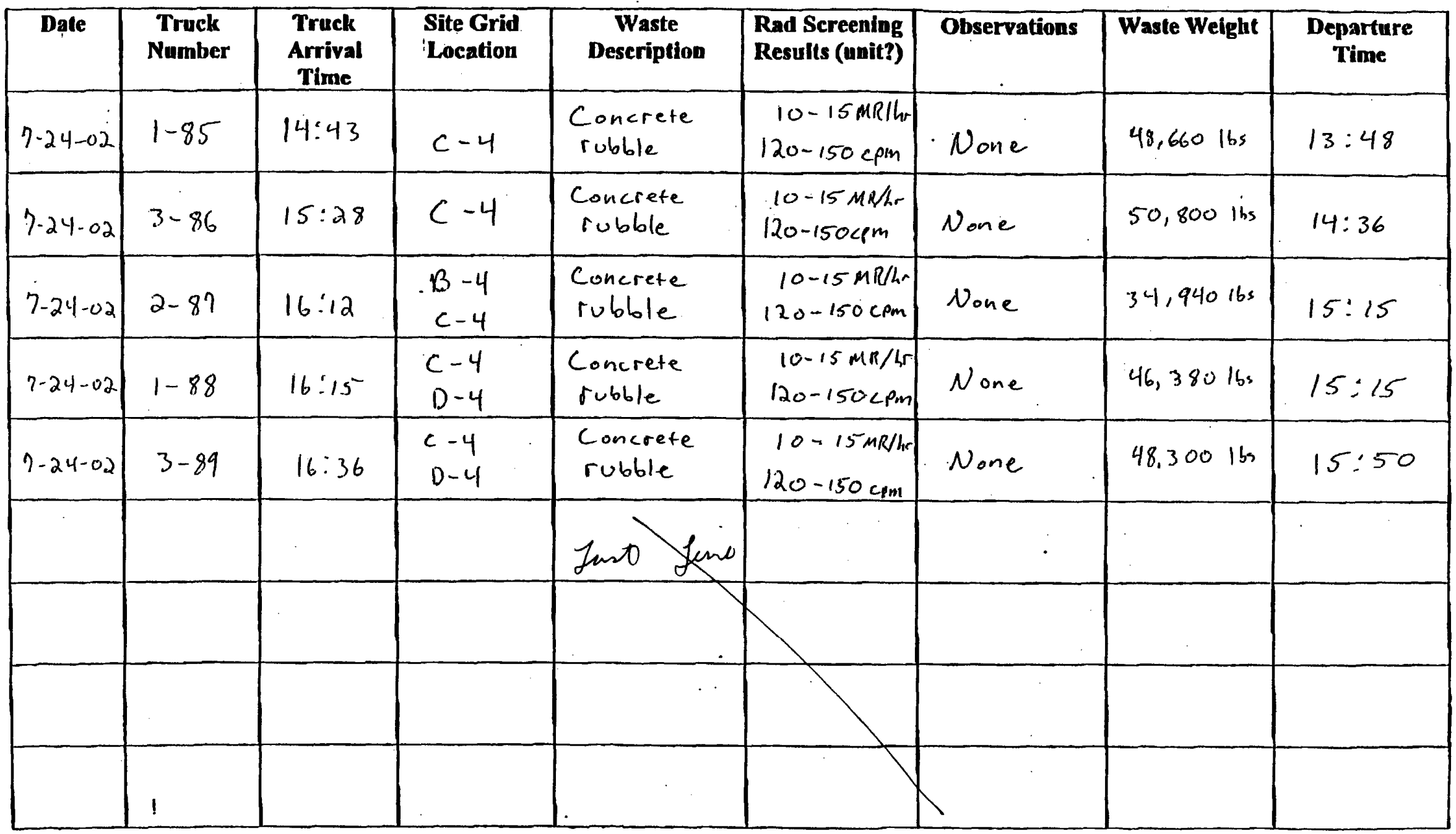

Name:

Michel R. Kaszic

Date: $7-24-00$

Signalure: 


\section{Bechlol youada}

Environmental Restoration

CAU 425 Waste Tracking Form

\begin{tabular}{|c|c|c|c|c|c|c|c|c|}
\hline Date & $\begin{array}{l}\text { Truck } \\
\text { Namber }\end{array}$ & $\begin{array}{c}\text { Truck } \\
\text { Arrival } \\
\text { Time } \\
\end{array}$ & $\begin{array}{l}\text { Site Grid } \\
\text { Location }\end{array}$ & $\begin{array}{c}\text { Waste } \\
\text { Description }\end{array}$ & $\begin{array}{l}\text { Rad Screening } \\
\text { Results (unit?) }\end{array}$ & Observations & Waste Weight & $\begin{array}{l}\text { Departure } \\
\text { Time }\end{array}$ \\
\hline $7-25-02$ & $3-90$ & $9: 22$ & $D-4$ & $\begin{array}{l}\text { Concrete } \\
\text { rubble }\end{array}$ & $\begin{array}{l}10-15 \mathrm{MR} / \mathrm{hr} \\
120-150 \mathrm{cpm}\end{array}$ & None & 48,320165 & $8: 30$ \\
\hline $7-25-02$ & $2-91$ & $9: 51$ & $\begin{array}{l}C-4 \\
D-4\end{array}$ & $\begin{array}{l}\text { Concrete } \\
\text { rublole } \\
\text { Concrete slabs }\end{array}$ & $\begin{array}{l}10-15 \mathrm{MR} / \mathrm{hr} \\
120-150 \mathrm{cpm}\end{array}$ & None & $48.480 \mathrm{lbs}$ & $8: 53$ \\
\hline $7-25-02$ & $3-93$ & $10: 34$ & $c-3$ & $\begin{array}{l}\text { Concrete } \\
\text { rubble }\end{array}$ & $\begin{array}{l}10-15 \mathrm{MR} / \mathrm{hr} \\
120-150 \mathrm{cpm}\end{array}$ & None & 47,060160 & $9: 35$ \\
\hline $2-25-02$ & $2-94$ & $11: 10$ & $\begin{array}{l}c-3 \\
c-4\end{array}$ & $\begin{array}{l}\text { Concrete } \\
\text { rubble } \\
\text { Soil }\end{array}$ & $\begin{array}{l}10-15 \mathrm{mg} / \mathrm{hr} \\
120-150 \mathrm{cmm}\end{array}$ & None & $51,60016 \mathrm{~s}$ & $10: 15$ \\
\hline $7-25-02$ & $3-96$ & $13: 00$ & $c-3$ & $\begin{array}{l}\text { Concrete } \\
\text { rubble } \\
\text { Soil }\end{array}$ & $\begin{array}{l}10-15 \mathrm{mR} / \mathrm{hr} \\
120-150 \mathrm{cpm}\end{array}$ & None & $45.740 / 6 s$ & $\begin{array}{r}11: 01 \\
w / 1 \text { unci } \\
\end{array}$ \\
\hline $7-25-02$ & $2-97$ & $13: 15$ & $\begin{array}{l}B-3 \\
B-4\end{array}$ & $\begin{array}{l}\text { Concrere } \\
\text { rubble }\end{array}$ & $\begin{array}{l}10-15 \mathrm{MR} / \mathrm{hr} \\
120-150 \mathrm{cpm}\end{array}$ & None & $45,29016 \mathrm{~s}$ & $\begin{aligned} & 11: 22 \\
& \text { wi } 1 \text { unch } \\
&\end{aligned}$ \\
\hline $7-25-02$ & $1^{1-98}$ & $13: 30$ & $\begin{array}{l}B-3 \\
C-3 \\
D-3\end{array}$ & $\begin{array}{l}\text { Coucrete } \\
\text { rubble. }\end{array}$ & $\begin{array}{l}10-15 \mathrm{MR} / \mathrm{hr} \\
120-150 \mathrm{cem}\end{array}$ & None & $50,440 \mathrm{lss}$ & $\begin{array}{l}11: 45 \\
\text { w/lunch }\end{array}$ \\
\hline
\end{tabular}

Name: Michael R. Kruzic

Date: $7-25-01$ 


\section{Bechter Movada}

Environmental Restoration

CAU 425 Waste Tracking Form

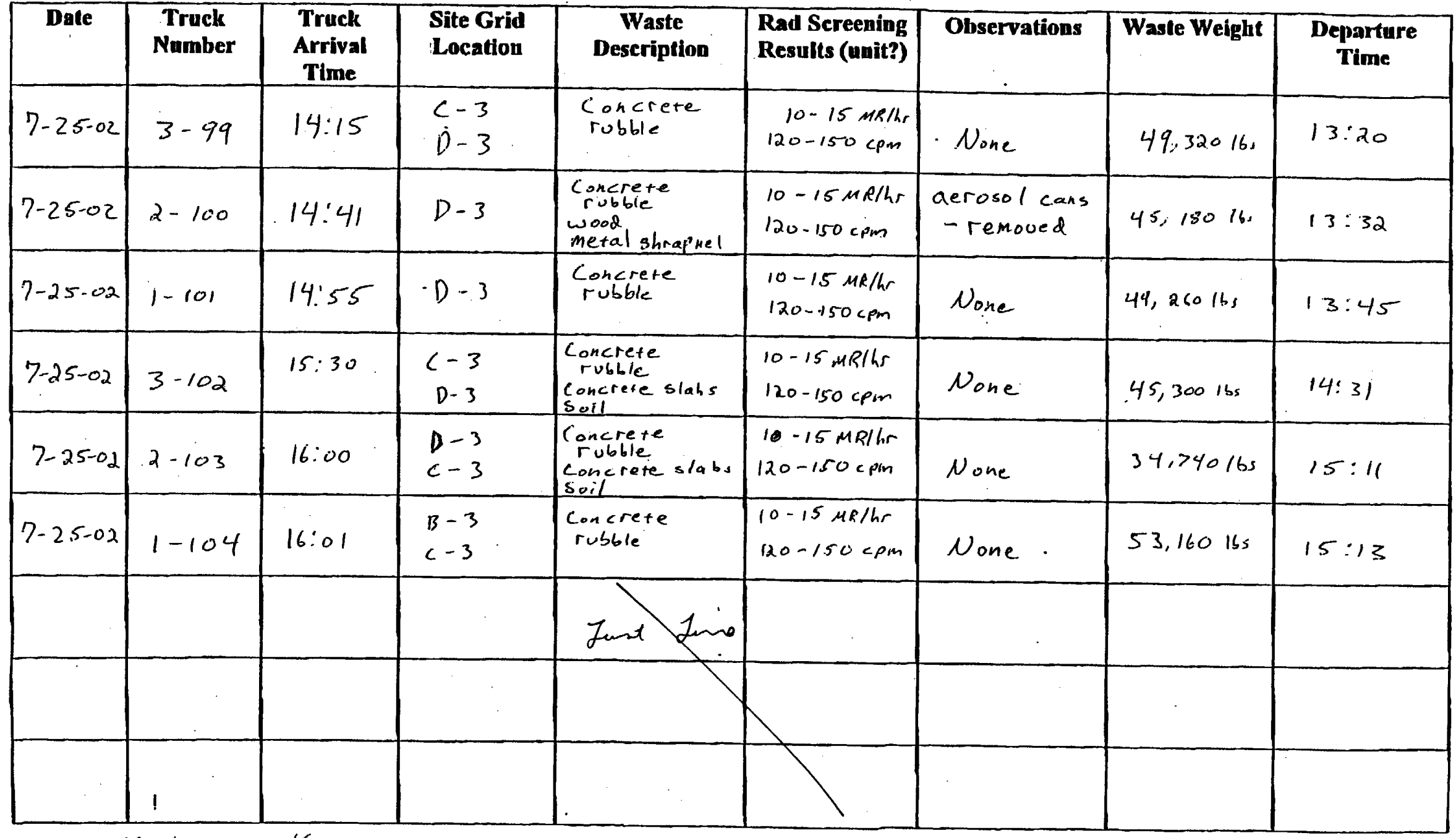

Namè Prichael R. Krazic

Date: $7-25-0.2$

Signalure: 


\section{Bechter yerada}

\section{Cnvironmental Restoration}

CAU 425 Waste Tracking Form

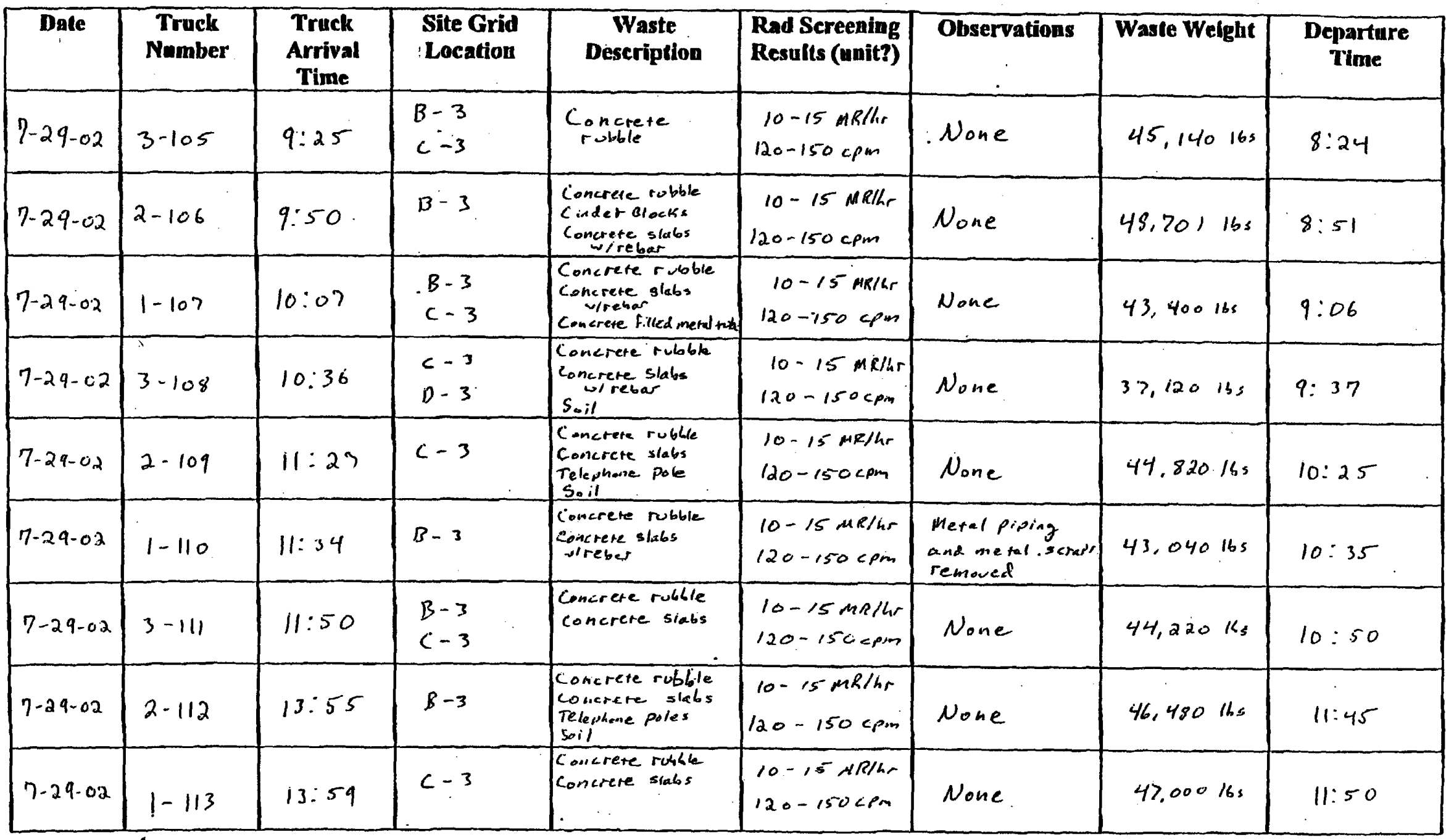

Name: Michael R. Kruz:c

Date: 7-29-02 


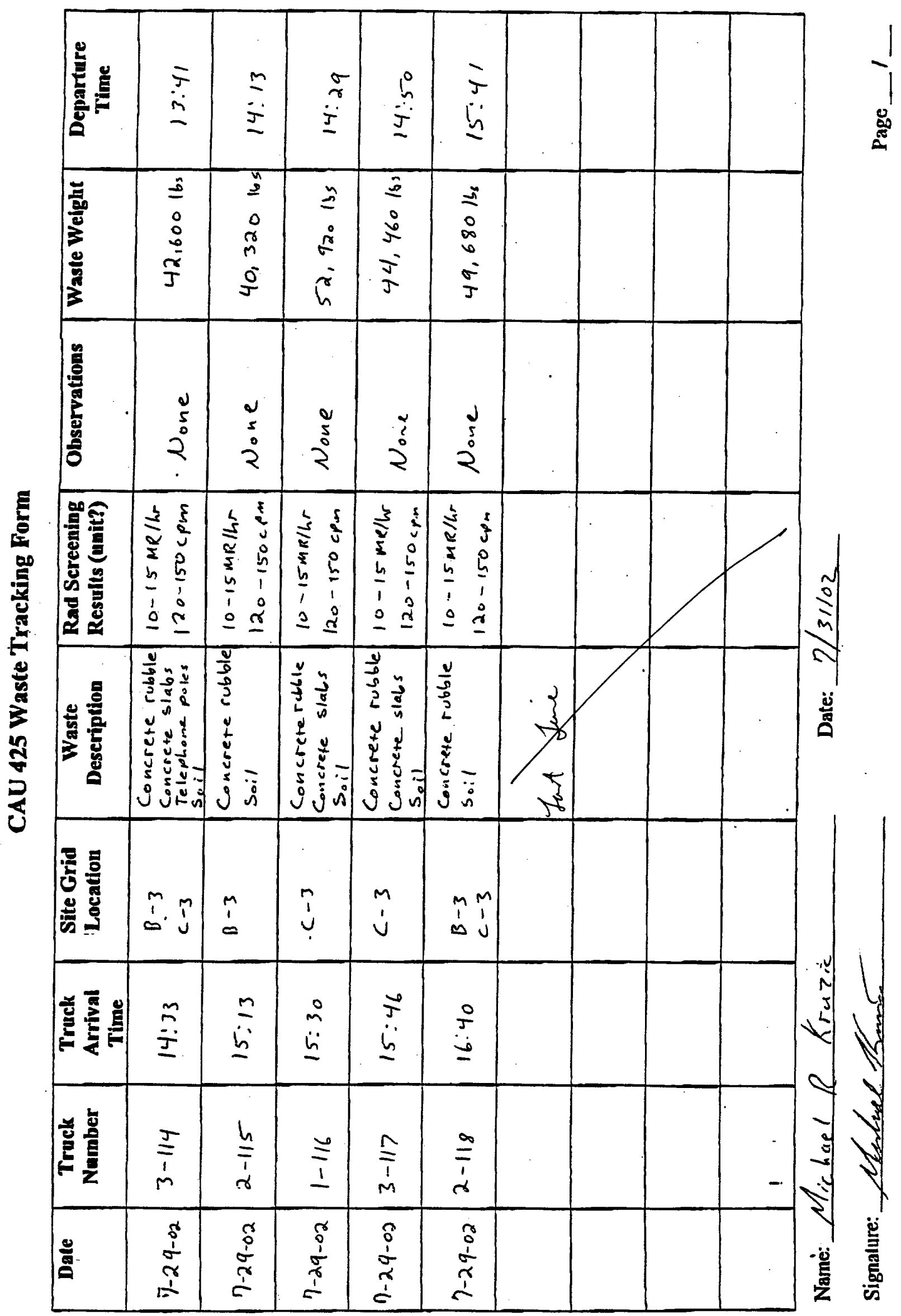




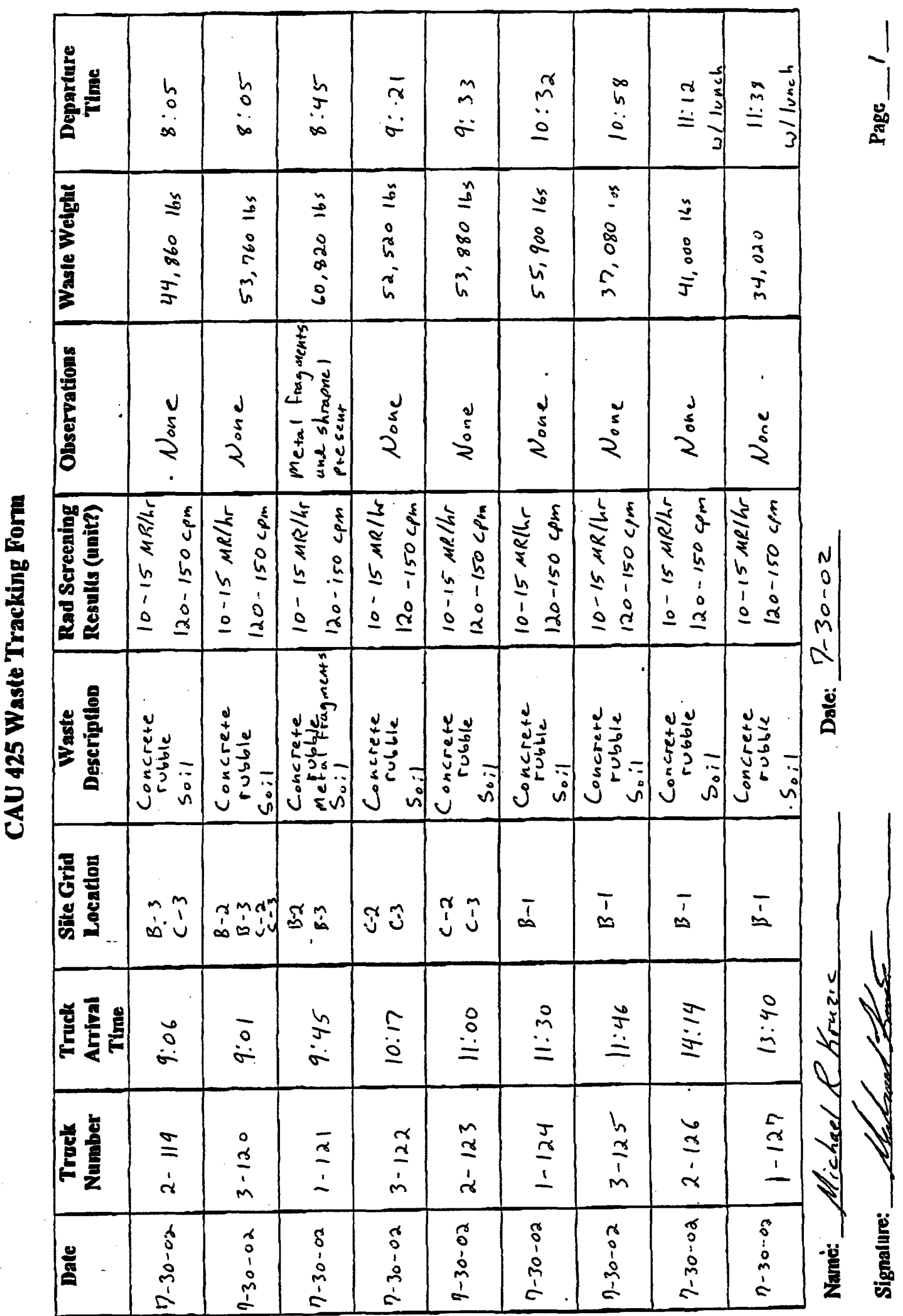




\section{Bechter fougda}

Cuviroumental Restoration

CAU 425 Waste Tracking Form

\begin{tabular}{|c|c|c|c|c|c|c|c|c|}
\hline Date & $\begin{array}{l}\text { Truek } \\
\text { Number }\end{array}$ & $\begin{array}{c}\text { Truelk } \\
\text { Arrival } \\
\text { Time } \\
\end{array}$ & $\begin{array}{l}\text { Site Grid } \\
\text { Location }\end{array}$ & $\begin{array}{c}\text { Waste } \\
\text { Deseriptlon }\end{array}$ & $\begin{array}{l}\text { Rad Screening } \\
\text { Resul(s (unit?) }\end{array}$ & Observations & Waste Welght & $\begin{array}{l}\text { Departure } \\
\text { Time }\end{array}$ \\
\hline $7-30-02$ & $3-126$ & $14: 01$ & $B-1$ & Soil & $\begin{array}{l}10-15 \mathrm{MR} / \mathrm{hr} \\
120.150 \mathrm{cpm}\end{array}$ & None & $37,880 \mathrm{ks}$ & $\begin{array}{c}11: 57 \\
\text { w/ lunch } \\
\end{array}$ \\
\hline $7-30-02$ & $1-127$ & $16: 33$ & $B-1$ & Soil & $\begin{array}{l}10-15 \mathrm{MR} / \mathrm{hr} \\
120-150 \mathrm{cpm}\end{array}$ & None & $51,720 \mathrm{lbs}$ & $\begin{array}{c}15: 40 \\
\text { w/ water fill }\end{array}$ \\
\hline $7-30-02$ & $3-128$ & $15: 11$ & $-B-1$ & $S_{0}: 1$ & $\begin{array}{c}10-15 \mathrm{MR} / \mathrm{hr} \\
120 \div 150 \mathrm{cpm}\end{array}$ & None & $50,200 \mathrm{lbs}$ & $14: 27$ \\
\hline $7-30-02$ & $2-129$ & $15: 49$ & $B-1$ & $\begin{array}{l}\text { Concrete slabs } \\
\text { Concrete rubble } \\
\text { soil }\end{array}$ & $\begin{array}{l}10-15 \mathrm{mR} / \mathrm{hr} \\
120-150 \mathrm{cpm}\end{array}$ & None & $47,500 \mathrm{lbs}$ & $14: 45$ \\
\hline $7-30-02$ & $3-130$ & $16: 27$ & $c-2$ & $\begin{array}{l}\text { Concrete rubble } \\
\text { Soil }\end{array}$ & $\begin{array}{l}10-15 \mathrm{mR} / \mathrm{hr} \\
120-150 \mathrm{~cm}\end{array}$ & None & $55,800 \mathrm{lbs}$ & $15: 38$ \\
\hline $7-31-02$ & $2-131$ & $9 \cdot 33$ & $<-2$ & So:il & $\begin{array}{l}10-15 \mathrm{MR} / \mathrm{hr} \\
120-150 \mathrm{cpm}\end{array}$ & None & $24,14016 s$ & $8: 25$ \\
\hline $7-31-02$ & $3-132$ & $16: 28$ & $\begin{array}{l}c-1 \\
c-2\end{array}$ & So:1 & $\begin{array}{l}10-15 \mathrm{~m} / \mathrm{hr} \\
120-150 \mathrm{cpm}\end{array}$ & None & 46,820165 & $15: 45$ \\
\hline & & & & & & & & \\
\hline & $!$ & & & & & - & & \\
\hline
\end{tabular}

Name: Michosel R. Kruzic

Dale: $2-30-02$

Signalure: 


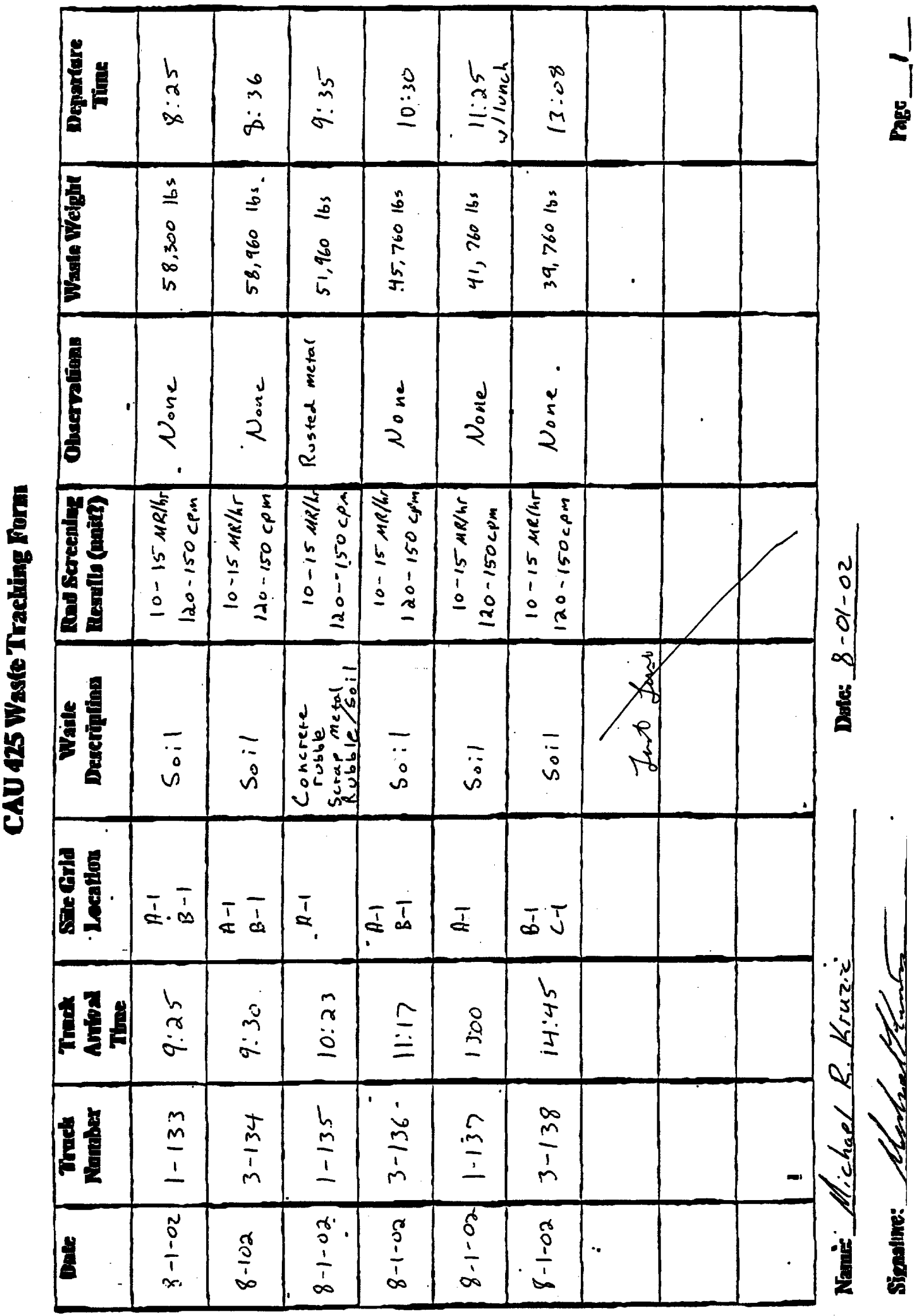




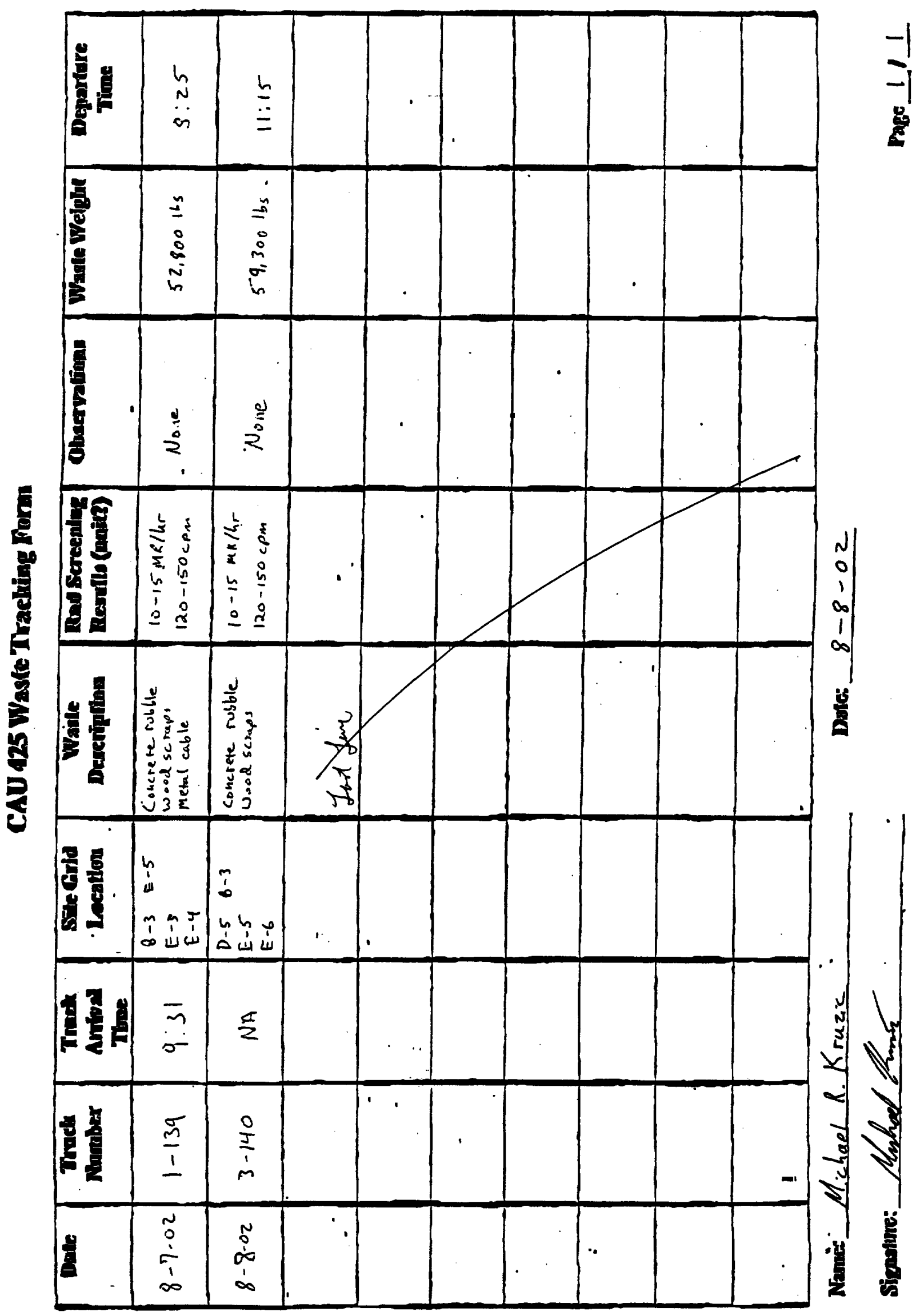


CLOSURE REPORT - CAU 425

Section: Appendix B

Revision: 0

Date: February 2003

THIS PAGE INTENTIONALLY LEFT BLANK 
CLOSURE REPORT - CAU 425

Section: Appendix C

Revision: 0

Date: February 2003

\section{APPENDIX C}

\section{RADIOLOGICAL SURVEY FORMS}


CLOSURE REPORT - CAU 425

Section: Appendix C

Revision: 0

Date: February 2003

THIS PAGE INTENTIONALLY LEFT BLANK 


\section{Bechtel Nevada}

RADIATION SURVEY REPORT

Number $0 x-16$ - ifk of Page 1 of 1

RCT(S): R. PARKE

HEALTH PHYSICIST: Me Bride

Dous MC Sride
COUNTING EQUIPMENT USED
IN COLUMN

IN COLUMN $\quad 1 \% 2$

\begin{tabular}{ll} 
NUMBER \\
$L 2929$ & 155562 \\
\hline
\end{tabular} IN COLUMN

ALPHA EFFICIENCY

\begin{tabular}{|c|c|}
\hline EFFICIENCY & EFFICIENCY \\
\hline MDA &.$\%$ \\
\hline & M. \\
\hline
\end{tabular}

ALPHA NUMBER

EFF

MDA A $^{\text {MDA }}$

MDA

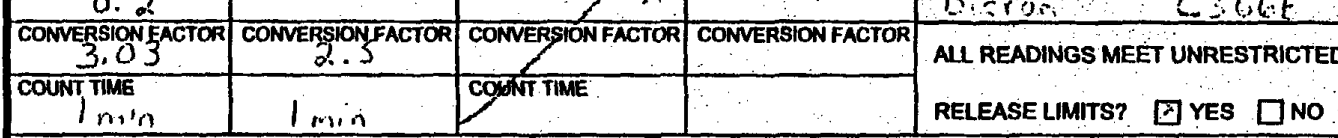

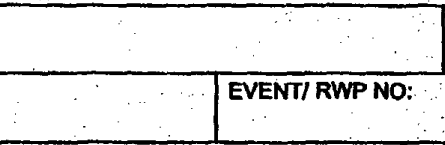
SIGNATURE: $y$.

DATE:

PURPOSE:

Debri: Remunat TTR Dame Fram CAU425

INSTRUMENT NUMBER

Model ia NUMBER 4655

COUNTING EQUIPMENT USED

IN COLUMN

INSTRUMENT

4

4

NUMBER

INSTRUMENT USED

INSTRUMENT
IN COLUMN

INSTRUMENT USED

IN COLUMN

COUNTING EQUIPUENT

IN COLUMN

INSTRUTENT

MENT USED

colom

NUMBER

COLUMN 1 COLUMN2

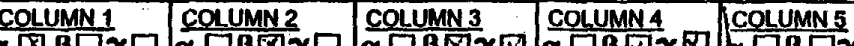

OTHER

YORK OROER:

$1-11 \cdot 2 a$

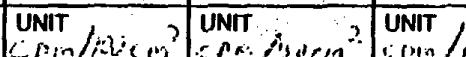

Gindicm

FIXED+

TIME $\quad$ DESCRIPTION OF SURVEY

FIXED +

20

REMOVER
SWIPE
NAA

0745 BACKGROUND (Gross)

150 Truck lora d H 1 direst Recolings

SWPE SWPE

C.11 4.25 IN COLUMN

INSTRUMENT USED

IN COLUMN $N$

INSTRUMENTUSED

N COLUMD

NSTROMENT

NUMBER

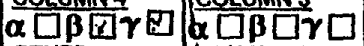
OTHER

UNIT $/ 6$, UNIT

X) 1

FIXED + FIXED +

REMOVE $⿴ 囗$ REMOVE

SWIPE $\square$ SWPE

$T$ Tiuck lonit 2 direct Rending

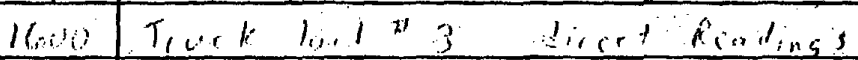

1630 Fnd a doy font $L$ ader

$16 \%$ Find of day 2uyd Dimp Tiucle

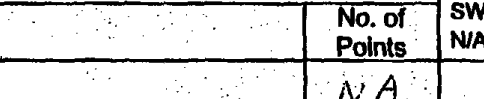

\begin{tabular}{l|l|l|l} 
& N/A & N/A \\
\hline 0 & 71 &
\end{tabular}

NA D

NAPE

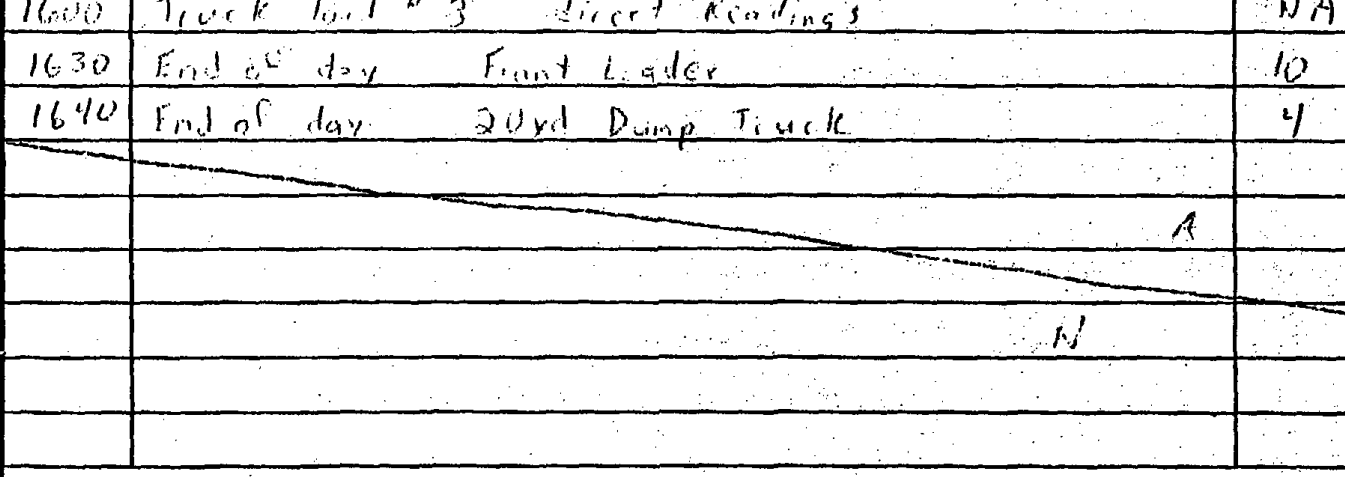

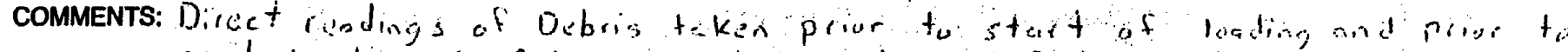

eacl truek load. All smears taken at cojof day after equiponent is finished fortlie day.

FOLLOW UP REQUIRED? YES $\square$ NO $\square$

ALL READINGS ARE NET ABOVE BACKGROUND UNLESS NOTED 


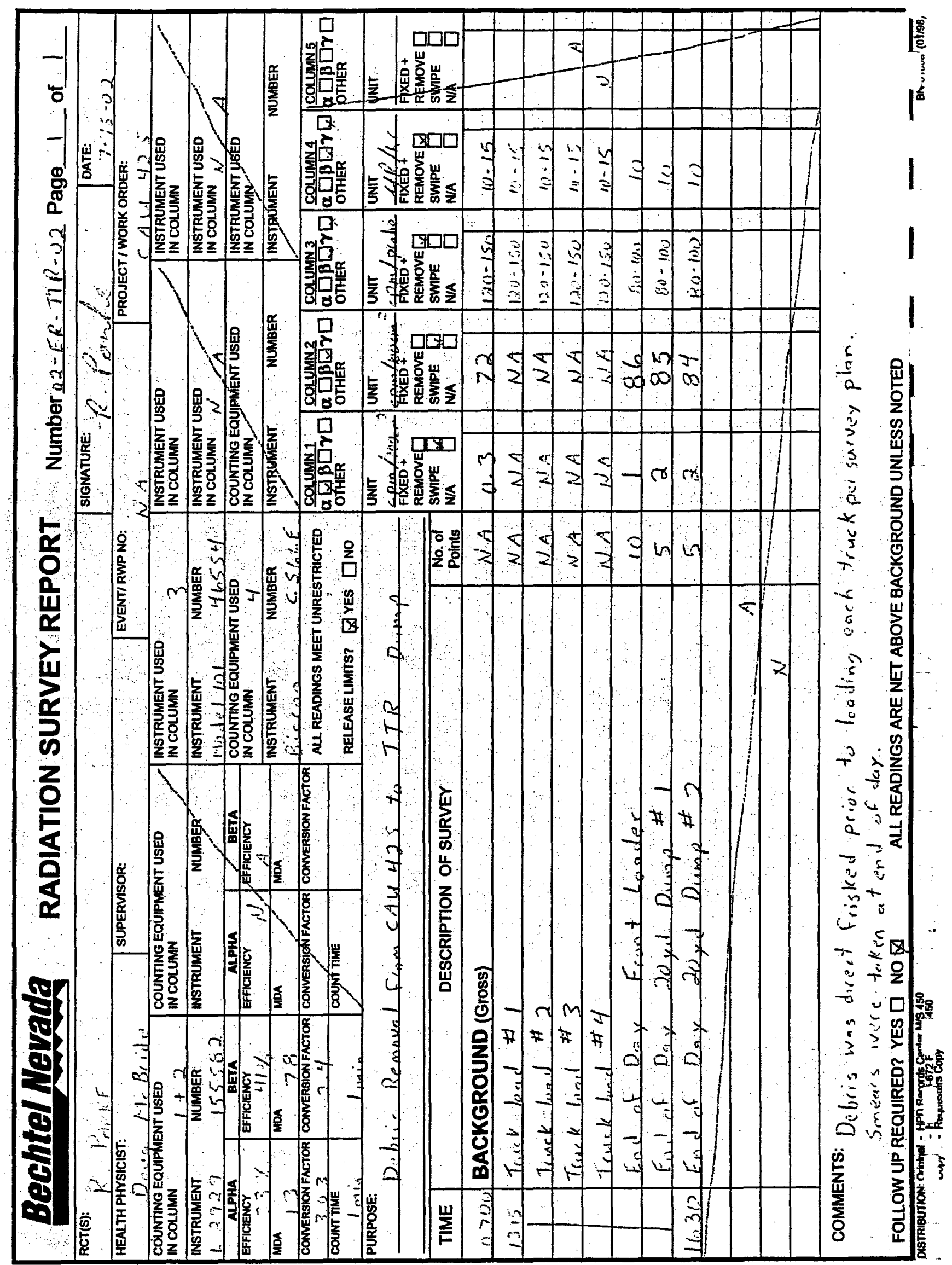




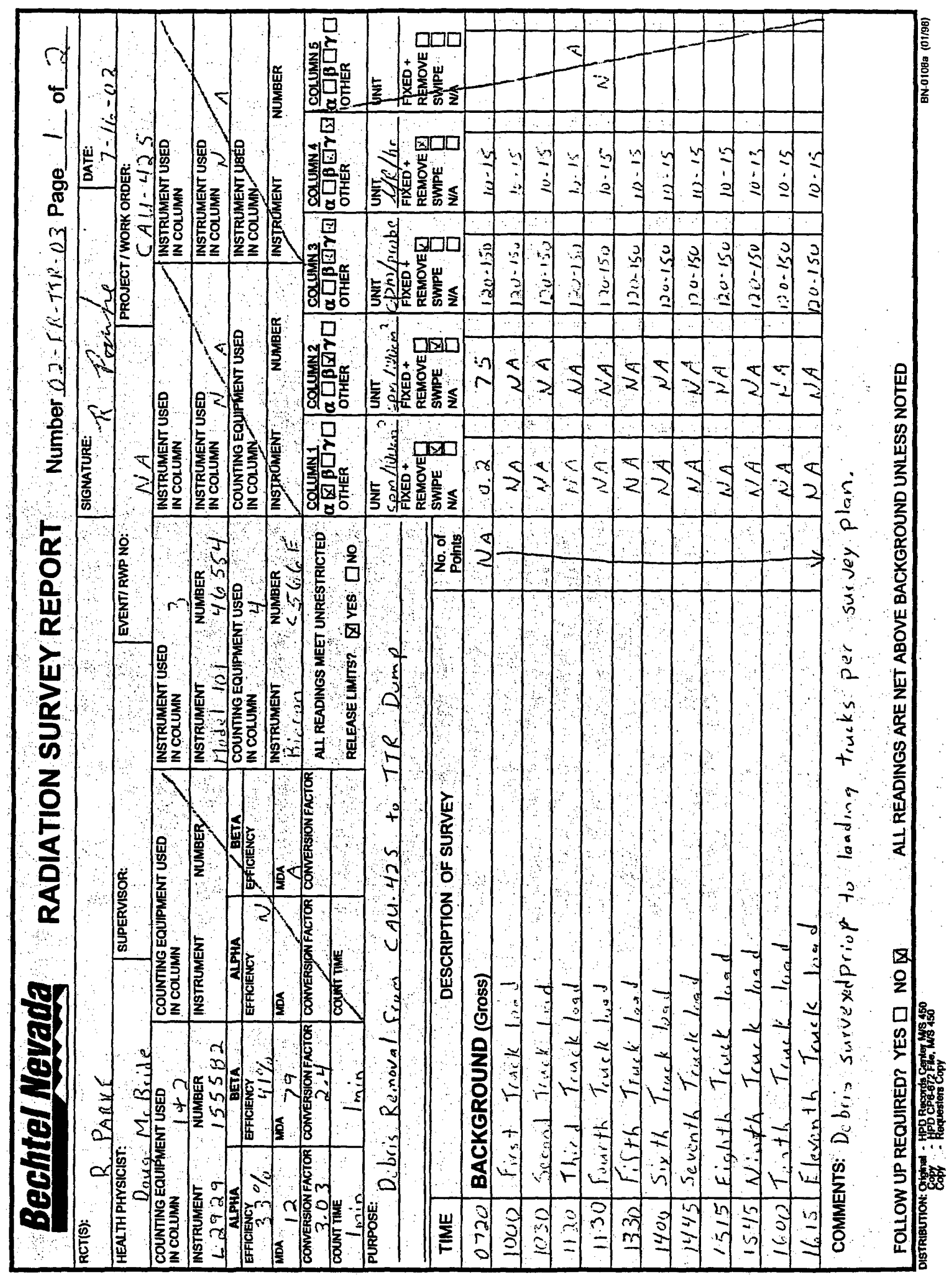




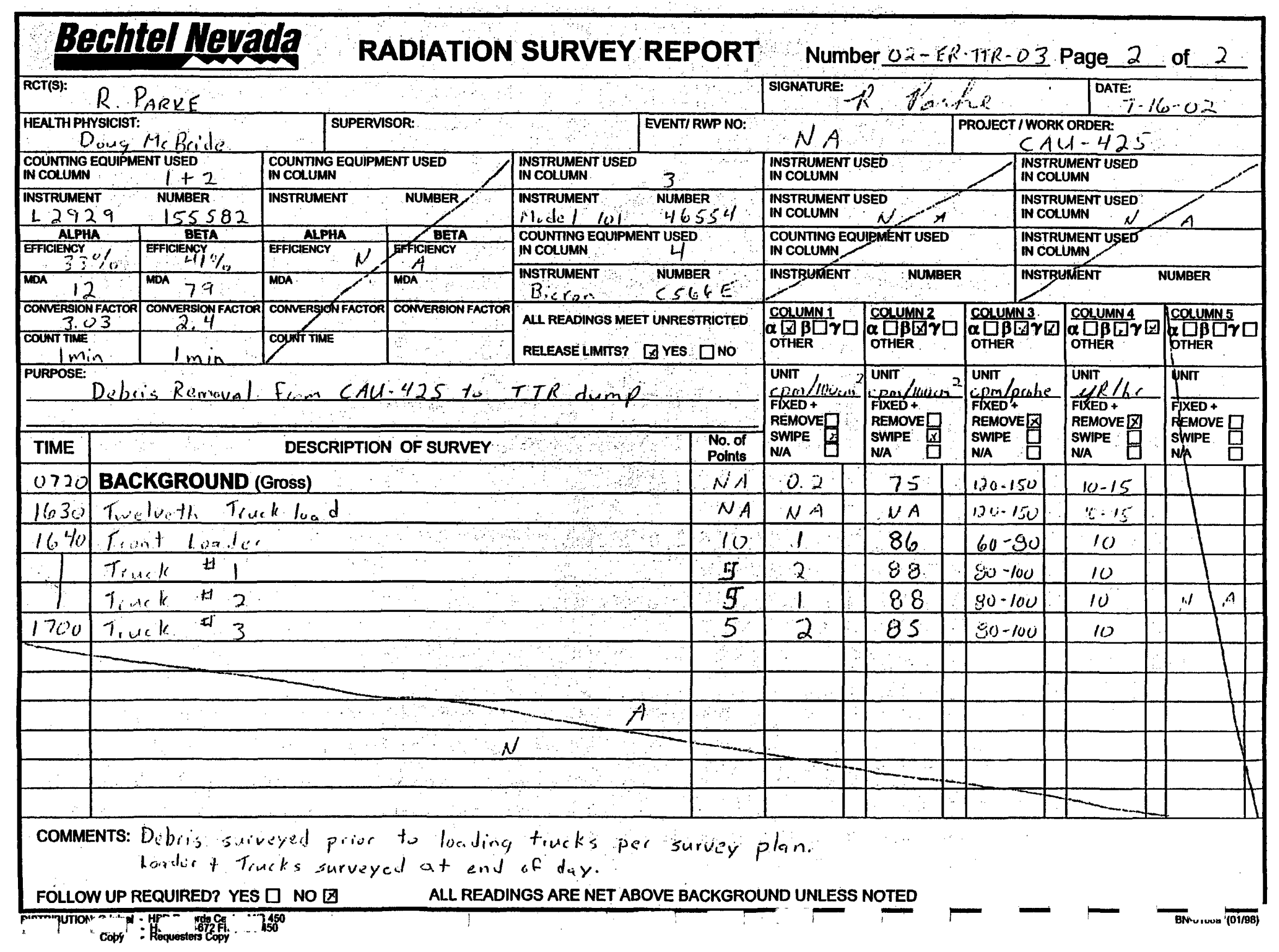




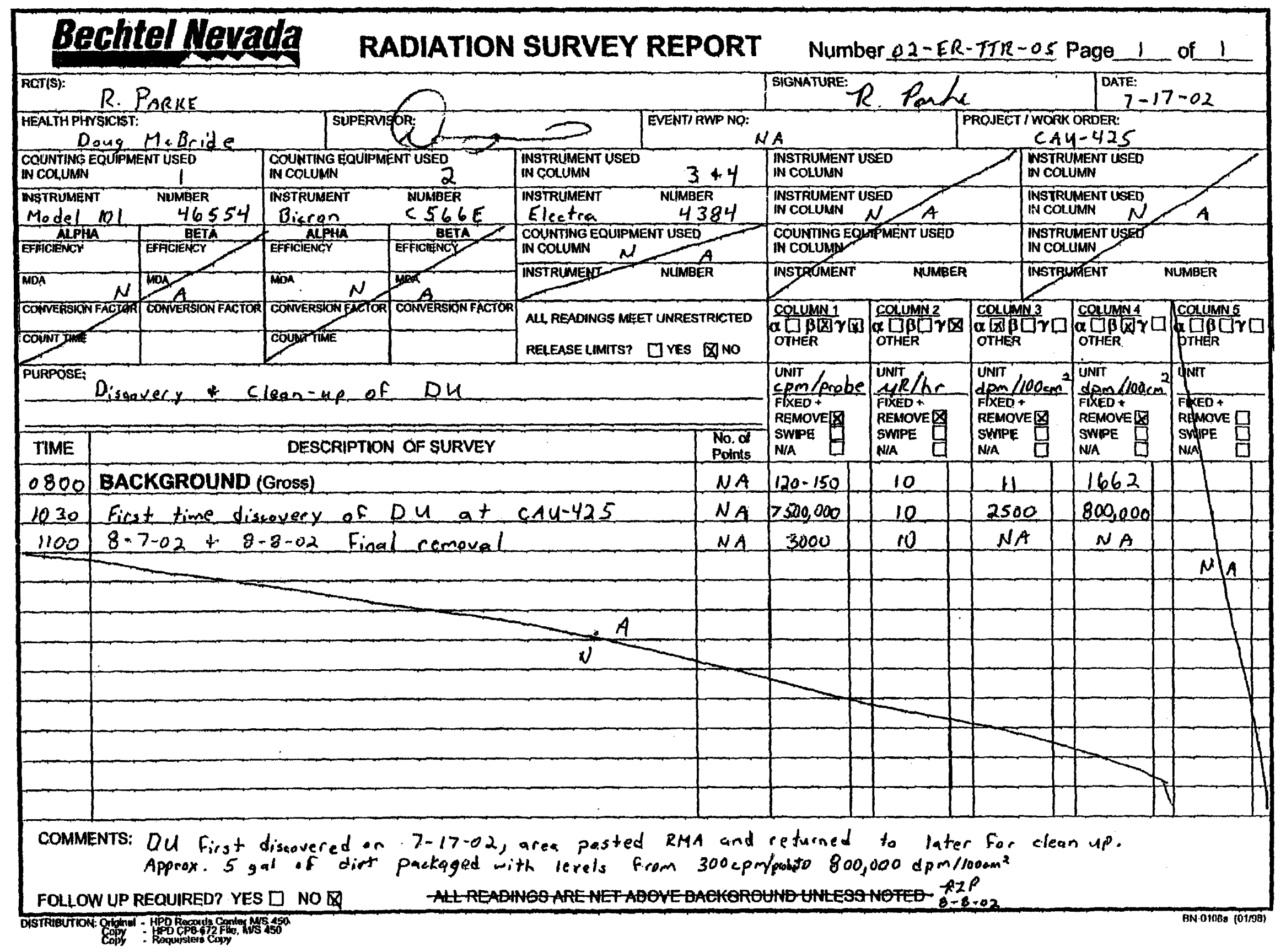




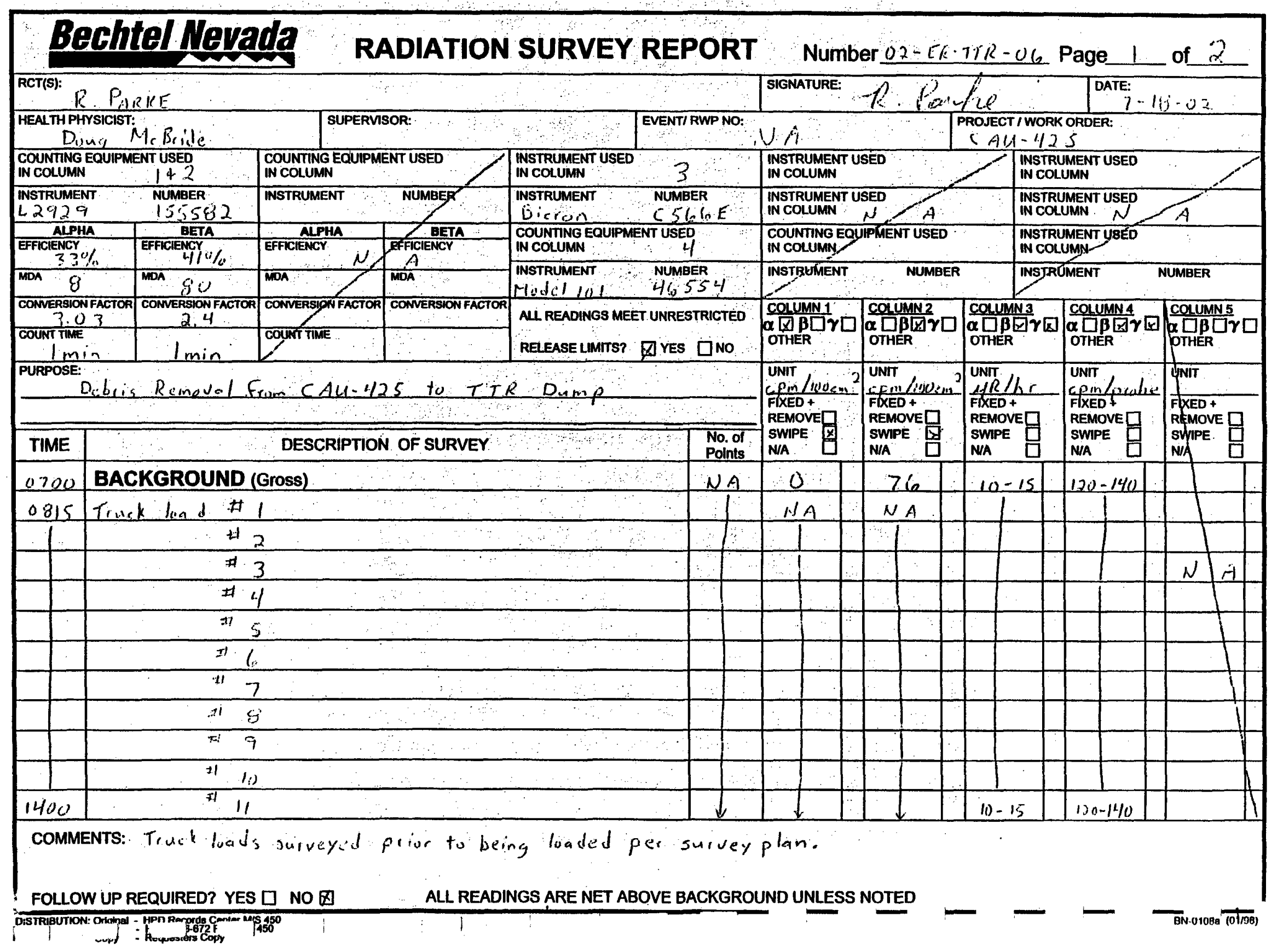




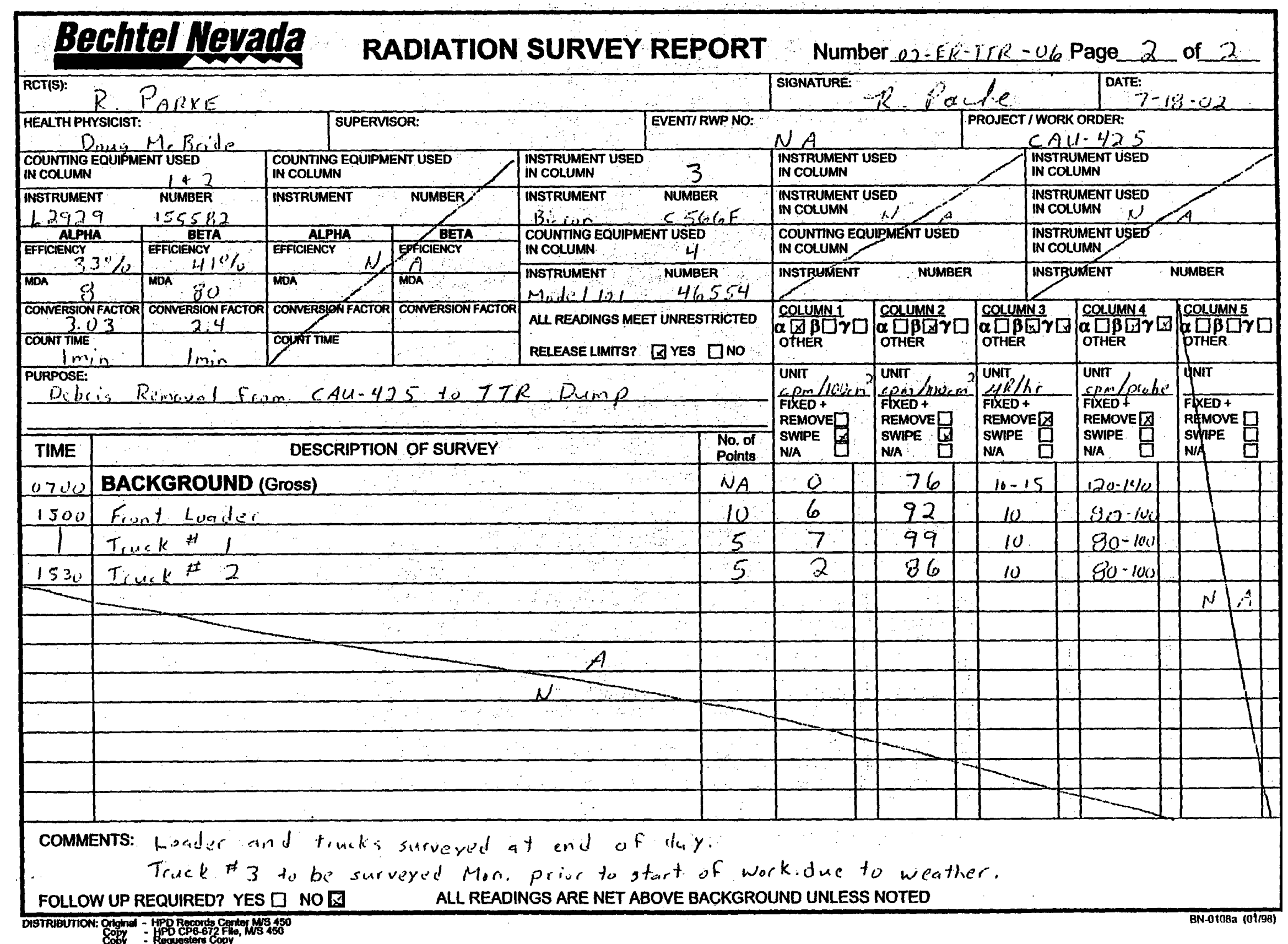




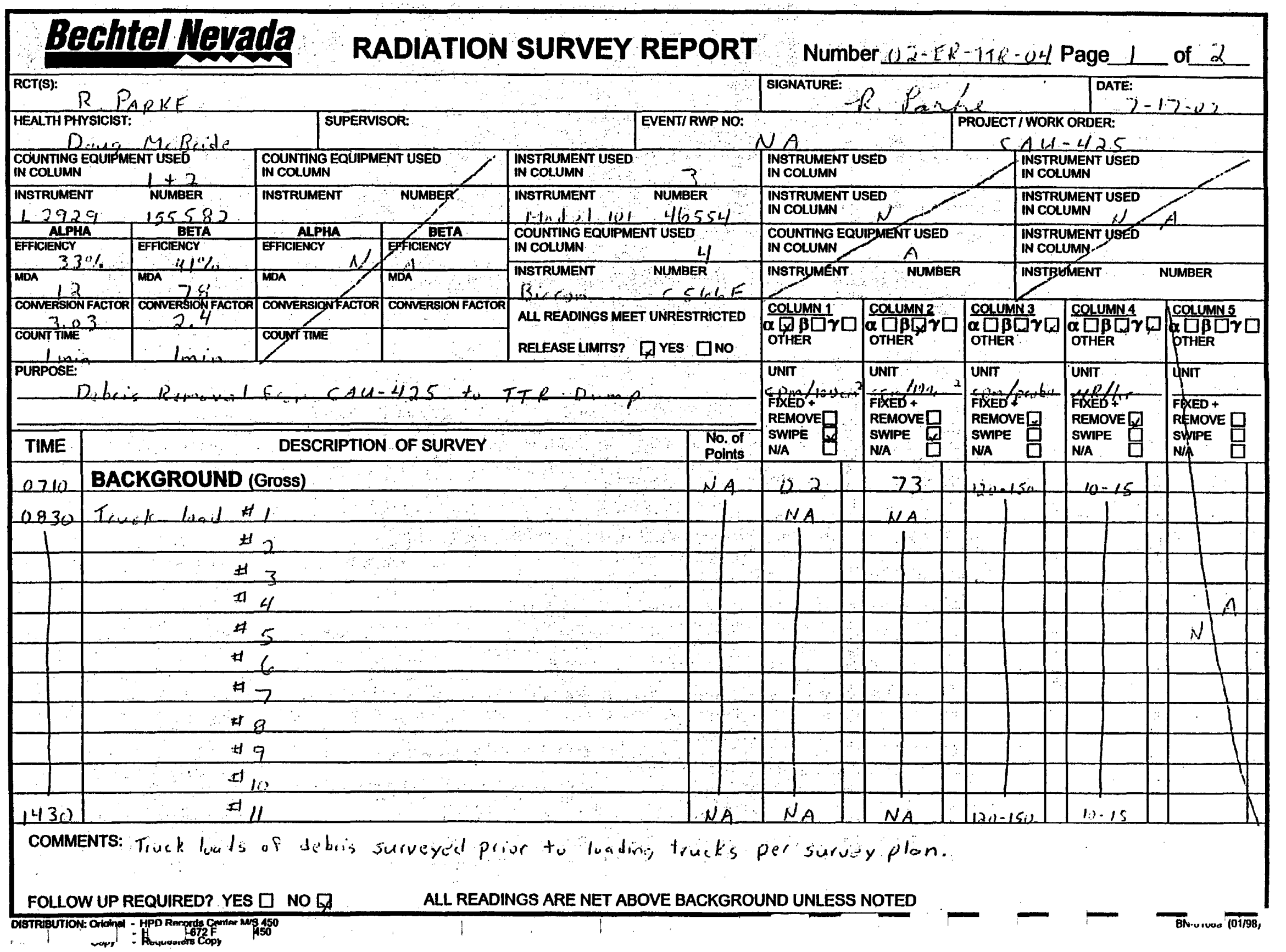




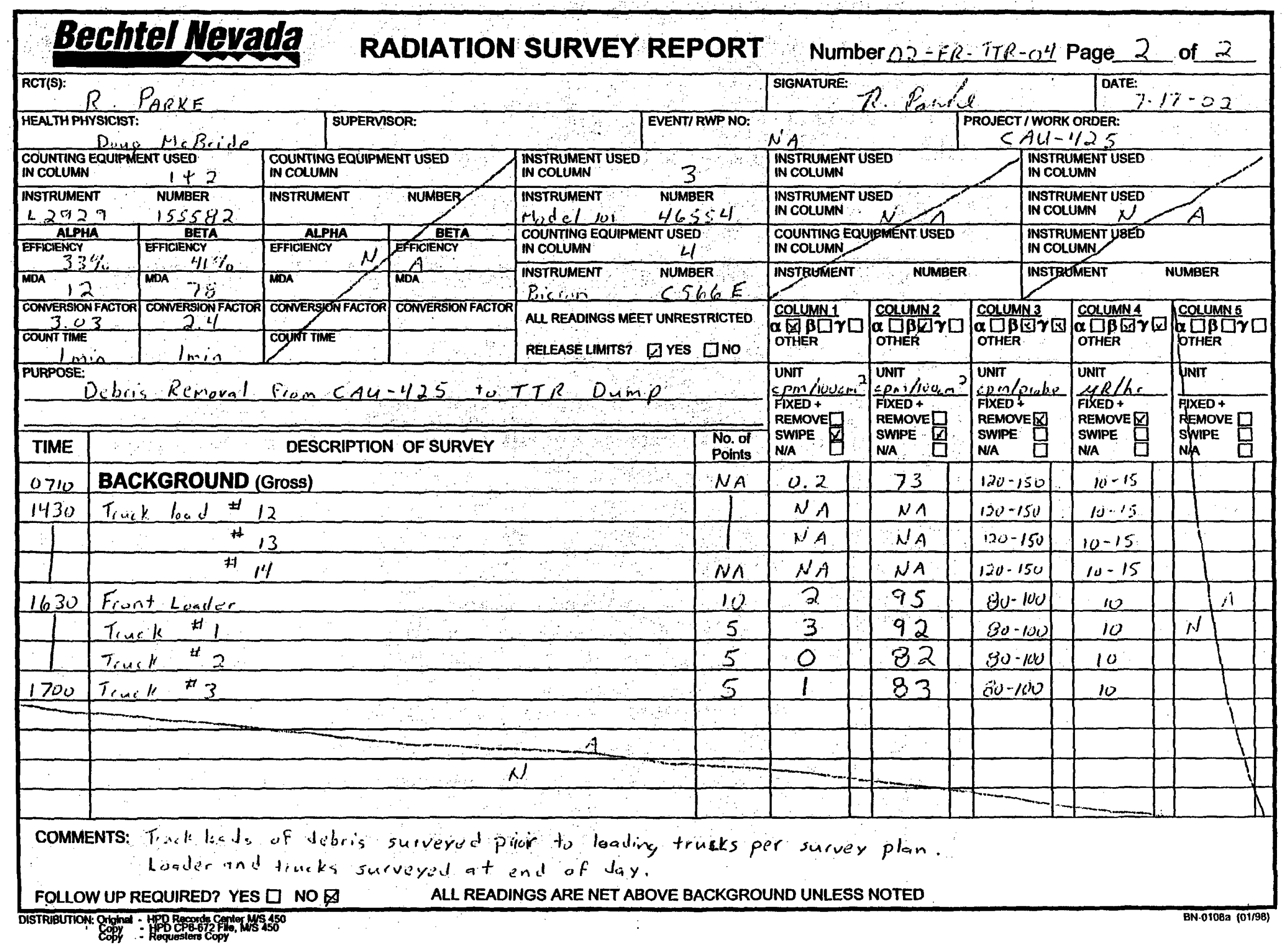




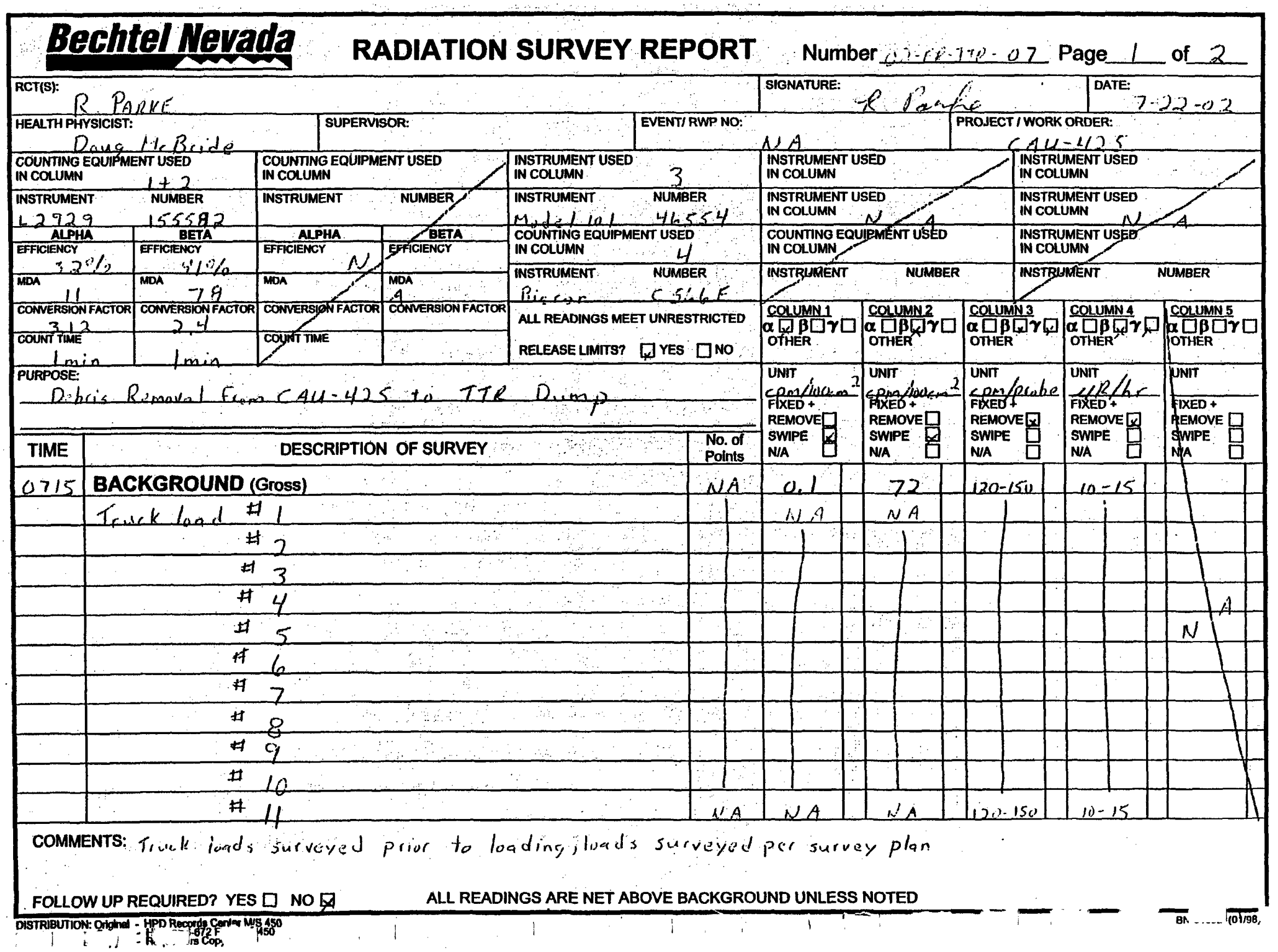




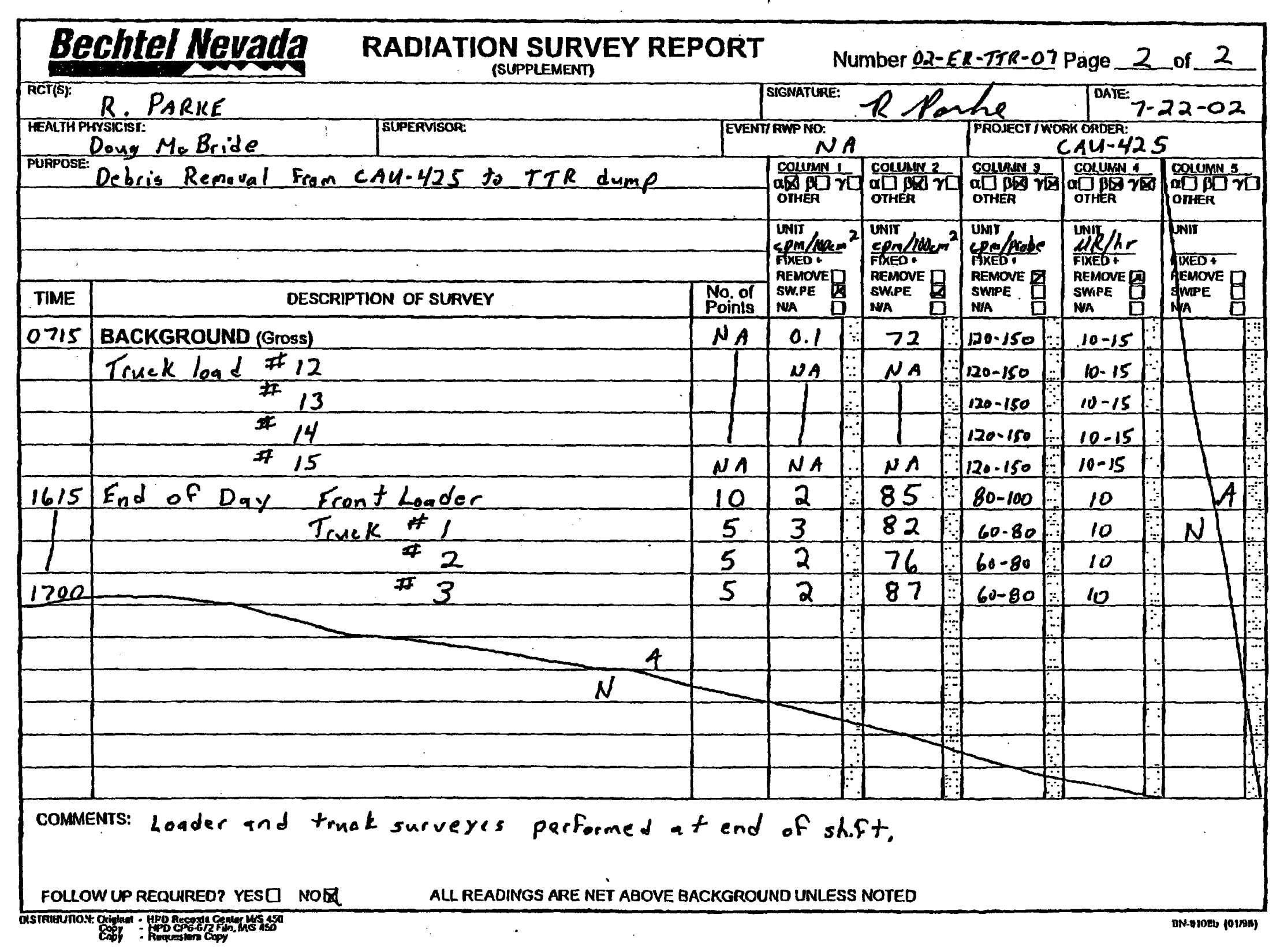




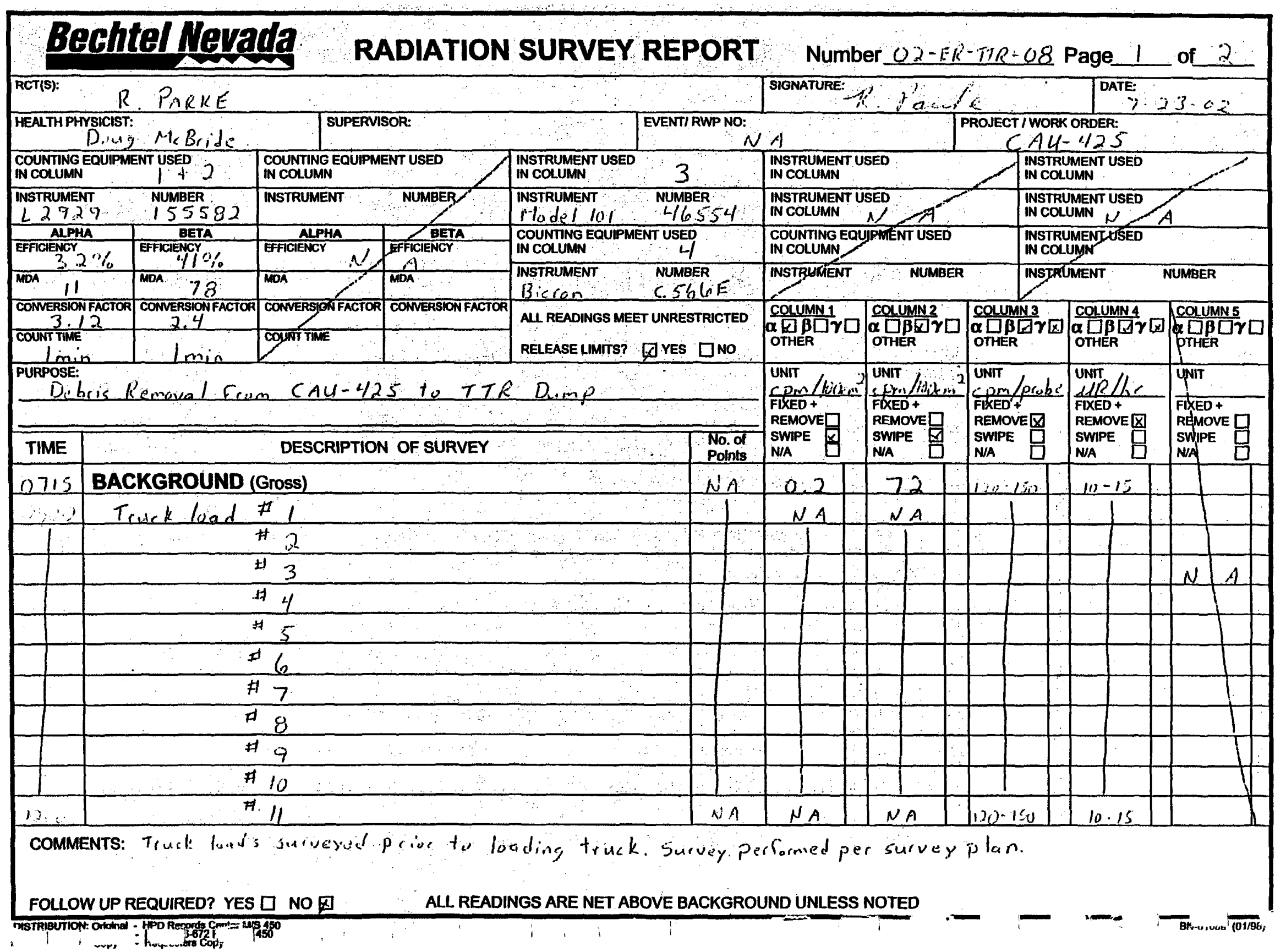




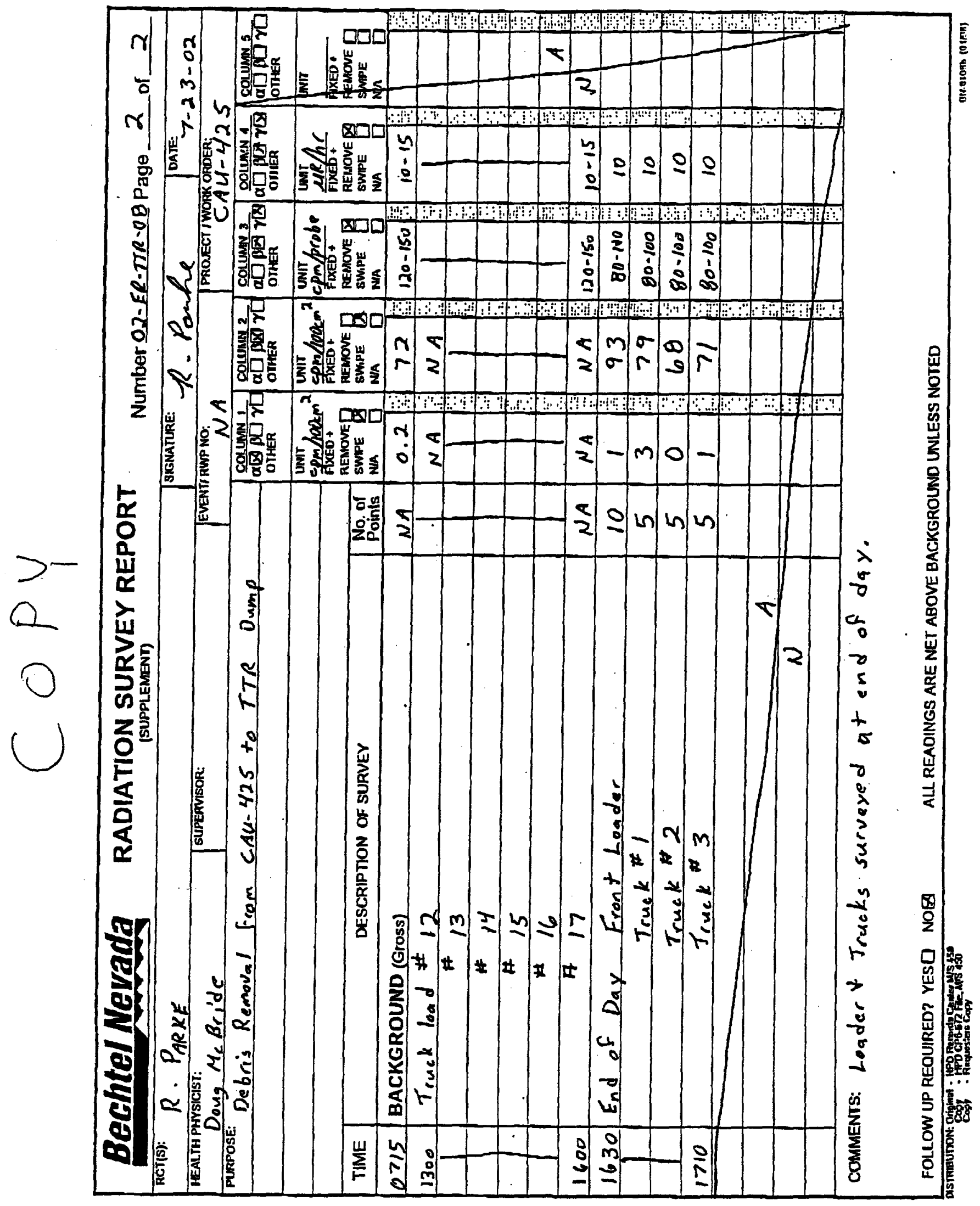




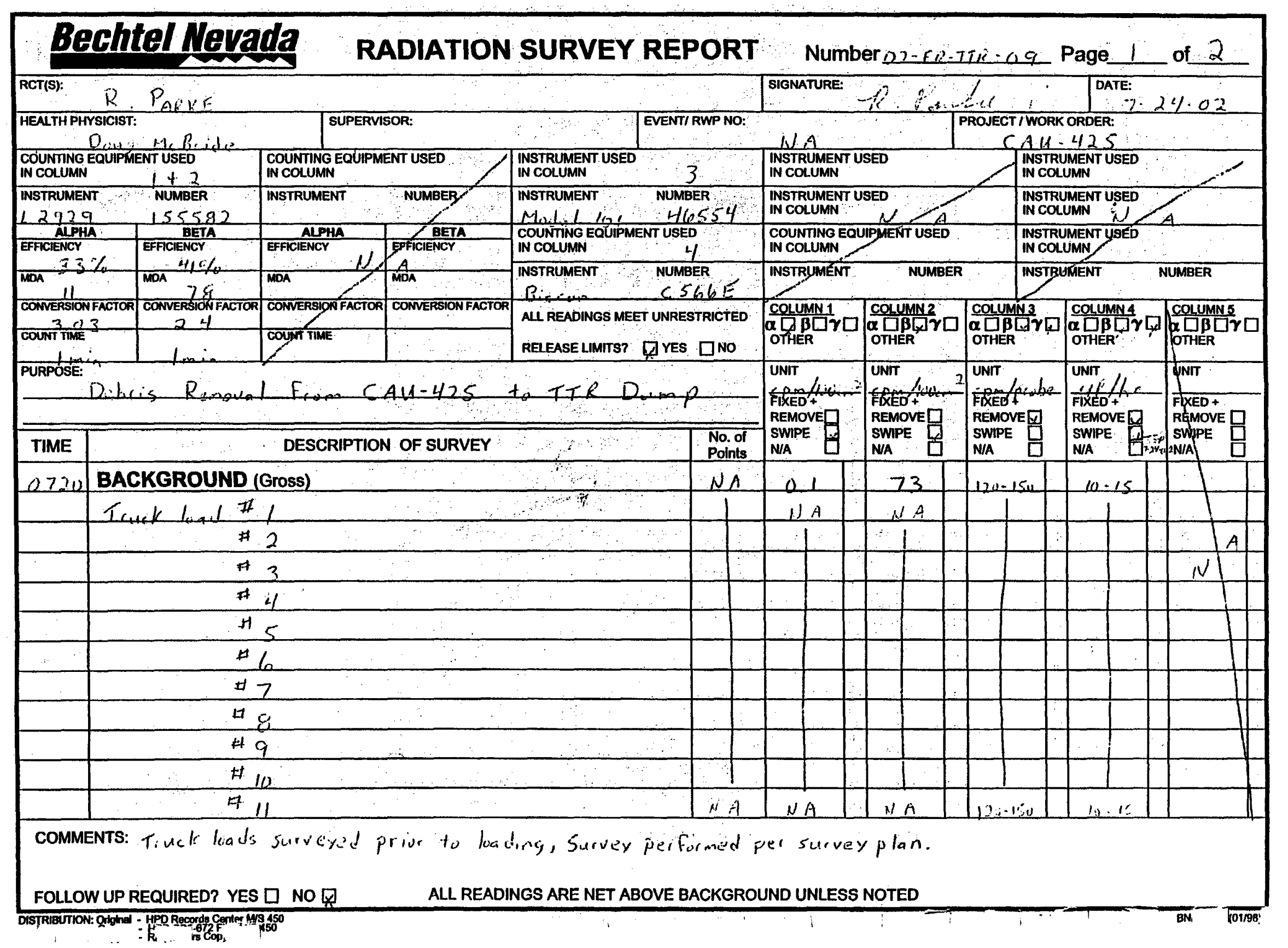




\section{COPY}

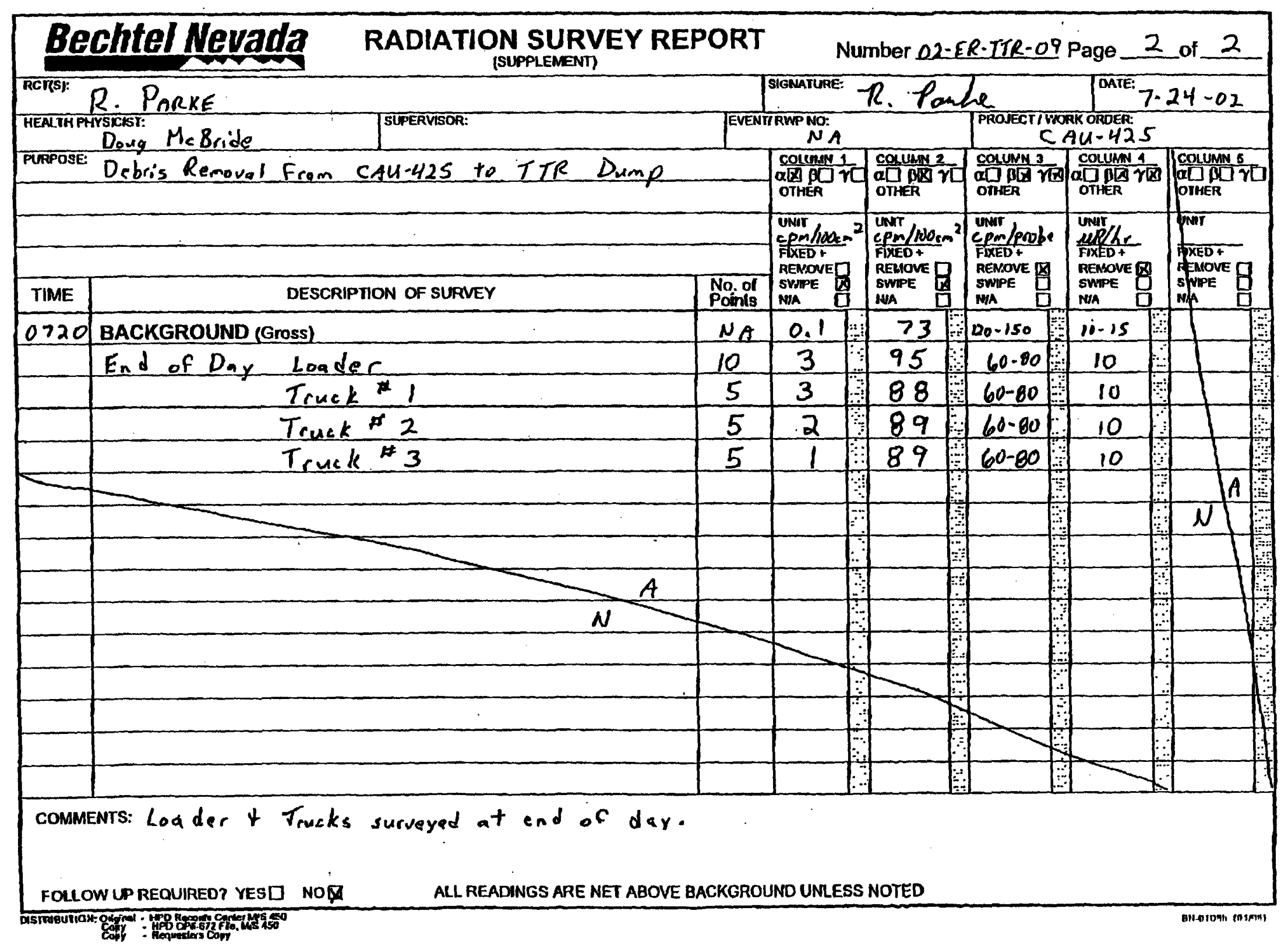




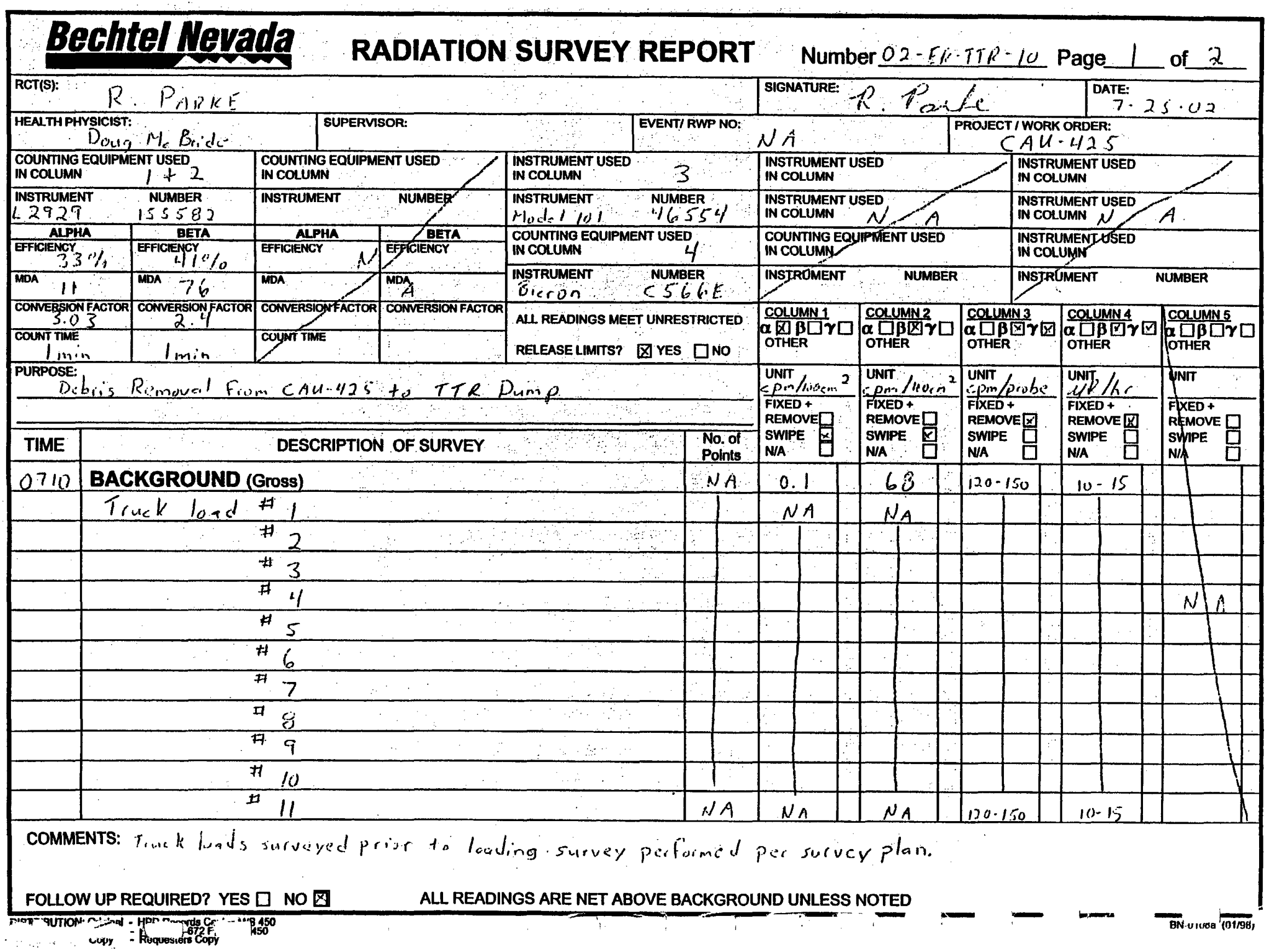




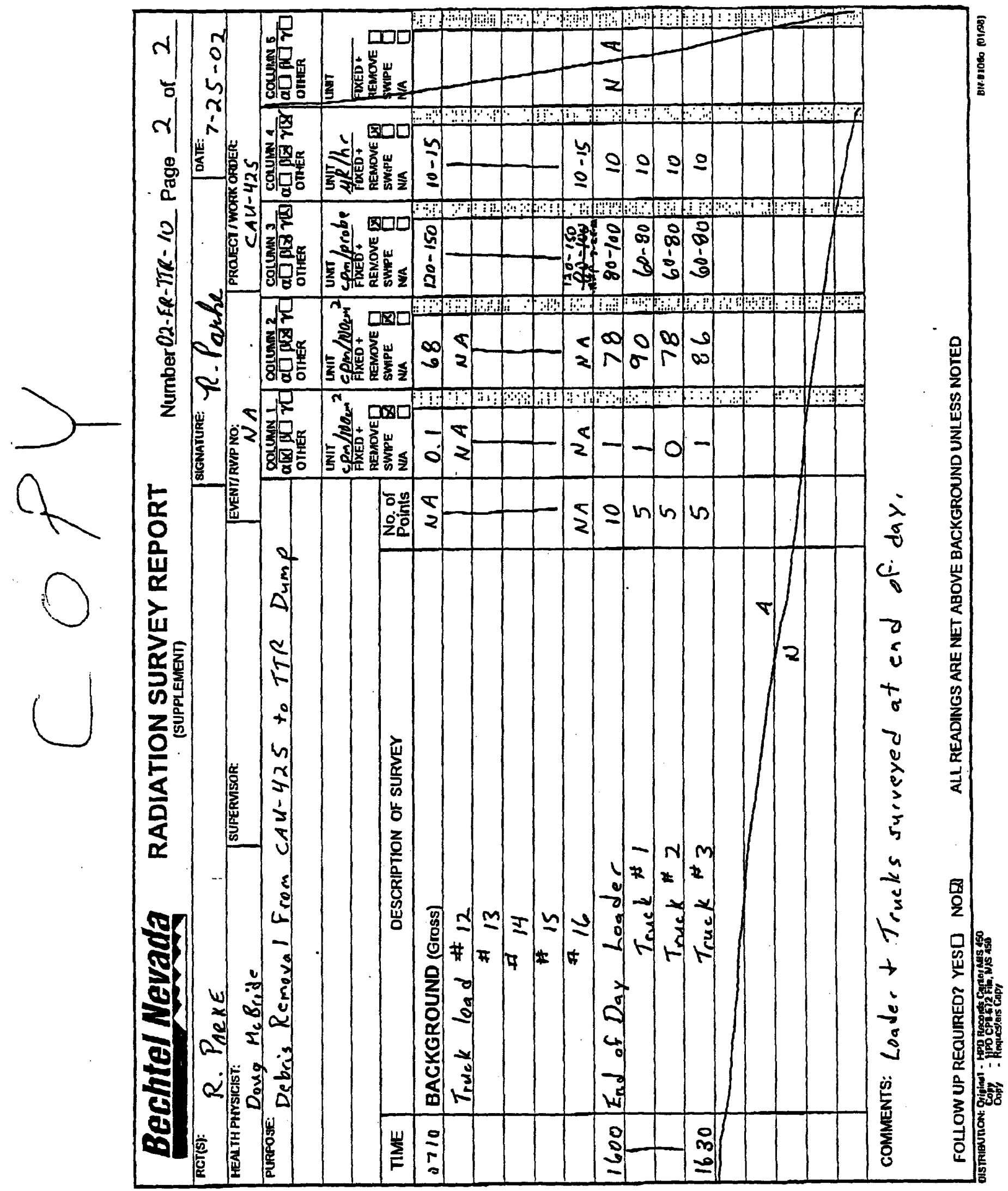




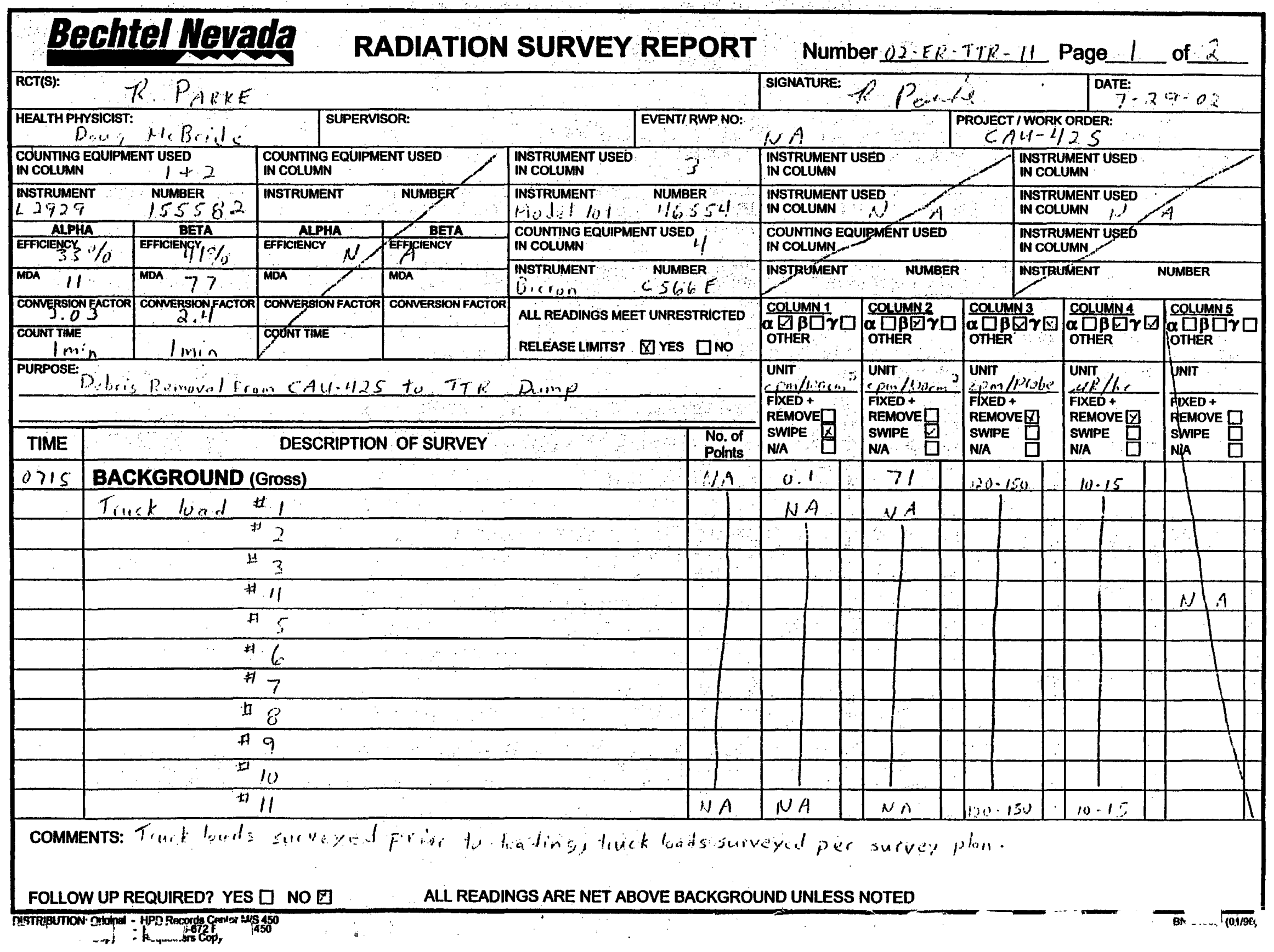




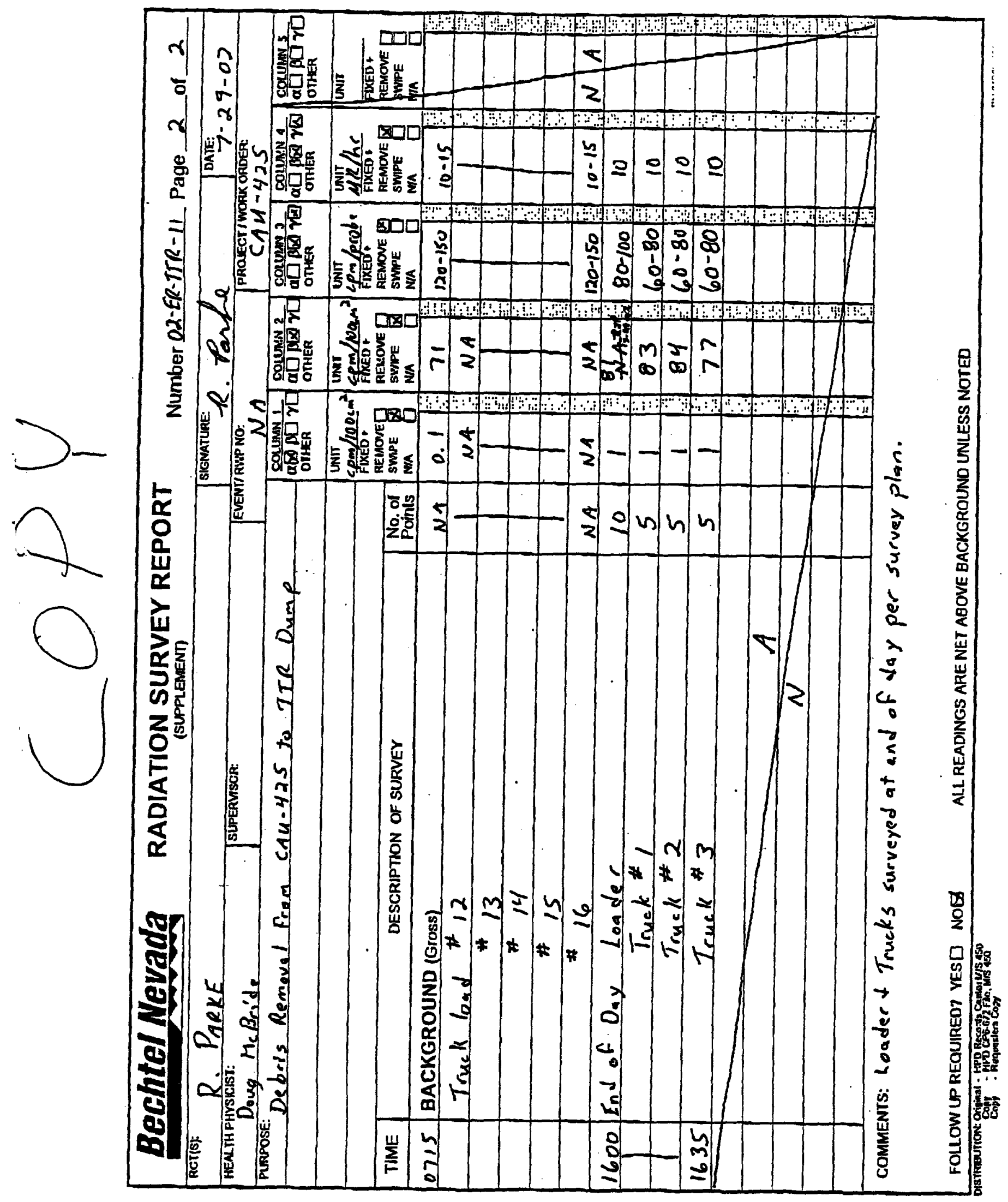




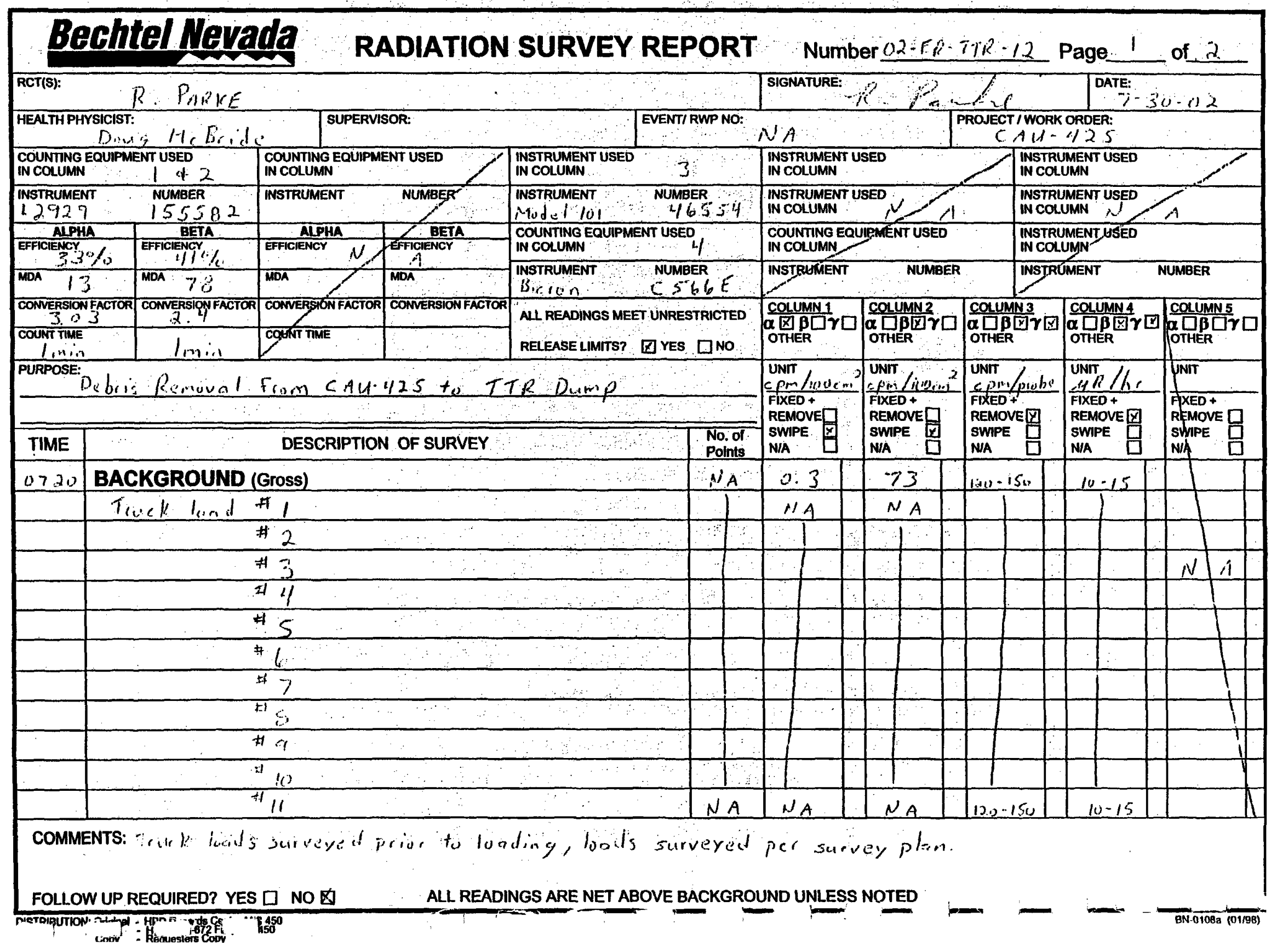




\section{COPY}

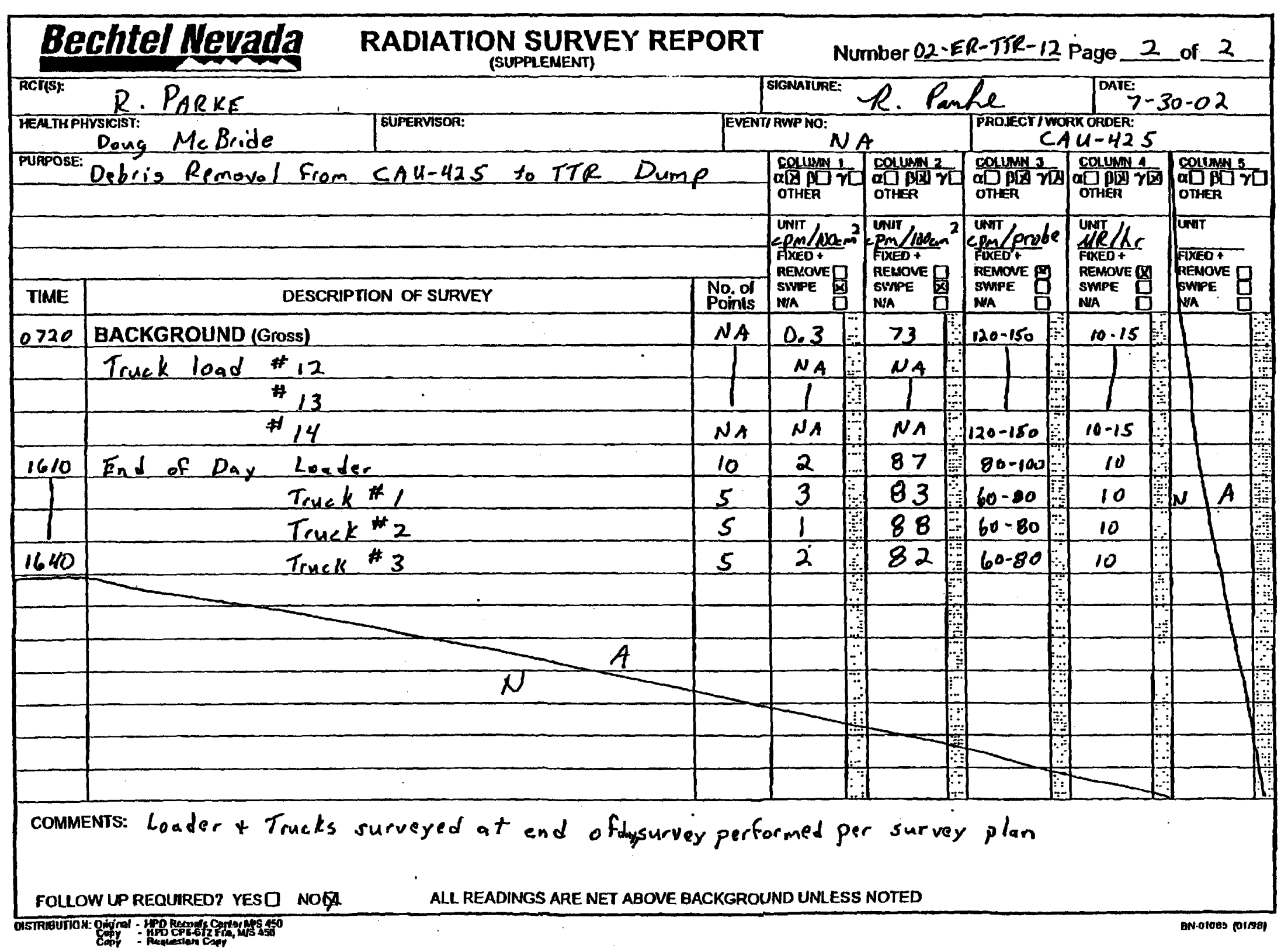




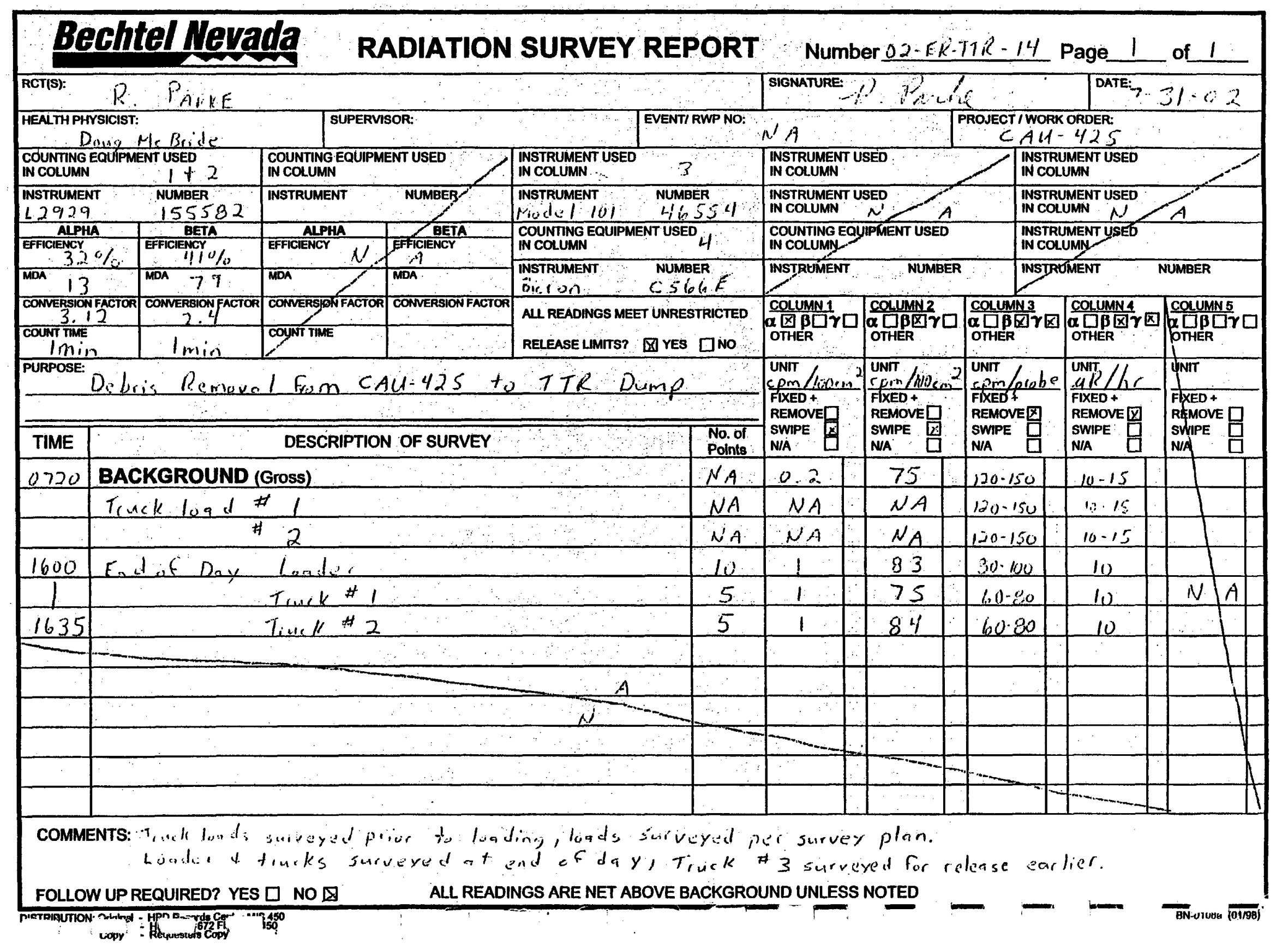




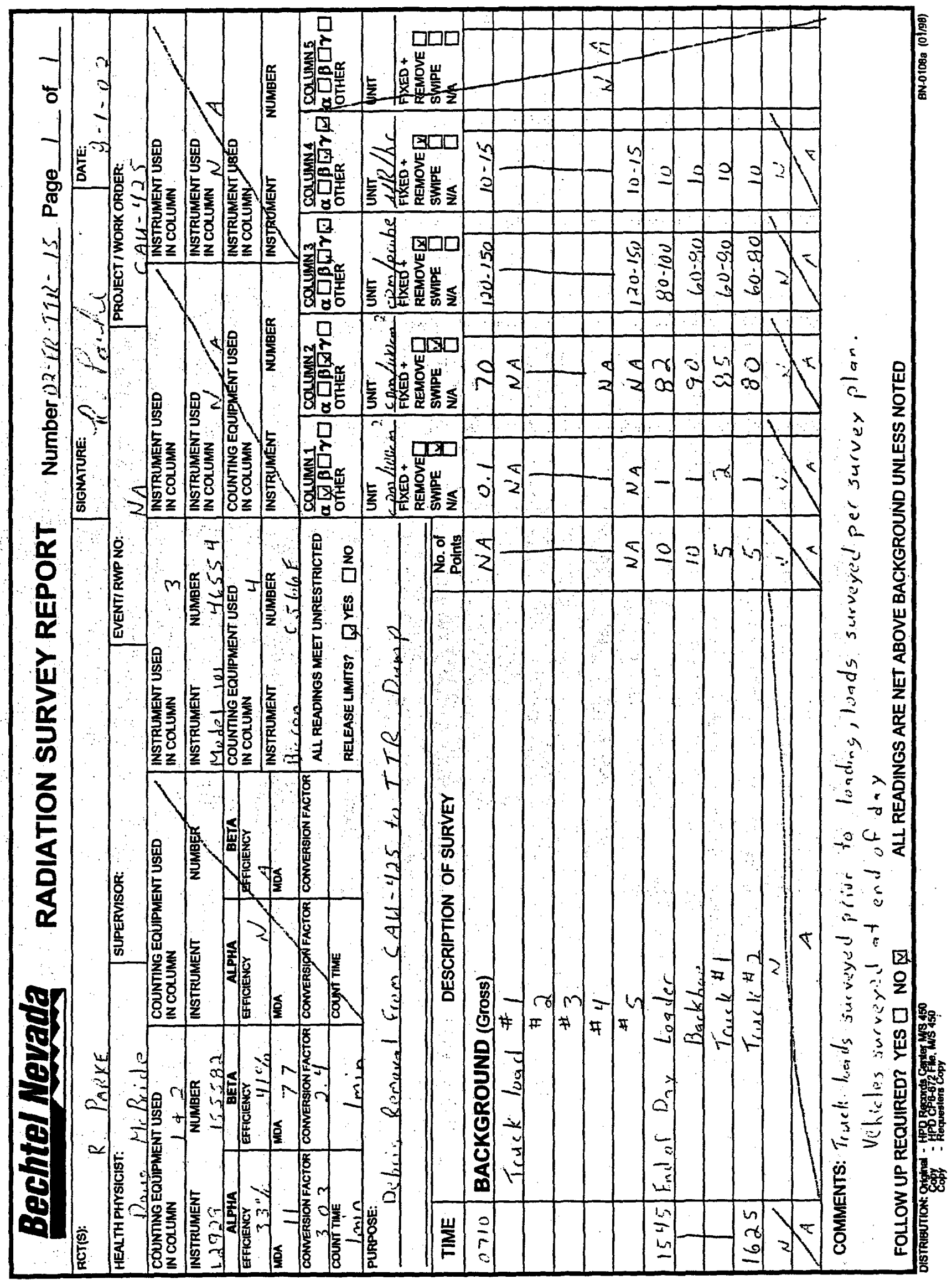




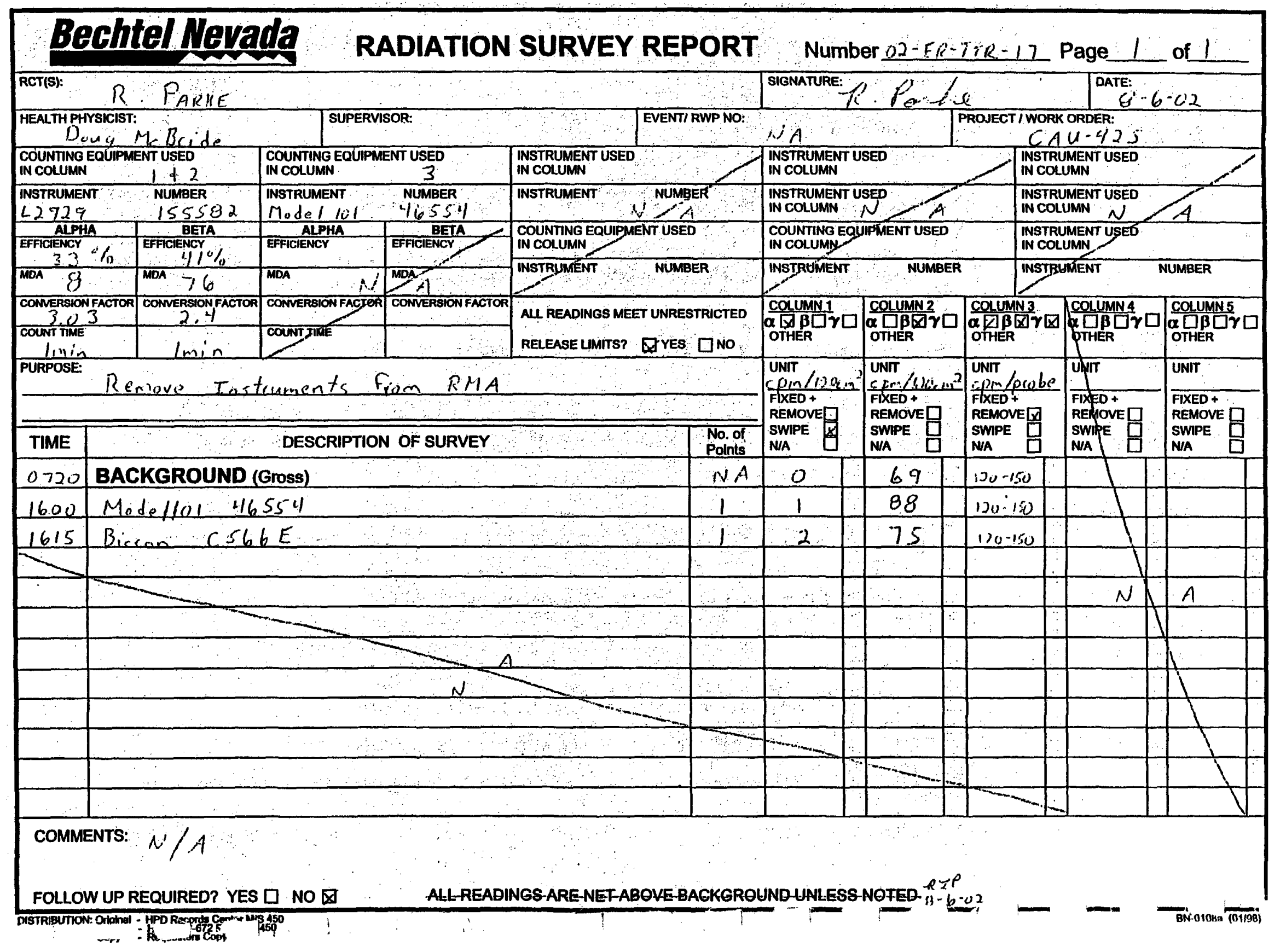




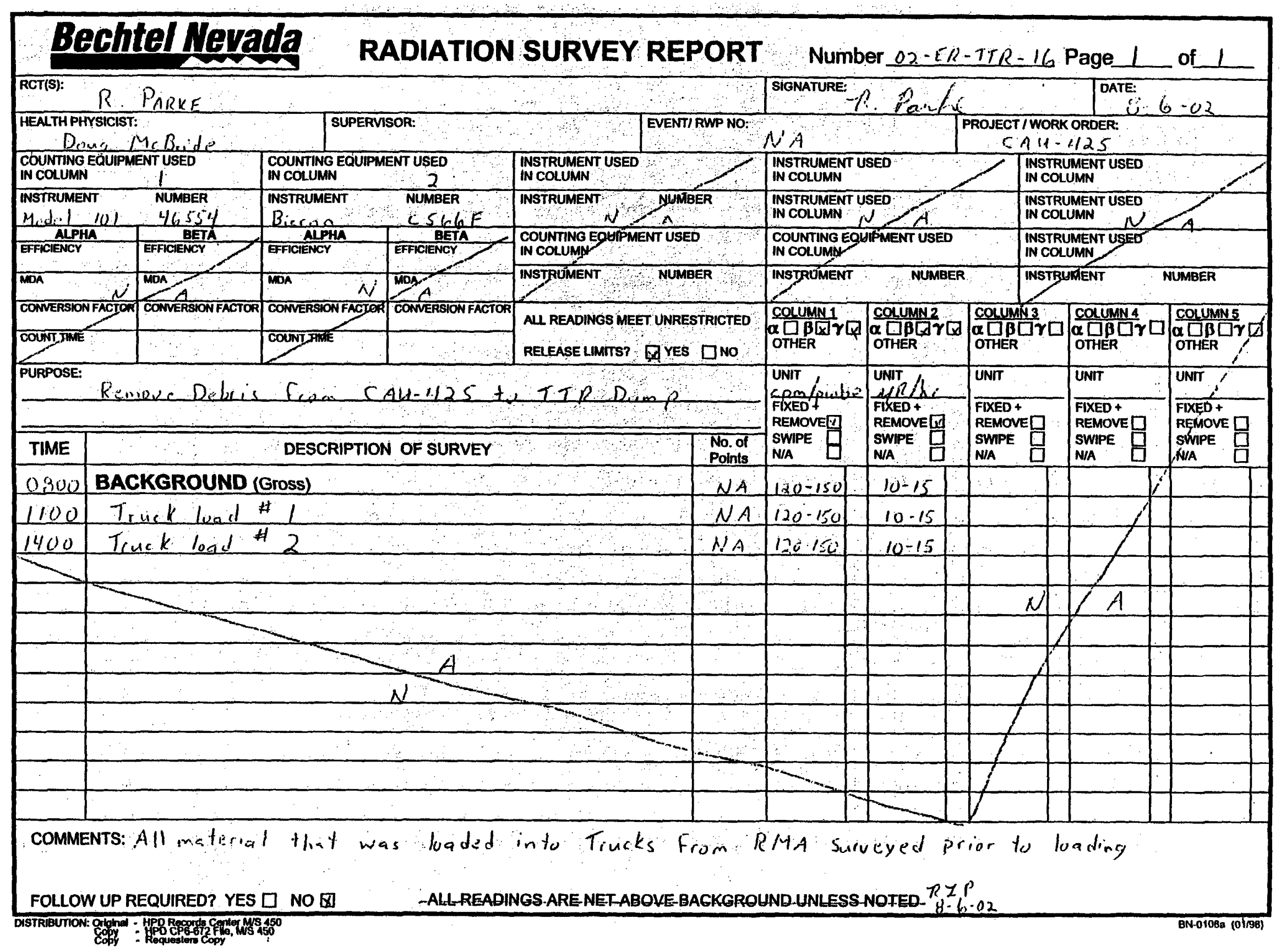


CLOSURE REPORT - CAU 425

Section: Appendix C

Revision: 0

Date: February 2003

THIS PAGE INTENTIONALLY LEFT BLANK 
CLOSURE REPORT - CAU 425

Section: Appendix D

Revision: 0

Date: February 2003

\section{APPENDIX D}

\section{WASTE DISPOSITION DOCUMENTATION}


CLOSURE REPORT - CAU 425

Section: Appendix D

Revision: 0

Date: February 2003

THIS PAGE INTENTIONALLY LEFT BLANK 


\section{HAZTRAK ENTRY CONFIRMATION}

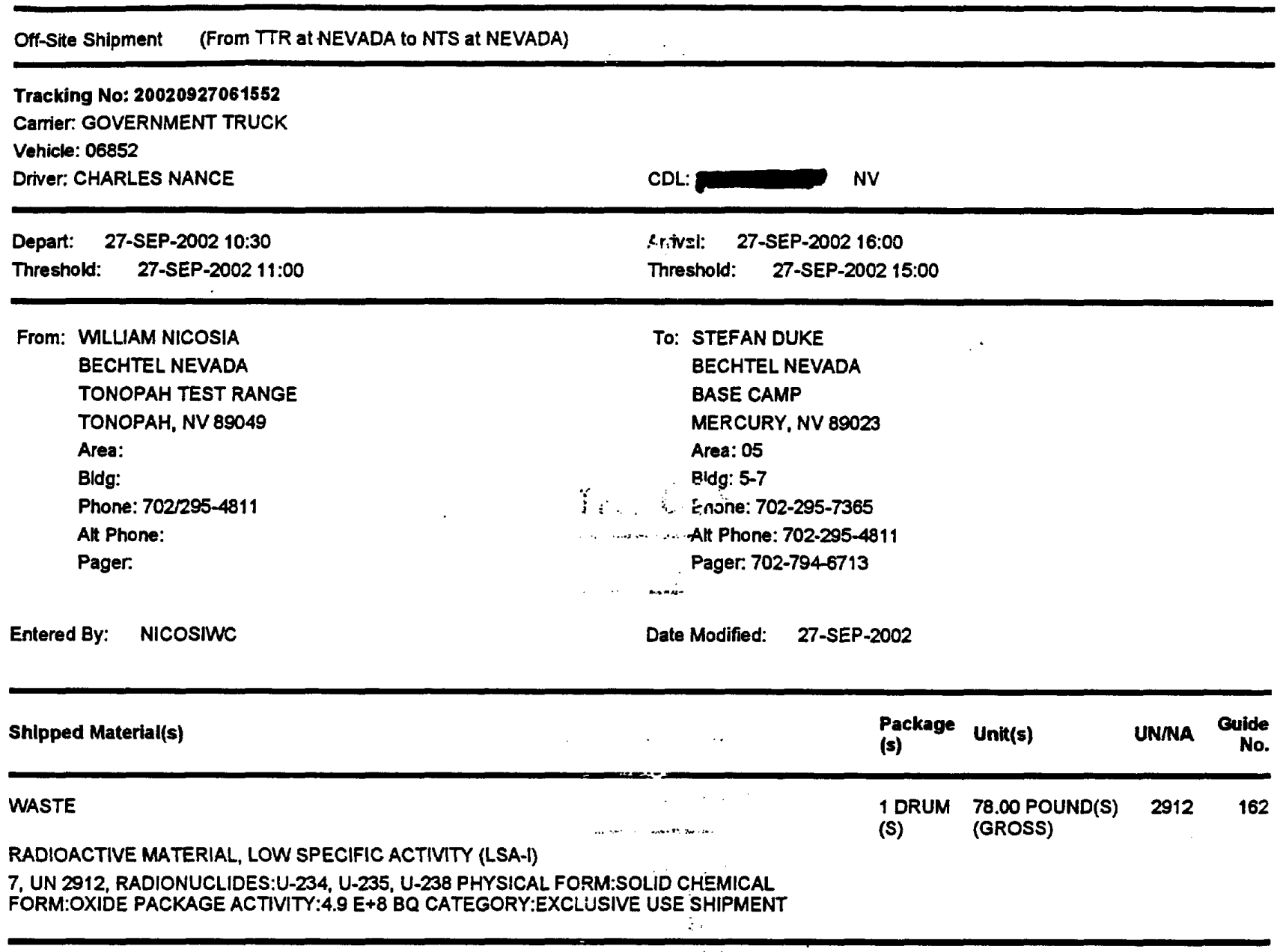

\section{4-Hr Emerger:a: Response Number 702-295-03:1}

Secondary Emergency Response Contact And/Or Comments 
PAGE 1 of 1

\author{
DEPARTMENT OF ENERGY \\ NEVADA OPERATIONS OFFICE \\ RADIOACTIVE MATERIAL SHIPPING RECORD
}

RAMATROL \# 02008

OTHER \#

TO: Bechtel Nevada for US DOE , AREA 5, NEVADA TEST SITE, MERCURY, NV., 89023

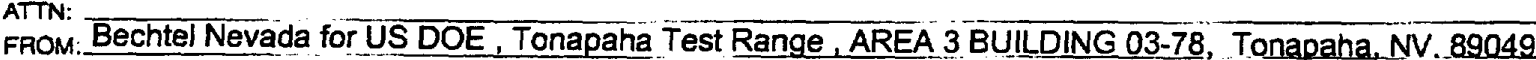

PHONE \# (702) 295-7365

PHONE\#

PROPER SHIPPING NAME RADIOACTIVE MATERIAL,LSA, NOS, (LSA-I)

OIVISION 7 I.D. NUMBER UN2912 GROSS WEIGHT 78 lbs NUMBER OF PKGS. 1

SUBSIDIARY HAZARD N/A

EMERGENCY TELEPHONE NUMBER (702) 295-0311

EMERGENCY RESPONSE GUIDE_ 162

\begin{tabular}{|c|c|c|c|c|c|c|c|c|c|}
\hline $\begin{array}{l}\text { OUIER } \\
\text { PKG. } \\
\text { NO. }\end{array}$ & $\begin{array}{l}\text { Dot } \\
\text { orr }\end{array}$ & $\begin{array}{l}\text { RADIONUCLIDES } \\
\text { (Identilication Number - Optiona) }\end{array}$ & $\begin{array}{l}\text { PHYSICAL } \\
\text { FORM }\end{array}$ & $\underset{\text { FORM }}{\text { CHEMICAL }}$ & 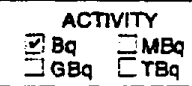 & $A_{1}$ & $A_{2}$ & $\begin{array}{l}\text { FISSILE } \\
\text { EXCEPTED }\end{array}$ & $\begin{array}{l}\text { FISSILE } \\
\text { CONTROLIED }\end{array}$ \\
\hline 1. & & $\mathrm{U}-238$ & SOLID & OXIDE & $4.42 E+8$ & & $\bar{x}$ & N/A & N/A \\
\hline 2. & & $\mathrm{U}-235$ & SOLID & OXIIDE & $7.14 E+6$ & & $\underline{x}$ & N/A & N/A \\
\hline 3. & & $\mathrm{U}-234$ & SOLID & OXIDE & $4.13 E+7$ & & $\bar{x}$ & N/A & N/A \\
\hline 4. & & & & & & & & & \\
\hline 5. & & & & & & & & & \\
\hline
\end{tabular}

Outer Container(s) Surveyed by: Mike Withers

Date $\underline{09 / 27 / 02}$

\begin{tabular}{|c|c|c|c|c|c|c|}
\hline $\begin{array}{l}\text { OUTEA } \\
\text { PKG. } \\
\text { NO. }\end{array}$ & $\begin{array}{r}\text { CONTACT } \\
-m S / h=\eta \\
\beta \cdot \gamma=\eta \\
\end{array}$ & 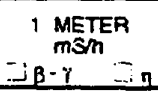 & $\begin{array}{l}\text { SWIPE - DPN } 100 \mathrm{~cm}^{2} \\
\mathrm{BQ} / 100 \mathrm{~cm}^{2} \\
\mathrm{~B}-\mathrm{y}=\alpha\end{array}$ & $\begin{array}{l}\text { TRANS- } \\
\text { POAT } \\
\text { INDEX }\end{array}$ & $\begin{array}{l}\text { RADIOACTIVE } \\
\text { TYPE LABELING } \\
\text { (2REQUIRED) }\end{array}$ & $\begin{array}{l}\text { CERTIFICATION } \\
\text { SPECORDOT } \\
\text { OR NACE: }\end{array}$ \\
\hline 1. & * & & $<\quad<$ & & & \\
\hline 2. & & & $<$ & & & \\
\hline 3. & & & $\leq$ & & & \\
\hline 4. & & & $<$ & & & \\
\hline 5. & & & $<$ & & & \\
\hline
\end{tabular}

Remarks or Special Handling/Transport Requirements "SEE ATTACHED SURVEY

TRANSPORT MODE HIGHWAY CARRIER GOVERNMENT TRUCK

VEHICLE NUMBER G63 SEAL NUMBER (s) N/A

SECURITY CLASSIFICATION UNCLASSIEIED PREPARED BY STEEAN DUKE

COURIERED N/A EXCLUSIVE USE YES

DATE $09 / 23 / 02$

PLACARDS OFFERED

SPECIAL FORM CERTIFICATION CURAENT $\angle$ YES or $\nabla$ NA initials

PACKAGE CERTIFICATION CURRENT $\because$ YES or $\square$ NA initials

RADIOACTIVE MATERIAL LICENSE CURRENT $\nabla$ YES or $L$ NA initials

Centification:

This is to certify that the above named materials are properly classified, described, packaged, marked, and labeled, and in proper condition for transportation, according to the applicable regulations of the Department of Transportation. CEATIFIED BY: DATE $1-27-02$

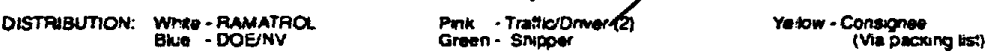
NW. $152(799)$ 


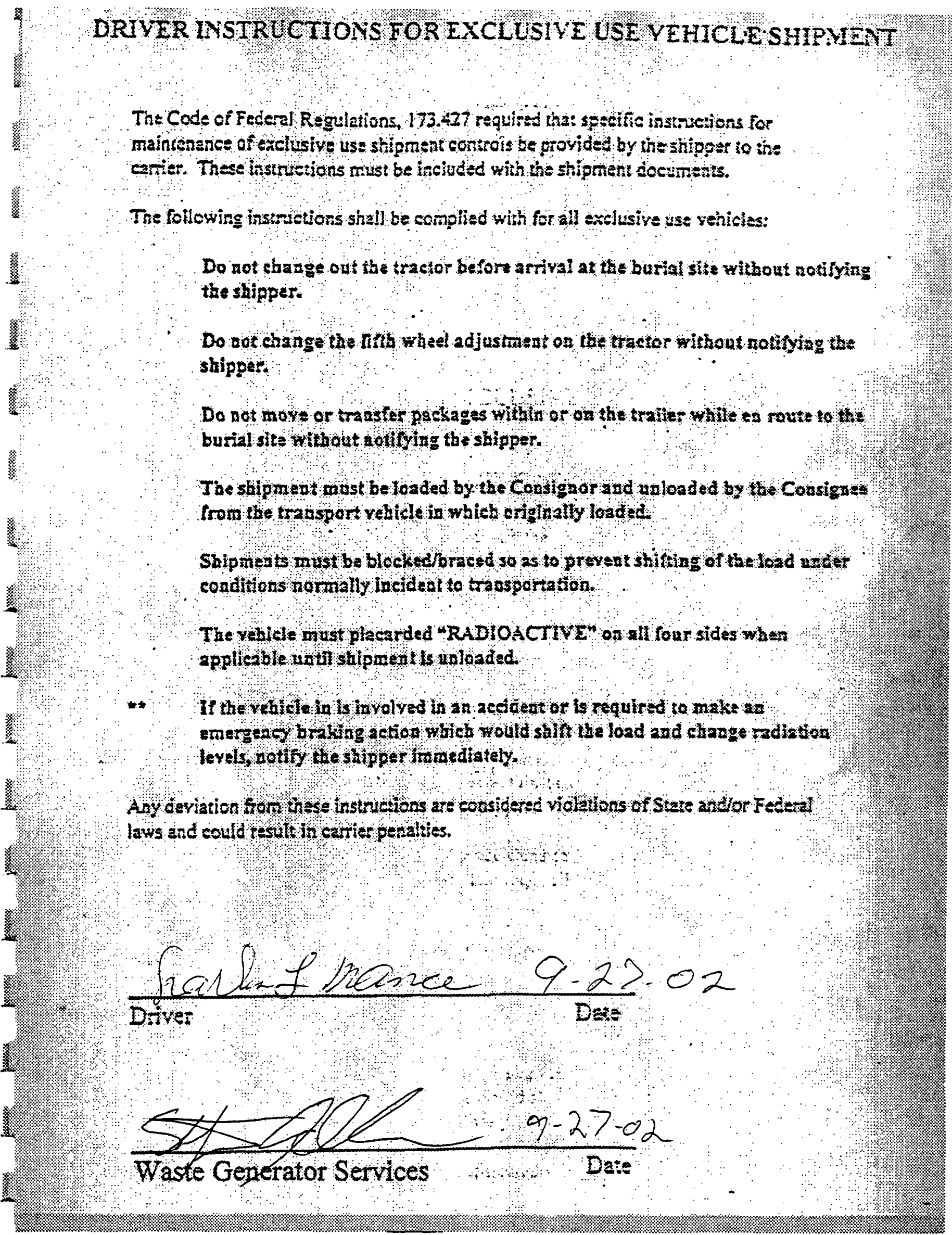




\section{NTS On-Site HazMat Transfer - Published}

Tracking No: DPL03008

Carrier. GOVERNMENT TRUCK

Vehicle: G6306852 NV

Driver. CURTIS STEVENS

Depart: 23-JAN-2003 09:00
CDL

NV

Arrival: $\quad 23-J A N-2003$ 12:00

From: STEFAN DUKE

BECHTEL NEVADA

BASE CAMP

MERCURY, NV 89023

Area: 05

Bldg: 5-7

Phone: 702-295-7365

At Phone: $702-295-4811$

Pager: 702-794=6713

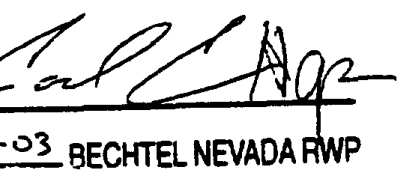

TO: MARK KRAUSS

BECHTEL NEVADA

BASE CAMP

MERCURY, NV 89023

Area: 05

Bldg: 5-7

Phone: 702-295-6808

At Phone: 702-295-6811

Pager.

Entered By:

\section{PATF $1-23-03$ BECHTEL NEVADA RWP}

Date Modified: 22-JAN-2003

\begin{tabular}{llll} 
Shipped Material(s) & $\begin{array}{l}\text { Package } \\
\text { (s) }\end{array}$ & Unit(s) & $\begin{array}{l}\text { UN/NA } \\
\text { Uuide } \\
\text { No. }\end{array}$ \\
\hline WASTE & $\begin{array}{l}\text { 1 DRUM } \\
\text { (S) }\end{array}$ & $\begin{array}{l}69.40 \text { KILOGRAM } \\
\text { (S) (GROSS) }\end{array}$ & 2912 \\
\hline
\end{tabular}

RADIOACTIVE MATERIAL, LOW SPECIFIC ACTIVITY (LSA), N.O.S.

7, UN-2912. RADIONUCLIDES:U-234, U-235, U-238 PHYSICAL FORM:SOLID CHEMICAL FORM:OXIDE PACKAGE ACTIVITY:4.904E8BQ CATEGORY:EXCLUSIVE USE SHIPMENT

\section{4-Hr Emergency Response Number 702/295-0311}

Secondary Emergency Response Contact And/Or Comments ADAM DAEGORN 702-295-4779

\section{EMERGENCY RESPONSE}

$\begin{array}{cc} & \text { By Phone } \\ 702-295-0311 & \\ \text { By Radio } & \\ \ldots \quad \text {.. MAYDAY - MAYUAY - MAYDAY' }\end{array}$

This is to certify that the above-named materials are properly classified, described, packaged, marked, placarded, and labeled and are in proper condition for transportation according to the applicable regulations of the U.S Department of Transportation. As a signatory I cerfify that I have been trained and tested to the requirements of 49 CFR, Part 172-700.
In the event of an incident involving Hazardous Material:

1. Gather HazMat shipping papers and NAER Guidebook

2. Isolate the immediate area

3. Assess the situation:

a. Fire, Spill, or Leak?

b. People, Property, or the Environment at risk?

4. Contact On-site Emergency Response Personnel

5. Reference On-Site HazMat Transfer Tracking Number 
Authorized Signature: Date: $\frac{1-23-63}{1-23-03}$ Time: 0915 
Th= Code of Federal Regulations, 173.427 requirsed that specific insthetions for

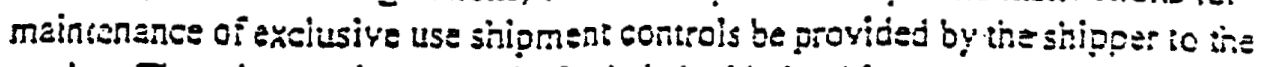
cartier. These instruetions must be incluced with the stipment decuments.

The following instrations shall be complied with for all exclusiye use yehieles:

Do not change out the tractor beion arriyal a? the burial sits without notiyisg the shipper.

Do sot change the If th whel adjustrasat on the tractor without notiying the shipper.

Do not moye or transfer packages within or on the trailer while es route to the burial site without zotifying the shipper.

The shipment must be loaded by the Consignor and unloared by the Consignes from the transport vehicle in which originally loaded.

Shipmen ts must be blocked/braced so as to preyent shitting of the load under conditions normally incident to trassportation.

The vehicle must placardad "RADlOACTIVE" on all four sides when appliezble until shipment is unloaded.

* If the vehicle in is involved in an aceident or is requirad to maks an emerzency braking action witich would shift the load and change radiztion leyels, notify the shipperimmediately.

Any deviation from these instruetions are considersd vioiations of Sia:e andior Fadera? laws and could pesult in cartier penalties.
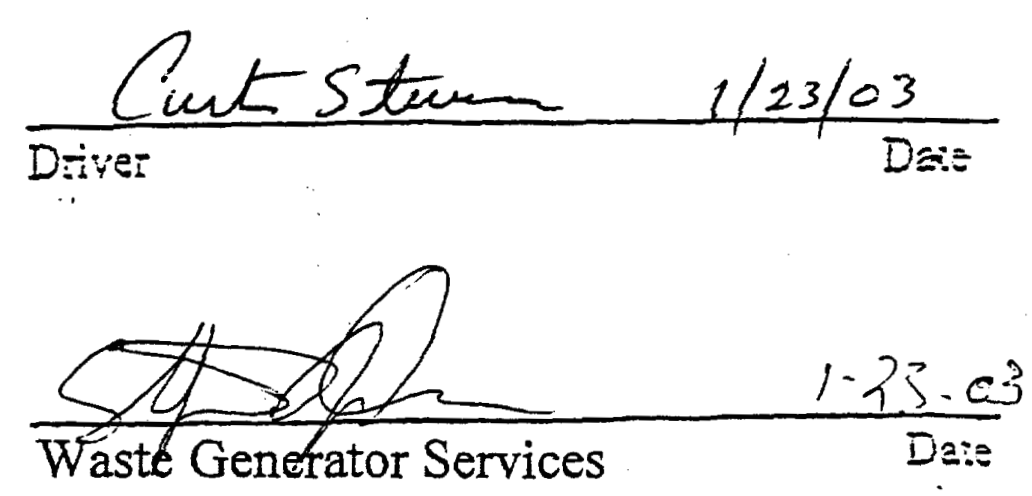


\section{OPL 03008}

\section{Low-Level Waste Certification}

I certify that containers: 034005

do not contain hazardous waste as defined in Title 40 CFR 261 or state of Nevada hazardous waste regulations:

1. According to the results of test performed in accordance with the requirements as specified in Subpart C of Title 261; and/or

2. According to the supporting documentation provided to me about the materials and processes that produced this waste.

To the best of my knowledge, I believe the information I have submitted is true, accurate, and complete.

Dennis Swick/alegh

Generator Waste Certification Official (Print Name/Sign)
$1 / 23 / 03$

Date 
Package Storage and Disposal Request

Shipment Number: DPL03008

Date: 22-Jan-2003

Package No:

Container Code:

External Volume $\left(m^{\wedge} 3\right)$ 3.750E-01

Waste Volume $\left(m^{\wedge} 3\right)$ : 2.260E-01
Prepared By: Stefan Dike

Manifest Number: Comment:

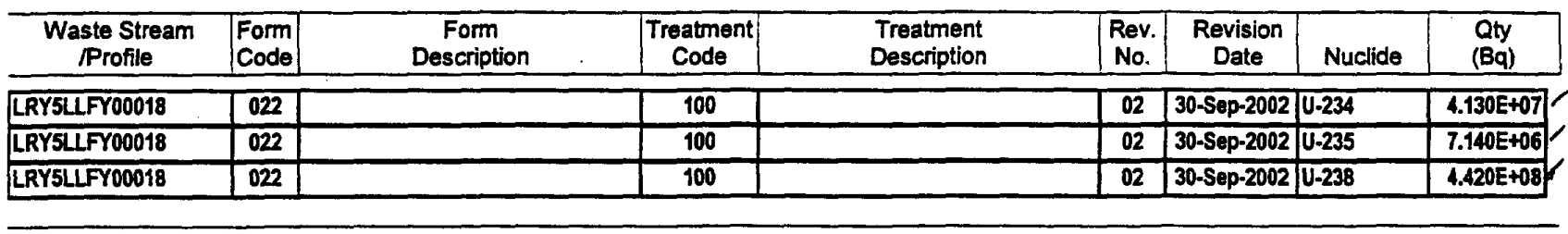

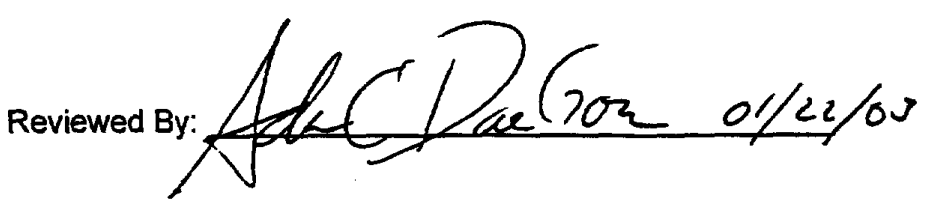

Page 1 of 1 


\section{Certificate of Disposal}

This is to certify that the, Waste Stream No., LRY5-LLFY00018 package number 03L005, was shipped and received at the Nevada Test Site Radioactive Waste Management Site in Area 5 for disposal as stated below.

Stefan Duke

Shipped by

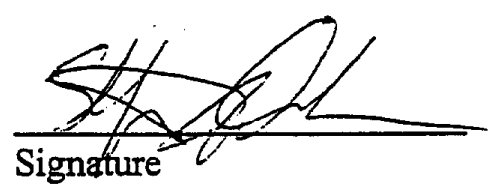

Dougias K CiARK Received by

A $\angle N C L$ Signature
Bechtel Nevada Waste Generator Services

Organization

RLiMC

Organization

Title

ENGINEER

Date

$1.23 \cdot 03$

Title

Scientist

1.23003

Date

$23-J A N-2003$ 


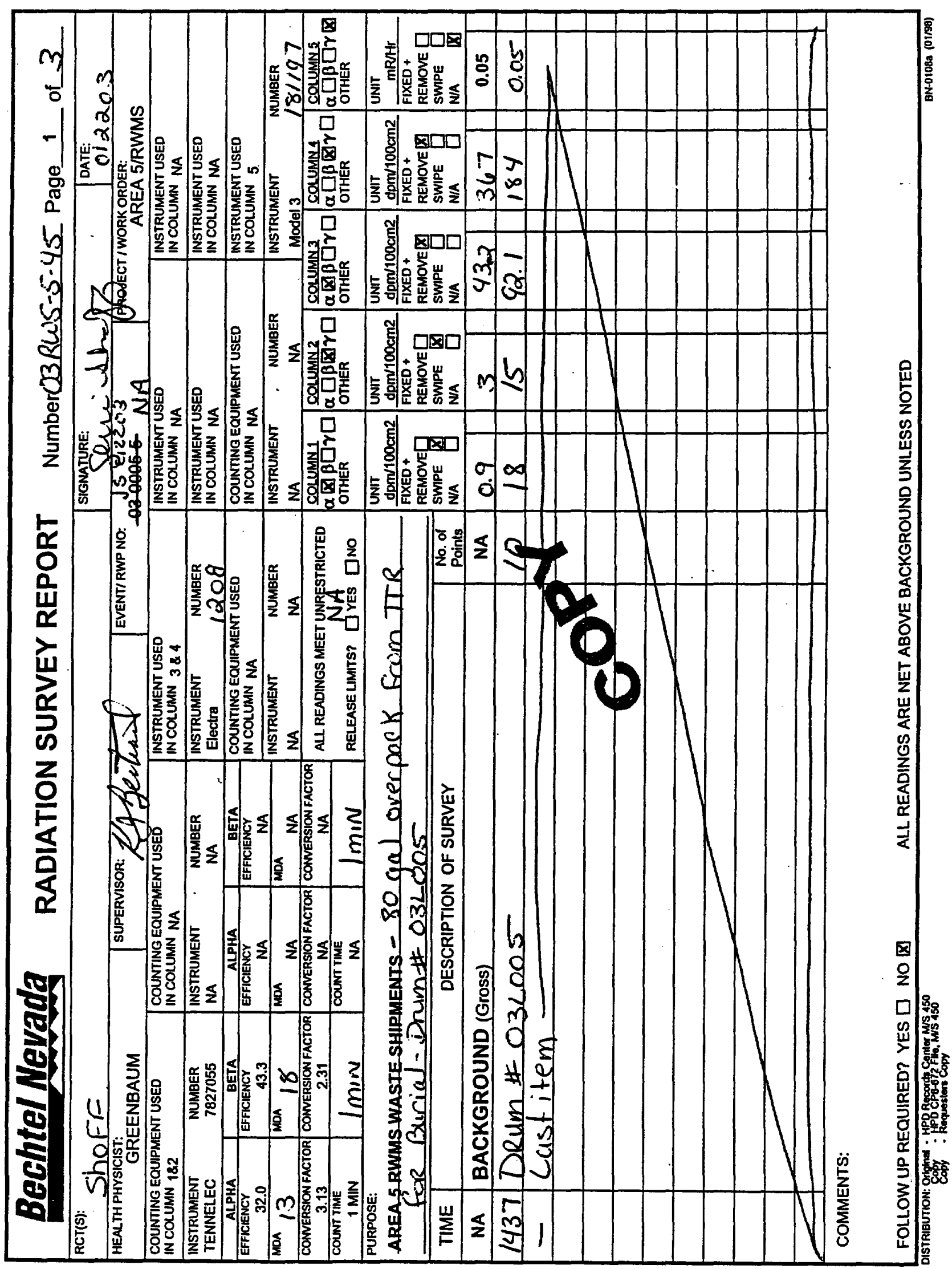




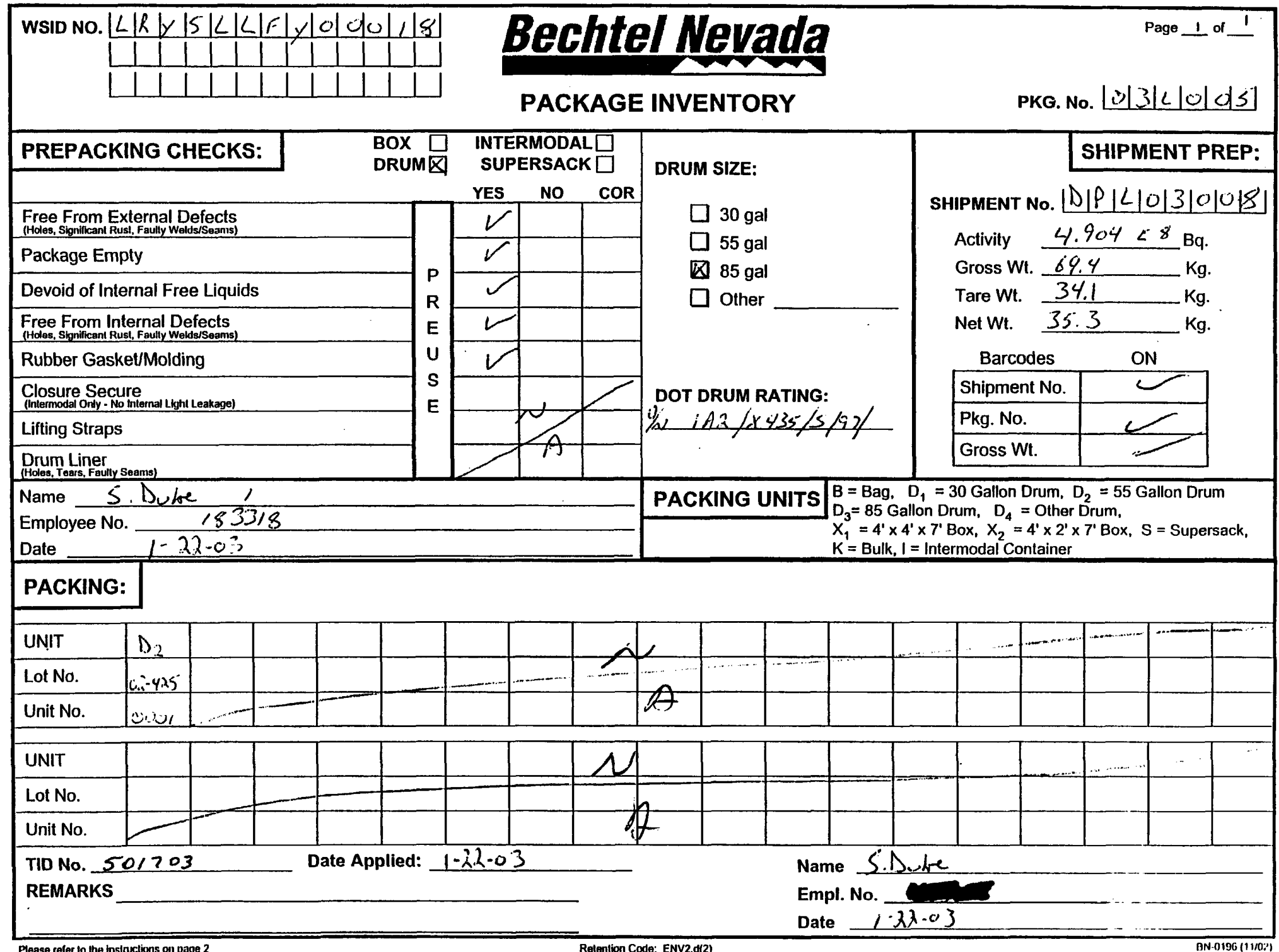




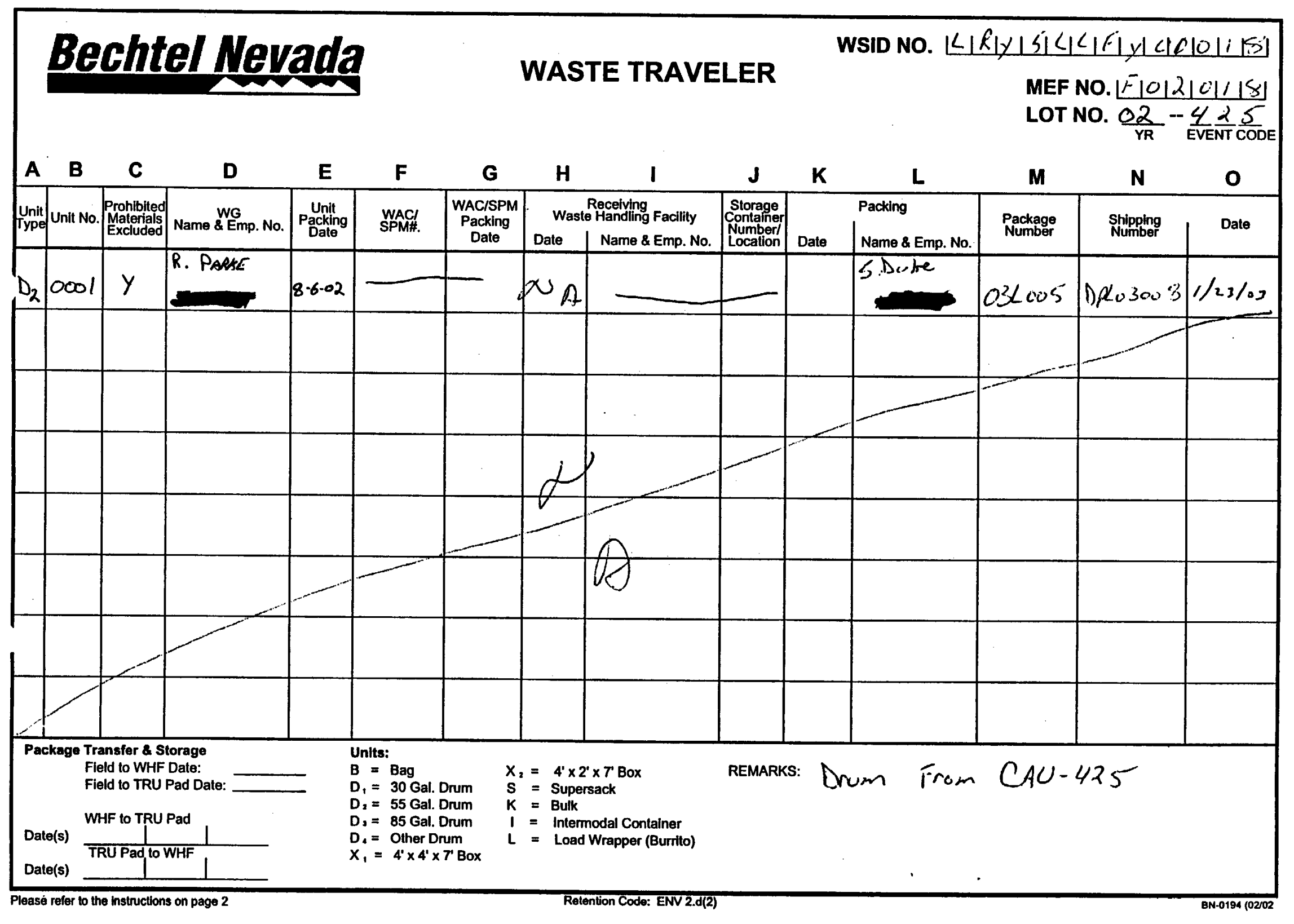




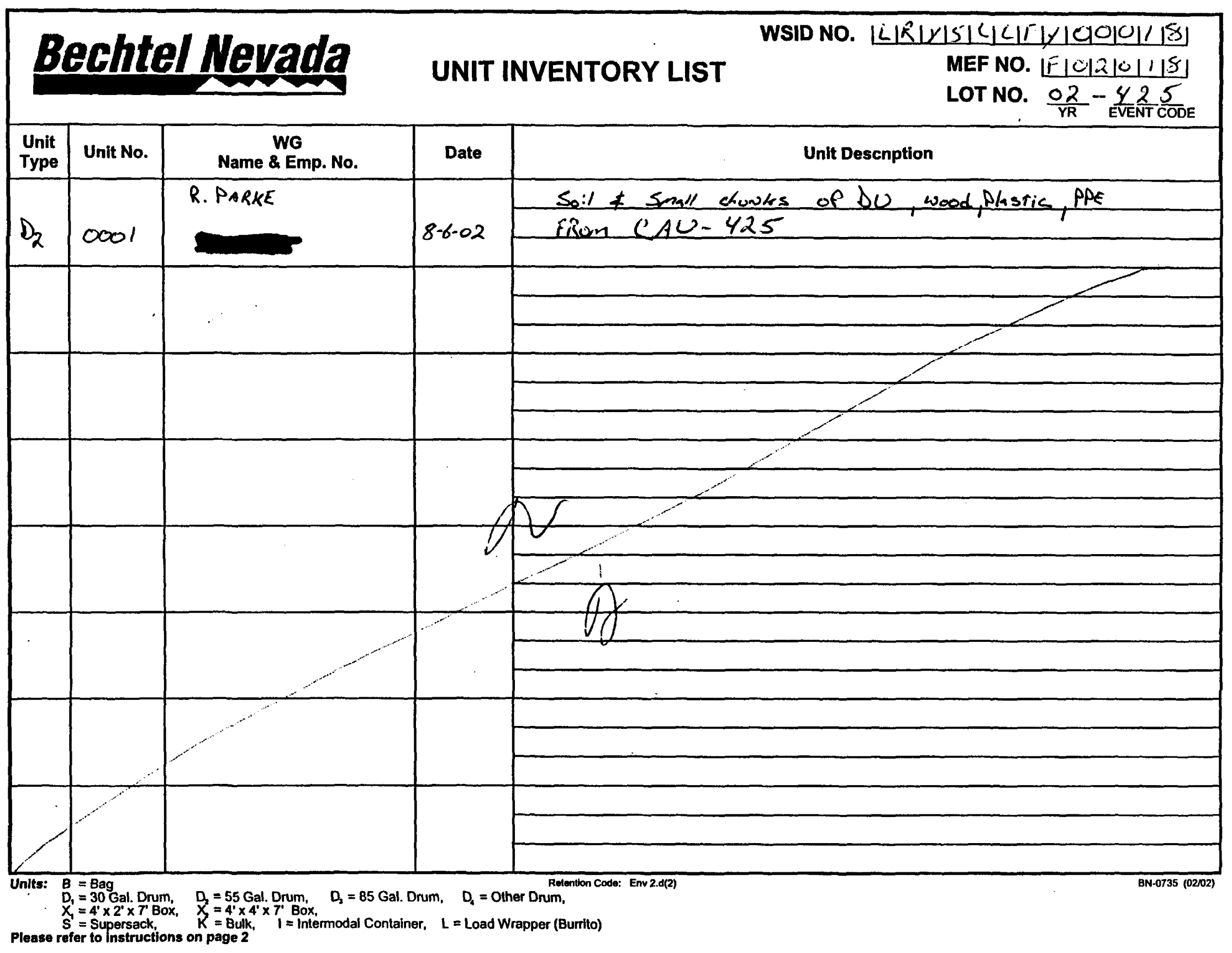


CLOSURE REPORT - CAU 425

Section: Appendix E

Revision: 0

Date: February 2003

\section{APPENDIX E}

\section{PHOTOGRAPHS OF CLOSURE ACTIVITIES}


CLOSURE REPORT - CAU 425

Section: Appendix E

Revision: 0

Date: February 2003

THIS PAGE INTENTIONALLY LEFT BLANK 


\section{PHOTOGRAPH LOG}

\begin{tabular}{|c|c|l|}
\hline $\begin{array}{c}\text { PHOTOGRAPH } \\
\text { NUMBER }\end{array}$ & DATE & \multicolumn{1}{|c|}{ DESCRIPTION } \\
\hline 1 & $07 / 17 / 2002$ & $\begin{array}{l}\text { Overview of CAU 425 Area 9 Main Lake } \\
\text { Construction Debris Disposal Area. }\end{array}$ \\
\hline 2 & $07 / 11 / 2002$ & $\begin{array}{l}\text { RCT performing radiological field screening of } \\
\text { debris prior to loading for transport and disposal. }\end{array}$ \\
\hline 3 & $07 / 11 / 2002$ & $\begin{array}{l}\text { Removal of construction debris using a front-end } \\
\text { loader. }\end{array}$ \\
\hline 4 & $07 / 17 / 2002$ & $\begin{array}{l}\text { Close up of the discovery and location of the } \\
\text { Depleted Uranium. }\end{array}$ \\
\hline
\end{tabular}


CLOSURE REPORT - CAU 425

Section: Appendix E

Revision: 0

Date: February 2003

THIS PAGE INTENTIONALLY LEFT BLANK

E-2 


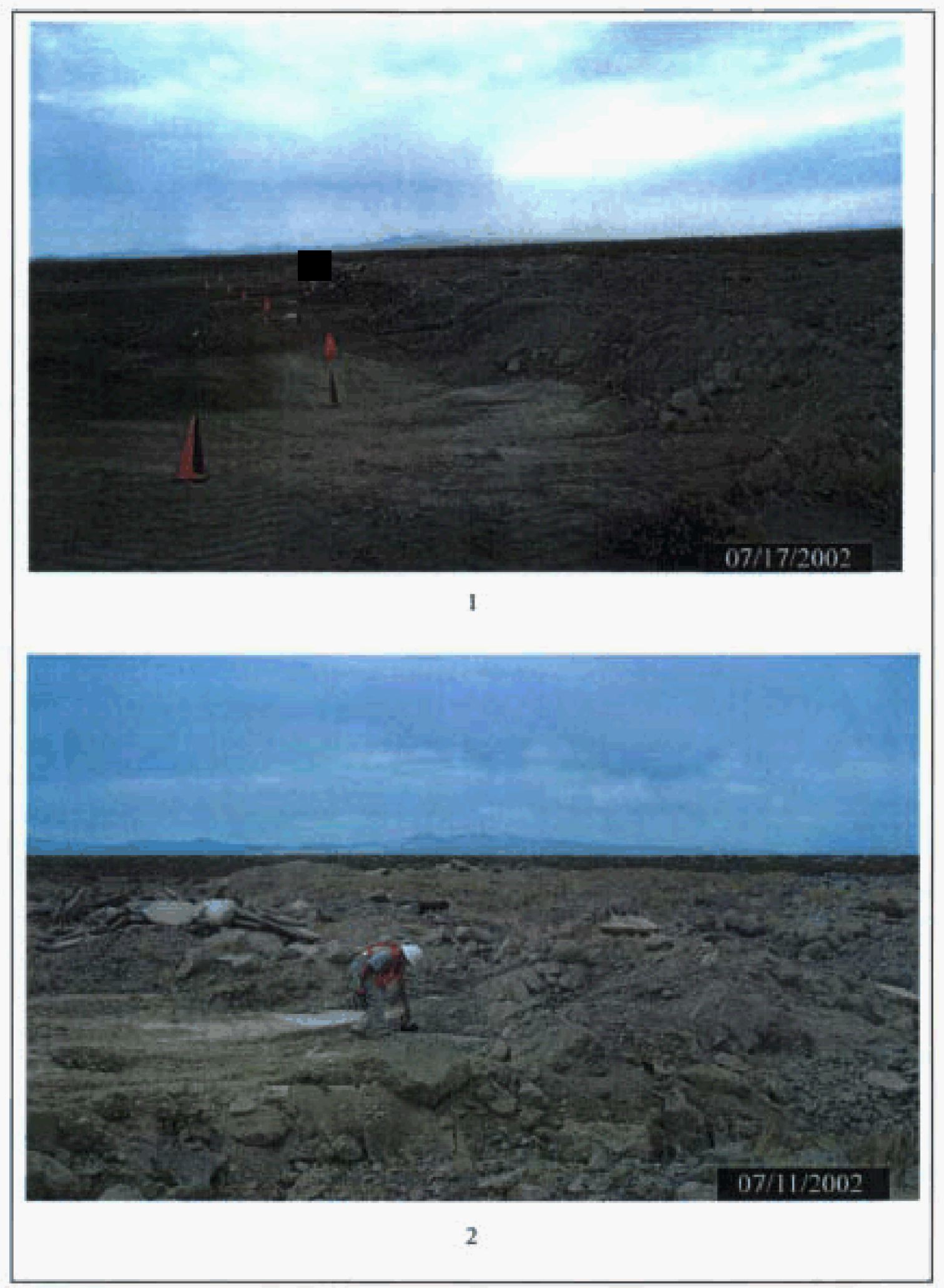

E-3 


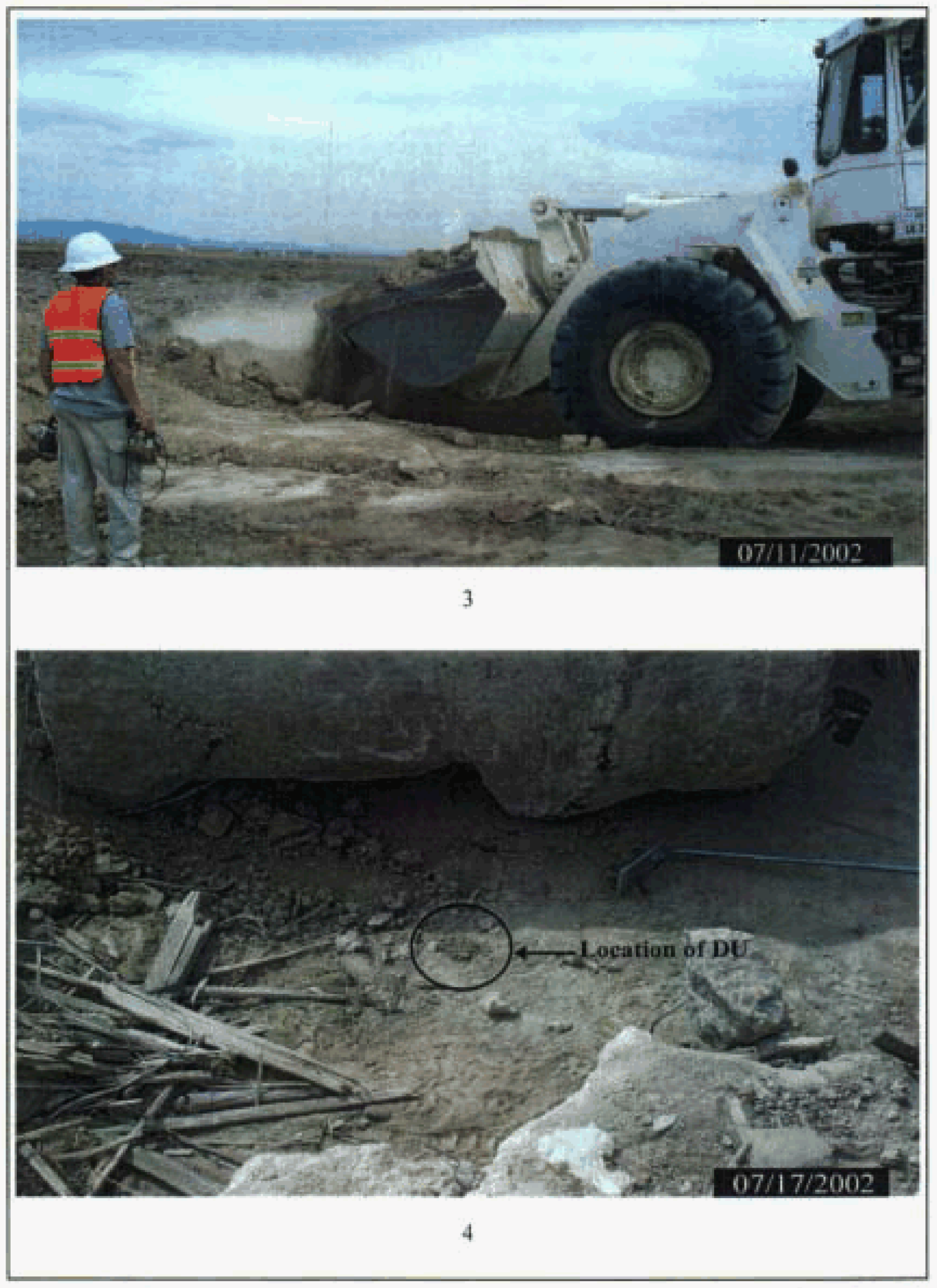

E-4 
CLOSURE REPORT - CAU 425

Section: Appendix $F$

Revision: 0

Date: February 2003

\section{APPENDIX F}

\section{NEVADA DIVISION OF ENVIRONMENTAL PROTECTION DOCUMENT REVIEW SHEET}


CLOSURE REPORT - CAU 425

Section: Appendix F

Revision: 0

Date: February 2003

THIS PAGE INTENTIONALLY LEFT BLANK 


\section{NEVADA ENVIRONMENTAL RESTORATION PROJECT DOCUMENT REVIEW SHEET}

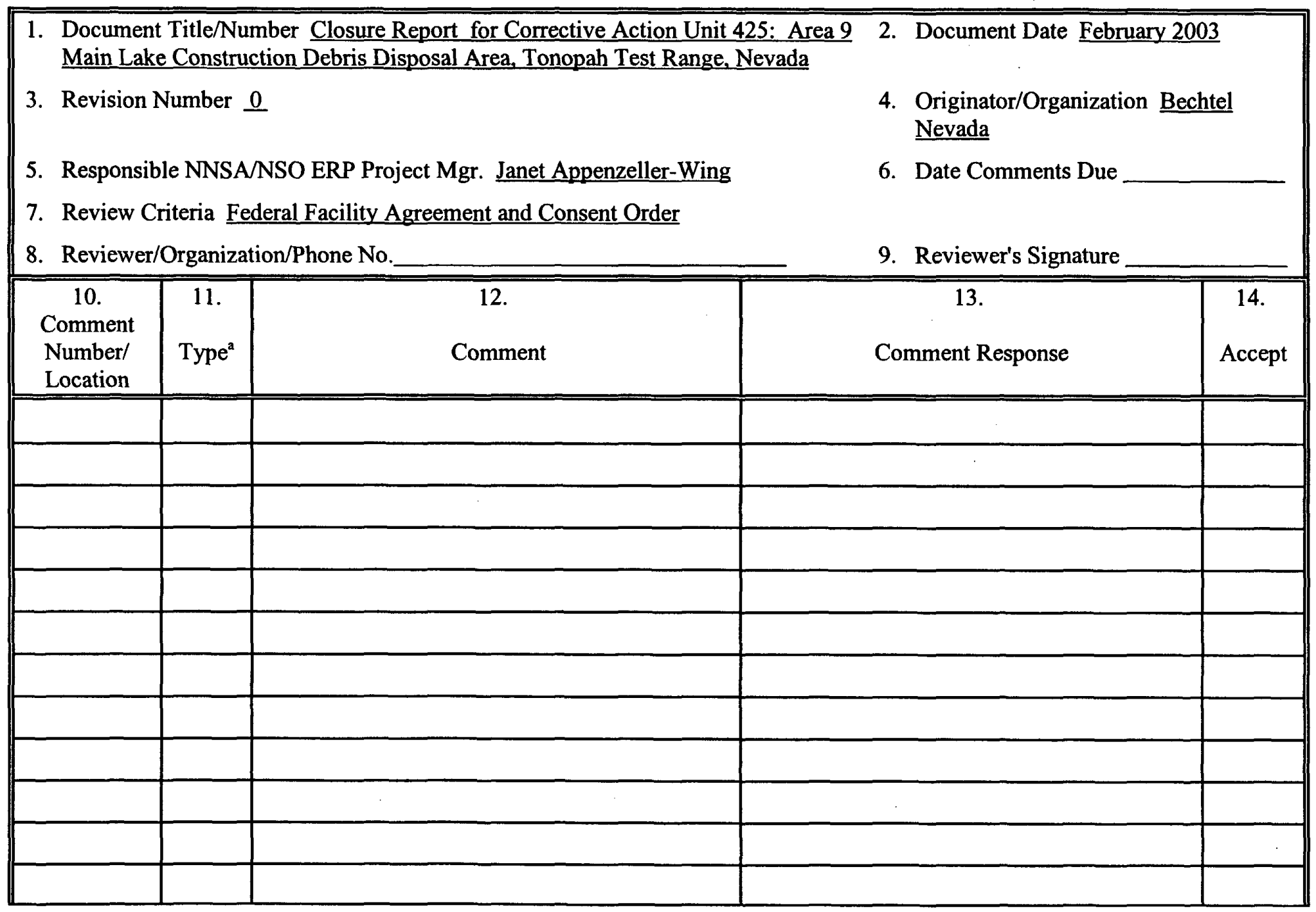

acomment Types: $M=$ Mandatory, $S=$ Suggested. 
Page 2 of 2

\begin{tabular}{|c|c|c|c|c|}
\hline $\begin{array}{c}10 . \\
\text { Comment } \\
\text { Number/ } \\
\text { Location }\end{array}$ & $\begin{array}{c}11 . \\
\text { Type }^{\mathrm{a}}\end{array}$ & $\begin{array}{c}12 . \\
\text { Comment }\end{array}$ & $\begin{array}{c}13 . \\
\text { Comment Response }\end{array}$ & $\begin{array}{c}14 . \\
\text { Accept }\end{array}$ \\
\hline & & & & \\
\hline & & & & \\
\hline & & & & \\
\hline & & & & \\
\hline & & & & \\
\hline & & & & \\
\hline & & & & \\
\hline & & & & \\
\hline & & & & \\
\hline & & & & \\
\hline & & & & \\
\hline & & & & \\
\hline & & & & \\
\hline
\end{tabular}


CLOSURE REPORT - CAU 425

Section: Distribution List

Revision: 0

Date: February 2003

\section{DISTRIBUTION LIST}


CLOSURE REPORT - CAU 425

Section: Distribution List

Revision: 0

Date: February 2003

THIS PAGE INTENTIONALLY LEFT BLANK 


\section{DISTRIBUTION LIST}

*Provide copy of initial distribution of all revisions; others receive NDEP-approved revision only.

\section{Nevada Division of Environmental Protection}

Paul Liebendorfer

1 (Controlled)*

Bureau of Federal Facilities

Division of Environmental Protection

333 W. Nye Lane, Room 138

Carson City, NV 89706-0866

Donald Elle

1 (Controlled)*

Bureau of Federal Facilities

Division of Environmental Protection

1771 E. Flamingo Rd., Suite 121-A

Las Vegas, NV 89119-0837

\section{U.S. Department of Energy}

Janet Appenzeller-Wing

Environmental Restoration Division

1 (Uncontrolled)*

U.S. Department of Energy

National Nuclear Security Administration

Nevada Site Office

P.O. Box 98518 , M/S 505

Las Vegas, NV 89193-8518

Kevin Cabble

Environmental Restoration Division

1 (Uncontrolled)*

U.S. Department of Energy

National Nuclear Security Administration

Nevada Site Office

P.O. Box 98518 , M/S 505

Las Vegas, NV 89193-8518

Sabrina Lawrence

1 (Controlled)*

Environmental Restoration Division

U.S. Department of Energy

National Nuclear Security Administration

Nevada Site Office

P.O. Box 98518, M/S 505

Las Vegas, NV 89193-8518 


\section{DISTRIBUTION LIST (continued)}

\section{U.S. Department of Energy (continued)}

Manager, Southern Nevada FFACO

1 (Controlled) \&

Public Reading Facility

P.O. Box $98521 \mathrm{M} / \mathrm{S}$ CF040

1 (Uncontrolled)

Las Vegas, NV 89193-8521

U.S. Department of Energy

1 (Uncontrolled)

National Nuclear Security Administration

Nevada Site Office

Technical Library

P.O. Box 98521, M/S 505

Las Vegas, NV 89193-8521

U.S. Department of Energy

Office of Scientific and Technical Information

1 (Electronic)

175 Oak Ridge Turnpike

P.O. Box 62

Oak Ridge, TN 37831-0062

\section{Bechtel Nevada}

Correspondence Control

Bechtel Nevada

P.O. Box 98521 , M/S CF008

Las Vegas, NV 89193-8521

Environmental Management Library

1 (Uncontrolled)*

Bechtel Nevada

P.O. Box 98521, M/S NLV080

Las Vegas, NV 89193-8521

Kevin Campbell

1 (Uncontrolled)*

Bechtel Nevada

P.O. Box 98521, M/S NTS306

Las Vegas, NV 89193-8521

Tom Fitzmaurice

1 (Uncontrolled)*

Bechtel Nevada

P.O. Box 98521, M/S NTS306

Las Vegas, NV 89193-8521 
DISTRIBUTION LIST (continued)

Brad Jackson

1 (Uncontrolled)*

Bechtel Nevada

P.O. Box 98521, M/S NTS306

Las Vegas, NV 89193-8521

Wayne Johnson

1 (Uncontrolled)*

Bechtel Nevada

P.O. Box $98521 \mathrm{M} / \mathrm{S}$ NLV080

Las Vegas, NV 89193-8521

Michael Kruzic

1 (Uncontrolled)*

Bechtel Nevada

P.O. Box 98521, M/S NTS306

Las Vegas, NV 89193-8521

Steve Nacht

1 (Uncontrolled)*

Bechtel Nevada

P.O. Box $98521, \mathrm{M} / \mathrm{S}$ NTS306

Las Vegas, NV 89193-8521

International Technology Corporation

Lynn Kidman

1 (Uncontrolled)*

IT Corp.

P.O. Box 93838, M/S 439

Las Vegas, NV 89193-8521

FFACO coordinator

1 (Controlled)

IT Corp.

P.O. Box $93838, \mathrm{M} / \mathrm{S} 439$

Las Vegas, NV 89193-8521

State of Nevada

Manager, Northern Nevada FFACO

1 (Controlled)

FFACO Public Reading Facility

Nevada State Library and Archives Federal Publications

100 North Stewart Street

Carson City, NV 89701-4285 


\section{DISTRIBUTION LIST (continued)}

\section{U.S. Air Force}

Air Warfare Center

1 (Uncontrolled)*

3770 Duffer Drive

Nellis AFB, NV 89191

Lt. Colonel Richard M. Scarine

1(Uncontrolled)*

Northern Range Commander

Det 2 (RMO)

3770 Duffer drive

Nellis AFB, NV 89191

Gerald Carpenter

U.S. Air Force DOE Liaison Office

1 (Uncontrolled)*

DOE/Nevada Site Office

P.O. Box 98518, MS 505

Las Vegas, NV 89193-8518

Eloisa V. Hopper

3 (Controlled)*

$99 \mathrm{ABW} / \mathrm{EM}$

4349 Duffer Drive, Suite 1601

Nellis AFB, NV 89191-7007

\section{Sandia National Laboratories}

Vern Gabbard

1 (Uncontrolled)*

Sandia National Laboratories, Tonopah Test Range

Box 871

Tonopah, NV 89049 